\title{
Feeding a Molecular Squid. A Pliable Nanocarbon Receptor for Electron-Poor Aromatics
}

\author{
Supplementary Information
}

by Rafał Frydrych, Tadeusz Lis, Wojciech Bury, Joanna Cybińska, and Marcin Stępień*

\section{Table of Contents}

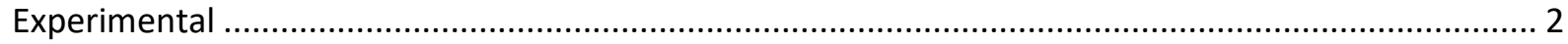

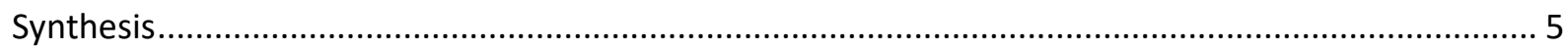

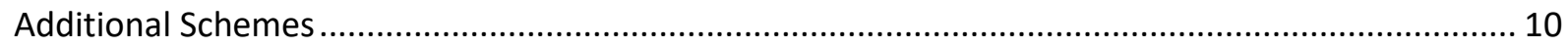

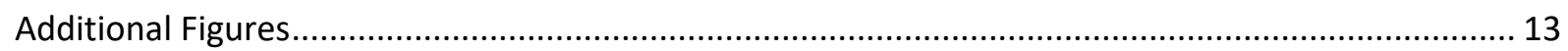

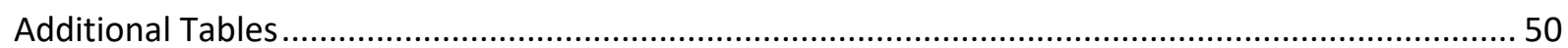

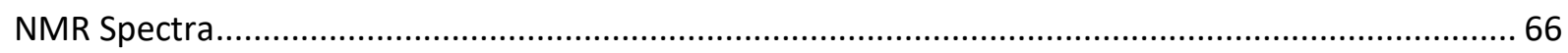

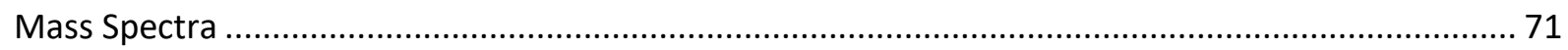

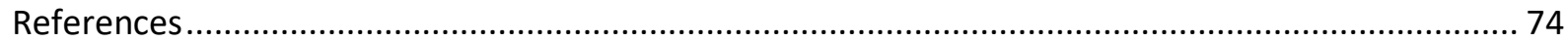


Experimental 
General. Tetrahydrofuran, toluene, 1,4-dioxane and N,N-Dimethylformamide were freeze-pumpthawed prior to use. All other solvents and reagents were used as received. Compounds S1, S2, S3, S4 and $2 \mathrm{a}$ were prepared according to modified literature procedures. ${ }^{1-5}{ }^{1} \mathrm{H}$ NMR spectra were recorded on high-field spectrometers ( ${ }^{1} \mathrm{H}$ frequency 500.13 or $600.13 \mathrm{MHz}$ ), equipped with broadband inverse or conventional gradient probeheads. Spectra were referenced to the residual solvent signals (chloroform- $d, 7.26 \mathrm{ppm}$, dichloromethane- $d_{2}, 5.32 \mathrm{ppm}$, acetone- $d_{6}, 2.05$ ). Two-dimensional NMR spectra were recorded with 2048 data points in the $t_{2}$ domain and up to 2048 points in the $t_{1}$ domain, with a $1.5 \mathrm{~s}$ recovery delay. All 2D spectra were recorded with gradient selection, with the exception of ROESY. ${ }^{13} \mathrm{C}$ NMR spectra were recorded with ${ }^{1} \mathrm{H}$ broadband decoupling and referenced to solvent signals $\left({ }^{13} \mathrm{CDCl}_{3}, 77.0 \mathrm{ppm}\right)$. High resolution mass spectra were recorded using ESI ionization in the positive mode on Bruker Apex ultra FT-ICR. Absorption spectrometry was performed using Agilent Cary 60 UV-Vis spectrophotometer. Recycling gel permeation chromatography (GPC) was carried out using an JAI LaboACE LC-7080 chromatograph equipped with a RID (RI-700 LA) and UV-Vis (UV-VIS4ch 800LA) detectors and a preparative GPC columns JAIGEL-2HR and JAIGEL-2.5HR (size $20.0 \mathrm{~mm} \mathrm{ID} \times 600 \mathrm{~mm}$ each) in series, using chloroform as an eluent with a flow rate of $10 \mathrm{~mL} / \mathrm{min}$ at $30^{\circ} \mathrm{C}$.

${ }^{1} \mathrm{H}$ NMR spectroscopic titration studies. ${ }^{6,7}$ The receptor solutions of 1 (1.81 or $0.906 \mathrm{mM}$, acetone- $d_{6}$ or $\mathrm{CD}_{2} \mathrm{Cl}_{2}, 300 \mathrm{~K}$ ) were titrated in an $\mathrm{NMR}$ tube sealed with a plastic stopper, by adding known quantities of a stock solution of either $\left[\mathrm{DQ}^{2+}\right]\left[\mathrm{PF}_{6}^{-}\right]_{2},\left[\mathrm{PQ}^{2+}\right]\left[\mathrm{PF}_{6}^{-}\right]_{2},\left[\mathrm{MA}^{+}\right]\left[\mathrm{PF}_{6}^{-}\right]$or $\mathrm{AQ}$ in the same solvent. These solutions contained compound 1 to ensure a constant concentration of the guest throughout the titration. After each addition the NMR tube was quickly shaken to ensure good mixing of the solutions and after temperature stabilization the spectra were recorded. [AQ] was purchased from Sigma-Aldrich. $\left[\mathrm{DQ}^{2+}\right]\left[\mathrm{PF}_{6}^{-}\right]_{2},\left[\mathrm{PQ}^{2+}\right]\left[\mathrm{PF}_{6}^{-}\right]_{2},\left[\mathrm{MA}^{+}\right]\left[\mathrm{PF}_{6}^{-}\right]$were prepared according to modified literature procedures ${ }^{8-10}$ The fitting, performed with the Bindfit software, ${ }^{11}$ takes into account all data sets at the same time, thus improving the quality of the non-linear curve fitting. The data for $\left[\mathrm{DQ}^{2+}\right]\left[\mathrm{PF}_{6}^{-}\right]_{2},\left[\mathrm{PQ}^{2+}\right]\left[\mathrm{PF}_{6}{ }^{-}\right]_{2}$ and $\left[\mathrm{MA}^{+}\right]\left[\mathrm{PF}_{6}^{-}\right]$were fitted to the 1:1 and 2:1 (1:G) binding model, 1 being the receptor and $G$ the guest molecule. The data obtained for $A Q$ were fitted to the 1:1 binding model only.

Gas and Vapor Sorption Analyses. All gas and vapor sorption isotherms were measured on a Micromeritics ASAP 2020M surface area and porosimetry system. Prior to the measurements, the sample of 1 was recrystallized from the benzene/methanol solvent mixture. The precipitate was filtered off and degassed at $50{ }^{\circ} \mathrm{C}$ for $24 \mathrm{~h} . \mathrm{N}_{2}$ sorption measurements were performed at $77 \mathrm{~K}$ using a liquid $\mathrm{N}_{2}$ bath. For the $\mathrm{CO}_{2}$ measurement carried out at $195 \mathrm{~K}$, an isopropanol/dry ice cooling bath was used. For all other measurements $\left(\mathrm{CO}_{2}\right.$, cyclohexane, $\mathrm{MeOH}$, water) carried out in the 273-293 K temperature range, chilled water/ethylene glycol bath was used for temperature control. All gases used were of $99.999 \%$ purity. Helium was used for the free-space determination. The isosteric heats of adsorption $\left(Q_{\mathrm{st}}\right)$ were calculated by fitting the $\mathrm{CO}_{2}$ adsorption isotherms using the single-site Langmuir-Freundlich model ( 1 ) and $Q_{s t}$ was calculated using the Clausius-Clapeyron equation

$$
q=\frac{q_{s a t} K p^{n}}{1+K p^{n}}
$$

where $q$ is the gravimetric uptake of $\mathrm{CO}_{2}(\mathrm{mmol} / \mathrm{g})$ at pressure $p . q_{\text {sat }}, K$ and $n$ are the saturation loading and the Langmuir-Freundlich constants, respectively.

Excitation and emission spectra were obtained using a FLS980 spectrofluorimeter (Edinburgh Instruments Ltd.) equipped with a $450 \mathrm{~W}$ Xenon lamp excitation source and a red-sensitive 
photomultiplier (Hamamatsu R-928P) operating within 200-870 nm. The former spectra were corrected for the incident light intensity and the latter for the wavelength-dependence of the emission channel sensitivity. Quantum yields were measured using a cooled extended-red Hamamatsu photomultiplier operating in a range of $200-1050 \mathrm{~nm}$. Quantum yield measurements were performed by using an Edinburgh Instruments integrating sphere equipped with a small elliptical mirror and a baffle plate for beam steering and shielding against directly detected light. For the measurement, the integrating sphere replaces the standard sample holder inside the sample chamber. Calculations of quantum yields were made using the software provided by Edinburgh Instruments. The luminescence decay traces were registered by means of F-G05PM featuring a Hamamatsu H5773-04 detector. As an excitation source picosecond pulsed light emitting diode $360 \mathrm{~nm}$ was used.

Computational methods. Tight-binding density functional theory calculations were performed using XTB v. 6.1 with the GFN2 parameterization, and the GBSA solvation model as necassary. ${ }^{12-14}$ CREST $^{12}$ metadynamics searches were performed using default parameters. Density functional theory (DFT) calculations were performed using Gaussian $16 .{ }^{15}$ DFT geometry optimizations were carried out in unconstrained $C_{1}$ symmetry, typically using the entire CREST ensemble and selecting the conformer with lowest DFT Gibbs free energy. DFT geometries were refined to meet standard convergence criteria, and the existence of a local minimum was verified by a normal mode frequency calculation. Geometry optimizations, frequency calculations were performed using the hybrid functional B3LYP ${ }^{16-}$ ${ }^{18}$ and the $6-31 G(d, p)$ basis set and Grimme's GD3BJ dispersion correction. ${ }^{19}$ The CAM modification was employed as discussed in the manuscript.

X-ray crystallography. X-ray quality crystals were grown as follows: $\mathbf{5} \cdot \mathrm{C}_{6} \mathrm{H}_{14} \cdot \mathrm{H}_{2} \mathrm{O}$ by slow diffusion of $n$ hexane into ethyl acetate, $1 \cdot 3 \mathrm{C}_{6} \mathrm{H}_{6}$ by slow diffusion of methanol into benzene, $1 \cdot 3.2 \mathrm{CH}_{2} \mathrm{Cl}_{2}$ by slow diffusion of methanol into dichloromethane, [1 $\mathrm{AAQ} \cdot 2.5 \mathrm{CH}_{4} \mathrm{O}$ by slow diffusion of methanol into a

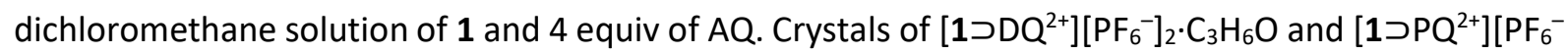
]$_{2} \cdot \mathrm{C}_{3} \mathrm{H}_{6} \mathrm{O}$ were obtained from crystals of $1 \cdot 3 \mathrm{C}_{6} \mathrm{H}_{6}$, which were placed in an acetone-methanol solution of $\left[\mathrm{DQ}^{2+}\right]\left[\mathrm{PF}_{6}^{-}\right]_{2}$ or $\left[\mathrm{PQ}^{2+}\right]\left[\mathrm{PF}_{6}^{-}\right]_{2}$, respectively. These samples were kept in the presence of methanol vapors until the crystal-to-crystal transformation was complete. Diffraction measurements were performed on a k-geometry Ruby PX diffractometer ( $\omega$ scans) with graphite-monochromatized Mo K $\alpha$ or $\mathrm{Cu} \mathrm{K} \alpha$ radiation. The data were collected at $100 \mathrm{~K}$, corrected for Lorenz and polarization effects. Data collection, cell refinement, data reduction and analysis were carried out with the Xcalibur PX software, CRYSALIS CCD and CRYSALIS RED, respectively (Oxford Diffraction Ltd., Abignon, England, 2009). An analytical absorption correction was applied with the use of CRYSALIS RED. All structures were solved by direct methods with the SHELXS-97 program and refined using SHELXL-97 with anisotropic thermal parameters for non- $\mathrm{H}$ atoms. In the final refinement cycles, all $\mathrm{H}$ atoms were treated as riding atoms in geometrically optimized positions. CCDC $2016786\left(\mathbf{1} \cdot 3 \mathrm{C}_{6} \mathrm{H}_{6}\right), 2016787$ $\left(5 \cdot \mathrm{C}_{6} \mathrm{H}_{14} \cdot \mathrm{H}_{2} \mathrm{O}\right), 2016788\left(\mathbf{1} \cdot 3.2 \mathrm{CH}_{2} \mathrm{Cl}_{2}\right), 2016789\left(\left[1 \supset \mathrm{PQ}^{2+}\right]\left[\mathrm{PF}_{6}{ }^{-}\right]_{2} \cdot \mathrm{C}_{3} \mathrm{H}_{6} \mathrm{O}\right), 2016790\left([1 \supset \mathrm{AQ}] \cdot 2.5 \mathrm{CH}_{4} \mathrm{O}\right)$, and $2016791\left(\left[1 \mathrm{DDQ}^{2+}\right]\left[\mathrm{PF}_{6}{ }^{-}\right]_{2} \cdot \mathrm{C}_{3} \mathrm{H}_{6} \mathrm{O}\right)$ contain the supplementary crystallographic data for this paper. These data are provided free of charge by The Cambridge Crystallographic Data Centre via www.ccdc.cam.ac.uk/data_request/cif. 
Synthesis 

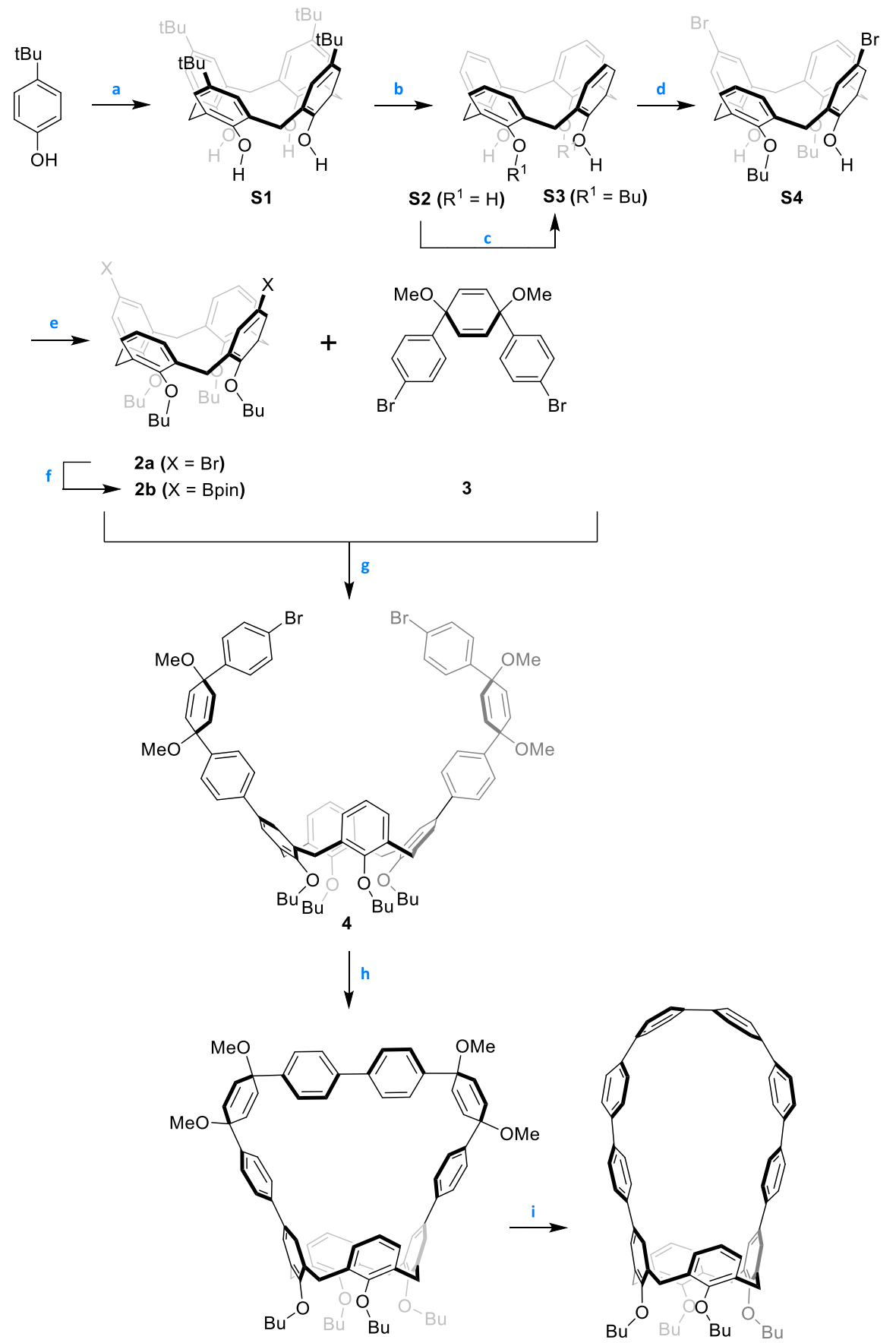

1

Scheme S1. Synthesis of compound 1: (a) $37 \%$ solution of formaldehyde in water, $\mathrm{NaOH}, \mathrm{Ph}_{2} \mathrm{O}$, reflux; (b) $\mathrm{AlCl}_{3}$, toluene; (c) $\mathrm{BuBr}, \mathrm{K}_{2} \mathrm{CO}_{3}$, reflux; (d) $\mathrm{Br}_{2}, \mathrm{CHCl}_{3}, 0^{\circ} \mathrm{C}$; (e) $\mathrm{BuBr}$, NaH, reflux, $0{ }^{\circ} \mathrm{C}$ to $\mathrm{RT}$; (f) $\mathrm{Pd}(\mathrm{dppf}) \mathrm{Cl}_{2}$, [B(pin) $]_{2}, \mathrm{CH}_{3} \mathrm{COOK}$, dioxane, $110^{\circ} \mathrm{C}, 12 \mathrm{~h}$; (g) $\mathrm{Pd}(\mathrm{OAc})_{2}$, dppf, $\mathrm{Ag}_{2} \mathrm{O}, \mathrm{K}_{2} \mathrm{CO}_{3}$, toluene, water, $80{ }^{\circ} \mathrm{C}, 24 \mathrm{~h}$; (h) Ni(cod) 2, bpy, THF, DMF, $80{ }^{\circ} \mathrm{C}, 16 \mathrm{~h}$; (i) $\mathrm{H}_{2} \mathrm{SnCl}_{4}$, THF, RT, overnight. 


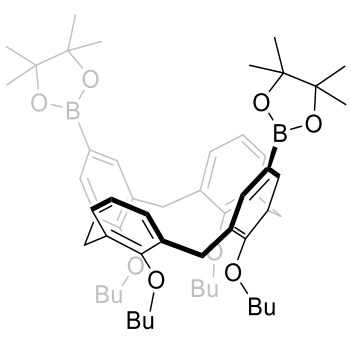

$2,2^{\prime}-\left(1^{2}, 3^{2}, 5^{2}, 7^{2}\right.$-Tetrabutoxy-1,3,5,7(1,3)-tetrabenzenacyclooctaphane- $1^{5}, 5^{5}$-diyl)bis $(4,4,5,5-$

tetramethyl-1,3,2-dioxaborolane) (2b). Inside the glove box, compound $2 \mathrm{a}(0.700 \mathrm{~g}, 0.868 \mathrm{mmol}, 1.0$ equiv), bis(pinacolato)diboron ( $0.529 \mathrm{~g}, 2.08 \mathrm{mmol}, 2.4$ equiv), $\mathrm{Pd}(\mathrm{dppf}) \mathrm{Cl}_{2}$ ( $34.43 \mathrm{mg}, 0.43 \mathrm{mmol}, 0.05$ equiv) and potassium acetate $(0.204 \mathrm{~g}, 2.08 \mathrm{mmol}, 2.4$ equiv) were dissolved in 1,4-dioxane $(14 \mathrm{~mL})$ in a pressure tube equipped with a stir bar. The tube was sealed with a cap, transferred out of the glove box and stirred at $110^{\circ} \mathrm{C}$ for $12 \mathrm{~h}$. The reaction mixture was cooled to room temperature, brine was added, followed by extraction with dichloromethane. Combined organic layers were dried over sodium sulfate and evaporated under reduced pressure. The product was purified by column chromatography (silica, dichloromethane/hexane, 3:1) (0.651 g, 83\%). ${ }^{1} \mathrm{H}$ NMR (500 MHz, chloroform- $\left.d, 300 \mathrm{~K}\right): \delta 7.60$ $(4 \mathrm{H}, \mathrm{s}), 6.19\left(2 \mathrm{H}, \mathrm{t},{ }^{3} \mathrm{~J}=7.6 \mathrm{~Hz}\right), 6.10\left(4 \mathrm{H}, \mathrm{d},{ }^{3} \mathrm{~J}=7.6 \mathrm{~Hz}\right), 4.42\left(4 \mathrm{H}, \mathrm{d},{ }^{2} \mathrm{~J}=13.3 \mathrm{~Hz}\right), 4.12\left(4 \mathrm{H}, \mathrm{t},{ }^{3} \mathrm{~J}=8.3\right.$ $\mathrm{Hz}), 3.69\left(4 \mathrm{H}, \mathrm{t},{ }^{3} J=6.5 \mathrm{~Hz}\right), 3.20\left(4 \mathrm{H}, \mathrm{d},{ }^{2} J=13.4 \mathrm{~Hz}\right), 1.90\left(4 \mathrm{H}\right.$, quint, $\left.{ }^{3} J=8.1 \mathrm{~Hz}\right), 1.84\left(4 \mathrm{H}\right.$, quint, ${ }^{3} J=$ $7.1 \mathrm{~Hz}) 1.61\left(4 \mathrm{H}\right.$, sextet, $\left.{ }^{3} \mathrm{~J}=7.5 \mathrm{~Hz}\right), 1.39(24 \mathrm{H}, \mathrm{s}) 1.26\left(4 \mathrm{H}\right.$, sextet, $\left.{ }^{3} \mathrm{~J}=7.5 \mathrm{~Hz}\right), 1.00\left(6 \mathrm{H}, \mathrm{t},{ }^{3} \mathrm{~J}=7.4 \mathrm{~Hz}\right)$, $0.96\left(6 \mathrm{H}, \mathrm{t},{ }^{3} \mathrm{~J}=7.4 \mathrm{~Hz}\right) .{ }^{13} \mathrm{C}$ NMR $(125 \mathrm{MHz}$, chloroform- $d, 300 \mathrm{~K}): \delta 161.2,155.1,136.7,135.7,133.0$, $127.5,122.0,83.5,74.9,74.7,32.6,32.0,30.8,25.0,19.6,19.0,14.1,13.9$. HRMS (ESI-TOF): $m / z:$ [M $+\mathrm{Na}]^{+}$Calcd for $\mathrm{C}_{56} \mathrm{H}_{78} \mathrm{~B}_{2} \mathrm{O}_{8} \mathrm{Na}^{+}:$923.5793; Found 923.5731 .

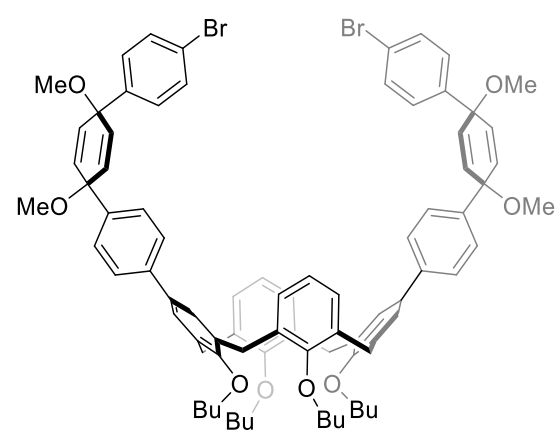

$1^{5}, 5^{5}$-bis(4"-bromo-1',4'-dimethoxy-1',4'-dihydro-[1,1':4',1"-terphenyl]-4-yl)-1 2 $^{2}, 3^{2}, 5^{2}, 7^{2}$ -

tetrabutoxy-1,3,5,7(1,3)-tetrabenzenacyclooctaphane (4). Inside the glove box, $\operatorname{Pd}(\mathrm{OAc})_{2}(14.95 \mathrm{mg}$, $0.066 \mathrm{mmol}, 0.12$ equiv), dppf ( $41.54 \mathrm{mg}, 0.075 \mathrm{mmol}, 0.135$ equiv) and anhydrous toluene $(4 \mathrm{~mL})$ were added to a $5 \mathrm{~mL}$ vial equipped with a stir bar. The mixture was stirred in the glove box at room temperature for $30 \mathrm{~min}$. Then it was added to a pressure tube containing a solution of compound $\mathbf{2 b}$ (0.500 g, $0.55 \mathrm{mmol}, 1.0$ equiv), 3 (1.999 g, $4.44 \mathrm{mmol}, 8.0$ equiv), $\mathrm{K}_{2} \mathrm{CO}_{3}(0.153 \mathrm{~g}, 1.11 \mathrm{mmol}, 2.0$ equiv), and $\mathrm{Ag}_{2} \mathrm{O}$ (0.579 g, $1.33 \mathrm{mmol}, 4.5$ equiv) in $36 \mathrm{~mL}$ of anhydrous toluene. The pressure tube was sealed with a septum cap and transferred out of the glove box. Degassed water $(4 \mathrm{~mL})$ was added through the septum via a syringe, and the septum cap was replaced with the pressure bushing under a blanket of argon. The reaction mixture was stirred at $80^{\circ} \mathrm{C}$ in an oil bath for $24 \mathrm{~h}$, cooled down to room temperature, and filtered through celite. The solvent was removed under reduced pressure. Excess of the substrate $\mathbf{3}$ was removed from the mixture by column chromatography (basic alumina 
grade III, dichloromethane/hexane/ethyl acetate, 1:2:0.01). The crude product was dissolved in dichloromethane, loaded on alumina by slow evaporation, and purified by column chromatography (basic alumina grade III, 15\% ethyl acetate in hexane) to get compound 4 (0.451 g, 59\%). ${ }^{1} \mathbf{H}$ NMR (600 $\mathrm{MHz}$, chloroform-d , $300 \mathrm{~K}): \delta 7.55\left(4 \mathrm{H}, \mathrm{d},{ }^{3} J=8.3 \mathrm{~Hz}\right), 7.46\left(4 \mathrm{H}, \mathrm{d},{ }^{3} J=8.5 \mathrm{~Hz}\right), 7.41\left(4 \mathrm{H}, \mathrm{d},{ }^{3} \mathrm{~J}=8.3 \mathrm{~Hz}\right)$, $7.31\left(4 \mathrm{H}, \mathrm{d},{ }^{3} \mathrm{~J}=8.5 \mathrm{~Hz}\right), 7.27(4 \mathrm{H}, \mathrm{s}), 6.26(6 \mathrm{H}, \mathrm{m}), 6.19\left(4 \mathrm{H}, \mathrm{d},{ }^{3} \mathrm{~J}=10.2 \mathrm{~Hz}\right), 6.07\left(4 \mathrm{H}, \mathrm{d},{ }^{3} \mathrm{~J}=10.2 \mathrm{~Hz}\right)$, $4.50\left(4 \mathrm{H}, \mathrm{d},{ }^{2} J=13.2 \mathrm{~Hz}\right), 4.09\left(4 \mathrm{H}, \mathrm{t},{ }^{3} J=8.1 \mathrm{~Hz}\right), 3.77\left(4 \mathrm{H}, \mathrm{t},{ }^{3} J=6.7 \mathrm{~Hz}\right), 3.45(6 \mathrm{H}, \mathrm{s}), 3.44(6 \mathrm{H}, \mathrm{s}), 3.22$ $\left(4 \mathrm{H}, \mathrm{d},{ }^{2} J=13.3 \mathrm{~Hz}\right), 1.97\left(4 \mathrm{H}\right.$, quint, $\left.{ }^{3} \mathrm{~J}=7.9 \mathrm{~Hz}\right), 1.89\left(4 \mathrm{H}\right.$, quint, $\left.{ }^{3} \mathrm{~J}=7.2 \mathrm{~Hz}\right), 1.60\left(4 \mathrm{H}\right.$, sextet, ${ }^{3} \mathrm{~J}=7.5$ $\mathrm{Hz}), 1.35\left(4 \mathrm{H}\right.$, sextet, $\left.{ }^{3} \mathrm{~J}=7.5 \mathrm{~Hz}\right), 1.04\left(6 \mathrm{H}, \mathrm{t},{ }^{3} \mathrm{~J}=7.3 \mathrm{~Hz}\right), 1.00\left(6 \mathrm{H}, \mathrm{t},{ }^{3} \mathrm{~J}=7.3 \mathrm{~Hz}\right) .{ }^{13} \mathrm{C}$ NMR $(151 \mathrm{MHz}$, chloroform-d , $300 \mathrm{~K}): \delta 157.6,155.5,142.7,141.4,140.6,137.0,134.0,133.9,133.3,132.8,131.5$, $127.9,127.7,127.3,126.9,126.2,122.2,121.6,75.0,75.0,74.7,74.6,52.0,32.5,32.2,31.2,29.7,19.6$, 19.2, 14.2, 14.0. HRMS (ESI-TOF): $m / z:[M+N a]^{+}$Calcd for $\mathrm{C}_{84} \mathrm{H}_{90} \mathrm{O}_{8} \mathrm{Br}_{2} \mathrm{Na}^{+}:$1407.4895; Found 1407.4952

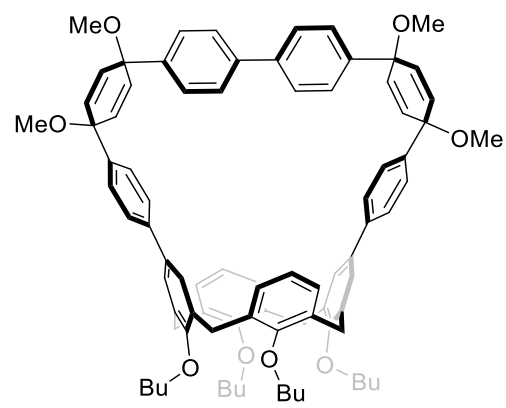

Compound (5). Inside the glove box, $\mathrm{Ni}(\operatorname{cod})_{2}(88.53 \mathrm{mg}, 0.32 \mathrm{mmol}, 2.5$ equiv), 2,2'-bipyridyl (50.27 $\mathrm{mg}, 0.32 \mathrm{mmol}, 2.5$ equiv), and anhydrous THF $(21.0 \mathrm{~mL})$ were sequentially added to a pressure tube equipped with a stir bar. After 5 min of stirring, a DMF solution of compound 4 (178.63 mg, $0.13 \mathrm{mmol}$, 1.0 equiv, $26.5 \mathrm{~mL}$ ) was added dropwise to above mixture during $2 \mathrm{~h}$. The tube was sealed with cap, transferred out of the glove box and stirred at $80^{\circ} \mathrm{C}$ for $16 \mathrm{~h}$ in an oil bath. The reaction mixture was cooled down to room temperature and evaporated under reduced pressure. Brine was added and the mixture was extracted with dichloromethane. The organic layer was dried over anhydrous sodium sulfate and evaporated under reduced pressure. The crude product was dissolved in dichloromethane, loaded on alumina by slow evaporation and purified by column chromatography (basic alumina grade III, $15 \%$ ethyl acetate in hexane) to get compound $\mathbf{5}(0.116 \mathrm{~g}, 74 \%)$ as a colorless solid. ${ }^{1} \mathbf{H}$ NMR (600 $\mathrm{MHz}$, chloroform-d, $300 \mathrm{~K}): \delta 7.51\left(4 \mathrm{H}, \mathrm{d},{ }^{3} \mathrm{~J}=8.4 \mathrm{~Hz}\right), 7.42(8 \mathrm{H}, \mathrm{m}), 7.28\left(4 \mathrm{H}, \mathrm{d},{ }^{3} J=8.6 \mathrm{~Hz}\right), 7.22(4 \mathrm{H}$, s), $7.03\left(4 \mathrm{H}, \mathrm{d}^{3}{ }^{3} \mathrm{~J}=7.6 \mathrm{~Hz}\right), 6.65\left(2 \mathrm{H}, \mathrm{t},{ }^{3} J=7.6 \mathrm{~Hz}\right), 6.29\left(4 \mathrm{H}, \mathrm{d},{ }^{3} J=10.2 \mathrm{~Hz}\right), 6.03\left(4 \mathrm{H}, \mathrm{d}^{3}{ }^{3} J=10.2 \mathrm{~Hz}\right)$, $4.57\left(4 \mathrm{H}, \mathrm{d},{ }^{2} J=12.0 \mathrm{~Hz}\right), 3.98\left(4 \mathrm{H}, \mathrm{t},{ }^{3} J=7.9 \mathrm{~Hz}\right), 3.91\left(4 \mathrm{H}, \mathrm{t},{ }^{3} J=7.8 \mathrm{~Hz}\right), 3.47(6 \mathrm{H}, \mathrm{s}), 3.44(6 \mathrm{H}, \mathrm{s}), 3.32$ $\left(4 \mathrm{H}, \mathrm{d},{ }^{2} J=12.1 \mathrm{~Hz}\right), 2.18\left(4 \mathrm{H}\right.$, quint, $\left.{ }^{3} J=5.2 \mathrm{~Hz}\right), 2.03\left(4 \mathrm{H}\right.$, quint, $\left.{ }^{3} J=7.8 \mathrm{~Hz}\right), 1.52\left(4 \mathrm{H}\right.$, sextet, ${ }^{3} J=7.6$ $\mathrm{Hz}), 1.47\left(4 \mathrm{H}\right.$, sextet, $\left.{ }^{3} \mathrm{~J}=7.6 \mathrm{~Hz}\right), 1.09\left(6 \mathrm{H}, \mathrm{t},{ }^{3} \mathrm{~J}=7.4 \mathrm{~Hz}\right), 1.05\left(6 \mathrm{H}, \mathrm{t},{ }^{3} \mathrm{~J}=7.4 \mathrm{~Hz}\right) .{ }^{13} \mathrm{C}$ NMR $(151 \mathrm{MHz}$, chloroform- $d, 300 \mathrm{~K}): \delta 155.8,155.7,142.3,141.6,141.5,139.3,135.9,135.8,134.7,133.9,132.8$, $128.2,127.7,127.6,126.8,126.2,126.0,123.3,75.7,75.5,75.0,74.4,52.0,51.9,32.5,32.3,30.5,19.3$, 19.3, 14.3, 14.2. HRMS (ESI-TOF): $\mathrm{m} / \mathrm{z}:[\mathrm{M}+\mathrm{H}]^{+}$Calcd for $\mathrm{C}_{84} \mathrm{H}_{90} \mathrm{O}_{8} \mathrm{H}^{+}: 1227.6708$; Found 1227.6723. $m / z:[\mathrm{M}+\mathrm{Na}]^{+}$Calcd for $\mathrm{C}_{84} \mathrm{H}_{90} \mathrm{O}_{8} \mathrm{Na}^{+}:$1249.6528; Found 1249.6543. 


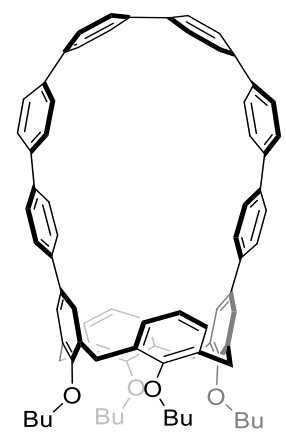

Compound (1). Under a nitrogen atmosphere, concentrated hydrochloric acid ( $207 \mu \mathrm{L}, 3.05 \mathrm{mmol}, 16$ equiv) was added to a sunspension of $\mathrm{SnCl}_{2} \cdot 2 \mathrm{H}_{2} \mathrm{O}(354.71 \mathrm{mg}, 1.52 \mathrm{mmol}, 8$ equiv) in $9 \mathrm{~mL} \mathrm{THF}$ and stirred for $15 \mathrm{~min}$. Subsequently, the resulting mixture was added dropwise to a solution containing compound 5 (234 mg, 0.19 mmol, 1 equiv) in $14 \mathrm{~mL}$ of THF, which turned immedately from colorless to yellow and was stirred at RT overnight. To the resulting mixture, a $10 \%$ aqueous $\mathrm{NaOH}$ solution was added, and extracted with dichloromethane. The combined organic layers were washed with brine, dried over sodium sulfate, filtered and concentrated under reduce pressure. The crude residue was passed through a short column (silica, dichloromethane/ethyl acetate, 1:0.01). The pure compound $\mathbf{5}$ was obtained after purification by GPC (Figure $\mathbf{S 1}, 180 \mathrm{mg}, 86 \%$ ). ${ }^{1} \mathrm{H}$ NMR (600 MHz, chloroform- $d, 300$ K): $\delta 7.59\left(4 \mathrm{H}, d^{3}{ }^{3} J=9.0 \mathrm{~Hz}\right), 7.54\left(4 \mathrm{H}, \mathrm{d}^{3}{ }^{3} \mathrm{~J}=9.0 \mathrm{~Hz}\right), 7.51\left(4 \mathrm{H}, \mathrm{d}^{3}{ }^{3} \mathrm{~J}=8.6 \mathrm{~Hz}\right), 7.39\left(4 \mathrm{H}, \mathrm{d}^{3}{ }^{3} \mathrm{~J}=8.6 \mathrm{~Hz}\right)$, $7.36\left(4 \mathrm{H}, \mathrm{d},{ }^{3} J=8.5 \mathrm{~Hz}\right), 7.29\left(4 \mathrm{H}, \mathrm{d},{ }^{3} J=8.5 \mathrm{~Hz}\right), 7.15(4 \mathrm{H}, \mathrm{s}), 7.09\left(4 \mathrm{H}, \mathrm{d},{ }^{3} J=7.7 \mathrm{~Hz}\right), 6.74\left(2 \mathrm{H}, \mathrm{t}^{3}{ }^{3} J=\right.$ $7.6 \mathrm{~Hz}), 4.55\left(4 \mathrm{H}, \mathrm{d},{ }^{2} J=12.2 \mathrm{~Hz}\right), 4.06\left(4 \mathrm{H}, \mathrm{t},{ }^{3} J=8.2 \mathrm{~Hz}\right), 3.83\left(4 \mathrm{H}, \mathrm{t},{ }^{3} J=7.6 \mathrm{~Hz}\right), 3.30\left(4 \mathrm{H}, \mathrm{d}^{2}{ }^{2} \mathrm{~J}=12.2\right.$ $\mathrm{Hz}), 2.22\left(4 \mathrm{H}\right.$, quint, $\left.{ }^{3} \mathrm{~J}=8.0 \mathrm{~Hz}\right), 1.94\left(4 \mathrm{H}\right.$, quint, $\left.{ }^{3} \mathrm{~J}=7.6 \mathrm{~Hz}\right), 1.47\left(8 \mathrm{H}\right.$, septet, $\left.{ }^{3} \mathrm{~J}=7.5 \mathrm{~Hz}\right), 1.09(6 \mathrm{H}, \mathrm{t}$, $\left.{ }^{3} \mathrm{~J}=7.4 \mathrm{~Hz}\right), 1.02\left(6 \mathrm{H}, \mathrm{t},{ }^{3} \mathrm{~J}=7.4 \mathrm{~Hz}\right) .{ }^{13} \mathrm{C}$ NMR $(151 \mathrm{MHz}$, chloroform-d , $300 \mathrm{~K}): \delta$ 156.6, 155.7, 138.7, 138.4, 138.3, 138.0, 137.9, 136.9, 135.7, 134.1, 133.6, 128.7, 127.9, 127.4, 127.4, 127.3, 127.1, 126.5, 126.4, 123.1, 76.2, 74.7, 32.4, 32.2, 31.0, 19.4, 19.3, 14.3, 14.1. HRMS (ESI-TOF): $\mathrm{m} / \mathrm{z}:[\mathrm{M}+\mathrm{Na}]^{+} \mathrm{Calcd}$ for $\mathrm{C}_{80} \mathrm{H}_{78} \mathrm{O}_{4} \mathrm{Na}^{+}$: 1125.5792; Found 1125.5733. UV-vis (dichloromethane, $\left.298 \mathrm{~K}\right) \lambda[\mathrm{nm}]\left(\varepsilon\right.$ in $\left.\mathrm{M}^{-1} \mathrm{~cm}^{-1}\right)$ : 327 (78500), 377 (18200). 
Additional Schemes 


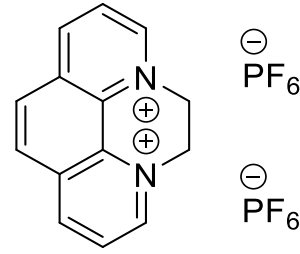

$\left[\mathrm{PQ}^{2+}\right]\left[\mathrm{PF}_{6}\right]_{2}$

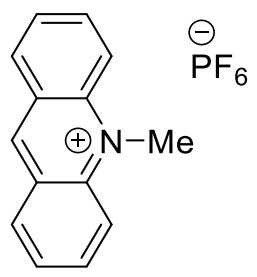

$\left[\mathrm{MA}^{+}\right]\left[\mathrm{PF}_{6}^{-}\right]$

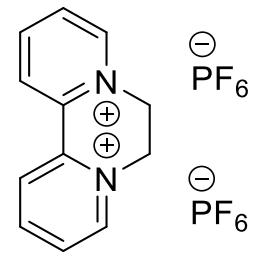

$\left[\mathrm{DQ}^{2+}\right]\left[\mathrm{PF}_{6}{ }^{-}\right]_{2}$

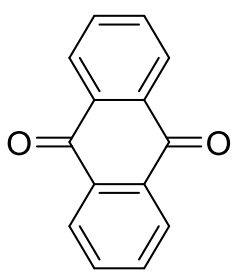

$A Q$

Scheme S2. Structures of the guests molecules.<smiles>[R]Oc1ccc(C)cc1</smiles>

$+$

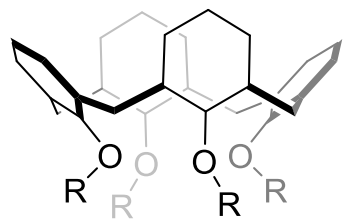

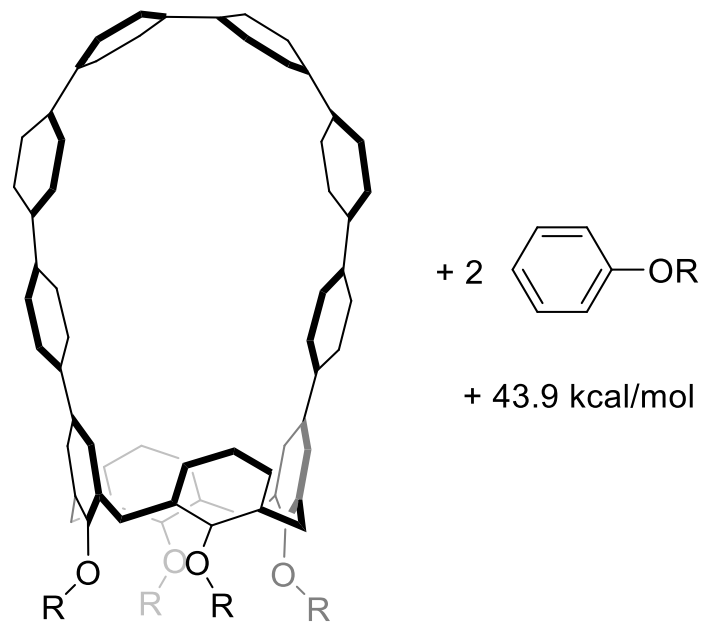

$\mathrm{R}$

Scheme S3. Homodesmotic strain calculation for 1. $\Delta H$ is given at the B3LYP-GD3BJ/6-31G(d,p) level of theory. 
1. 14.31

2. 19.38 or 19.28

3. 32.22

4. 74.75

5. 156.64

6. 135.74

7. 128.71

8. 123.13

9. 14.09

10. 19.38 or 19.28

11. 32.41

12. 76.21

13. 31.02

14. 155.74

15. 134.13

16. 126.37

17. 138.74

18. 138.36 or 138.33

19. 127.10

20. 126.47

21. 133.57

22. 138.02

23. 127.36

24. 127.30

25. 138.36 or 138.33

26. $136 . .89$

27. 127.93

28. 127.43

29. 137.90

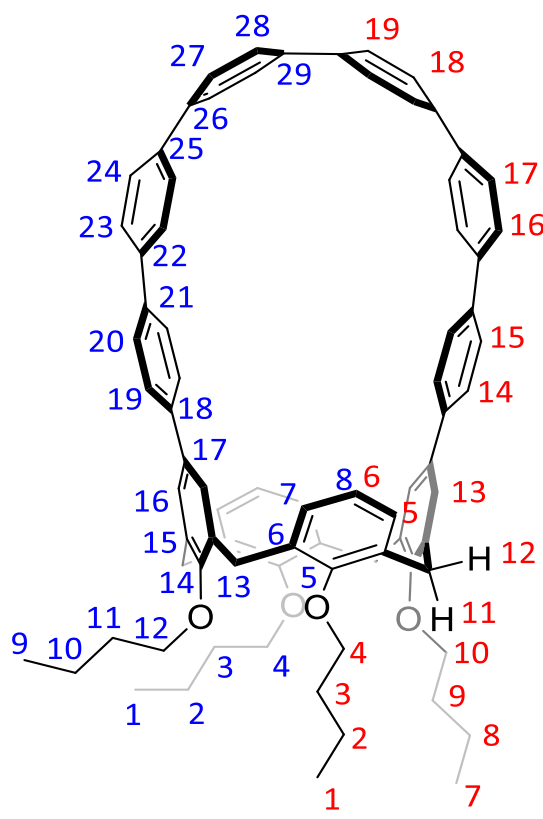

1. 1.09

2. 1.47

3. 2.22

4. 4.06

5. 7.09

6. $\quad 6.74$

7. 1.02

8. 1.47

9. 1.94

10. 3.83

11. 4.55

12. 3.30

13. 7.15

14. 7.29

15. 7.36

16. 7.39

17. 7.51

18. 7.54

19. 7.59

Scheme S4. ${ }^{1} \mathrm{H}$ and ${ }^{13} \mathrm{C}$ NMR chemical shifts of 1 . The assignment was based on data obtained from COSY, NOESY (Figure S2), HSQC and HMBC (Figure S3, Figure S4) experiments. 
Additional Figures 


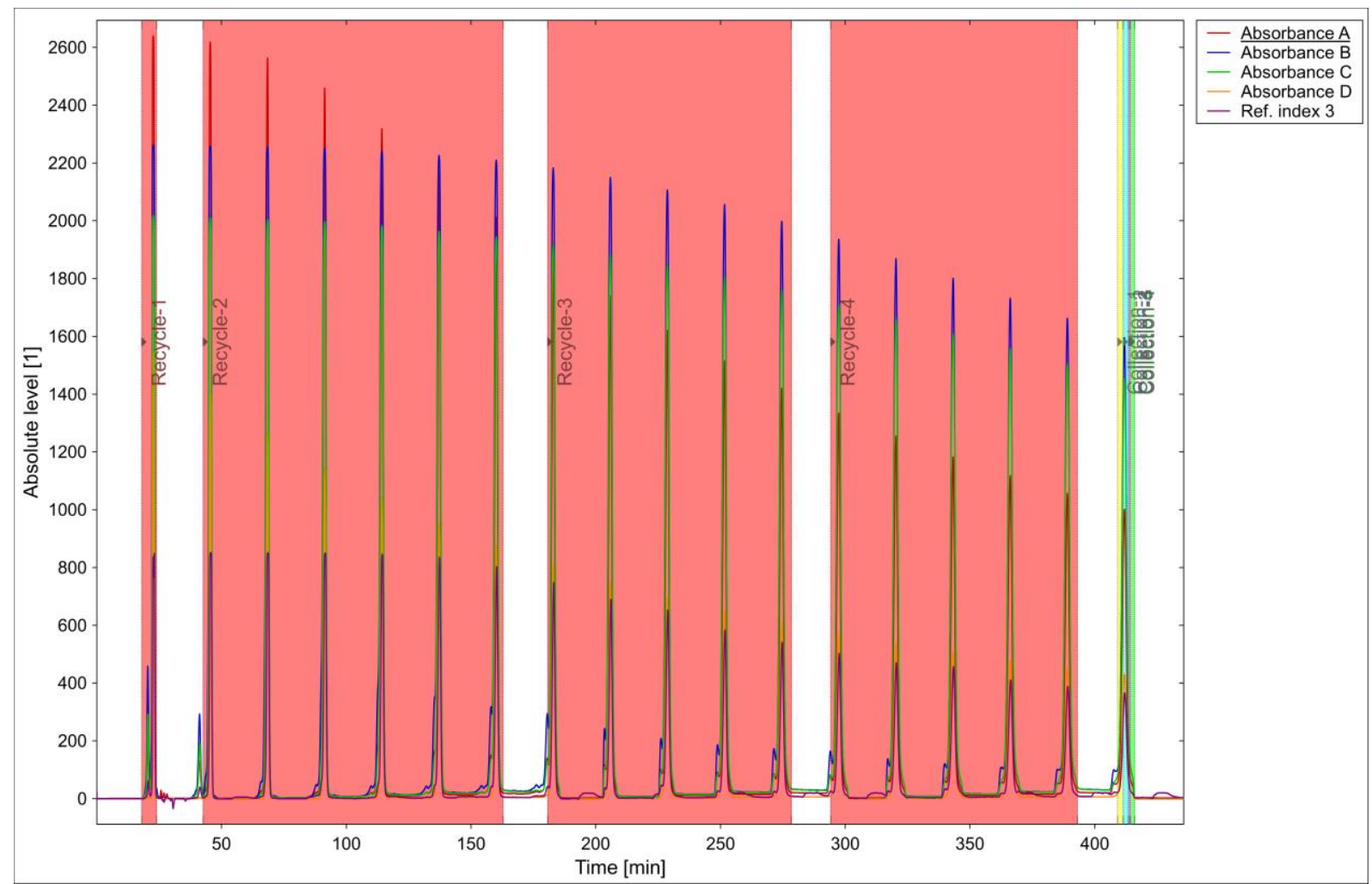

Figure S1. GPC chromatogram for compound 1 purification. Wavelenghts: $A=254 \mathrm{~nm}, B=310 \mathrm{~nm}, C$ $=350 \mathrm{~nm}, \mathrm{D}=415 \mathrm{~nm}$. 


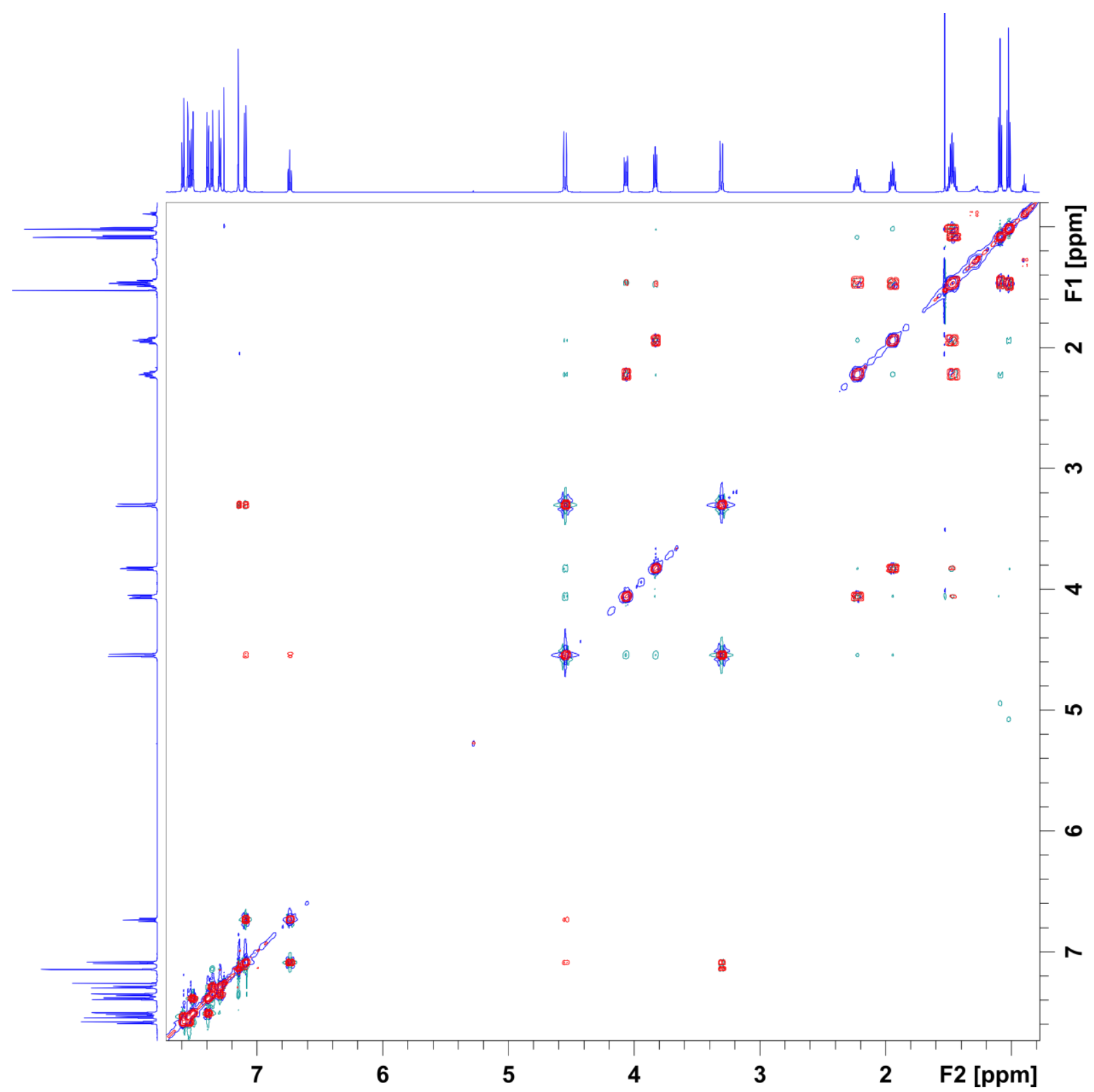

Figure S2. Overlaid NOESY (blue/green) and COSY (red) spectra of 1 (600 MHz, chloroform-d, $300 \mathrm{~K}$ ). 


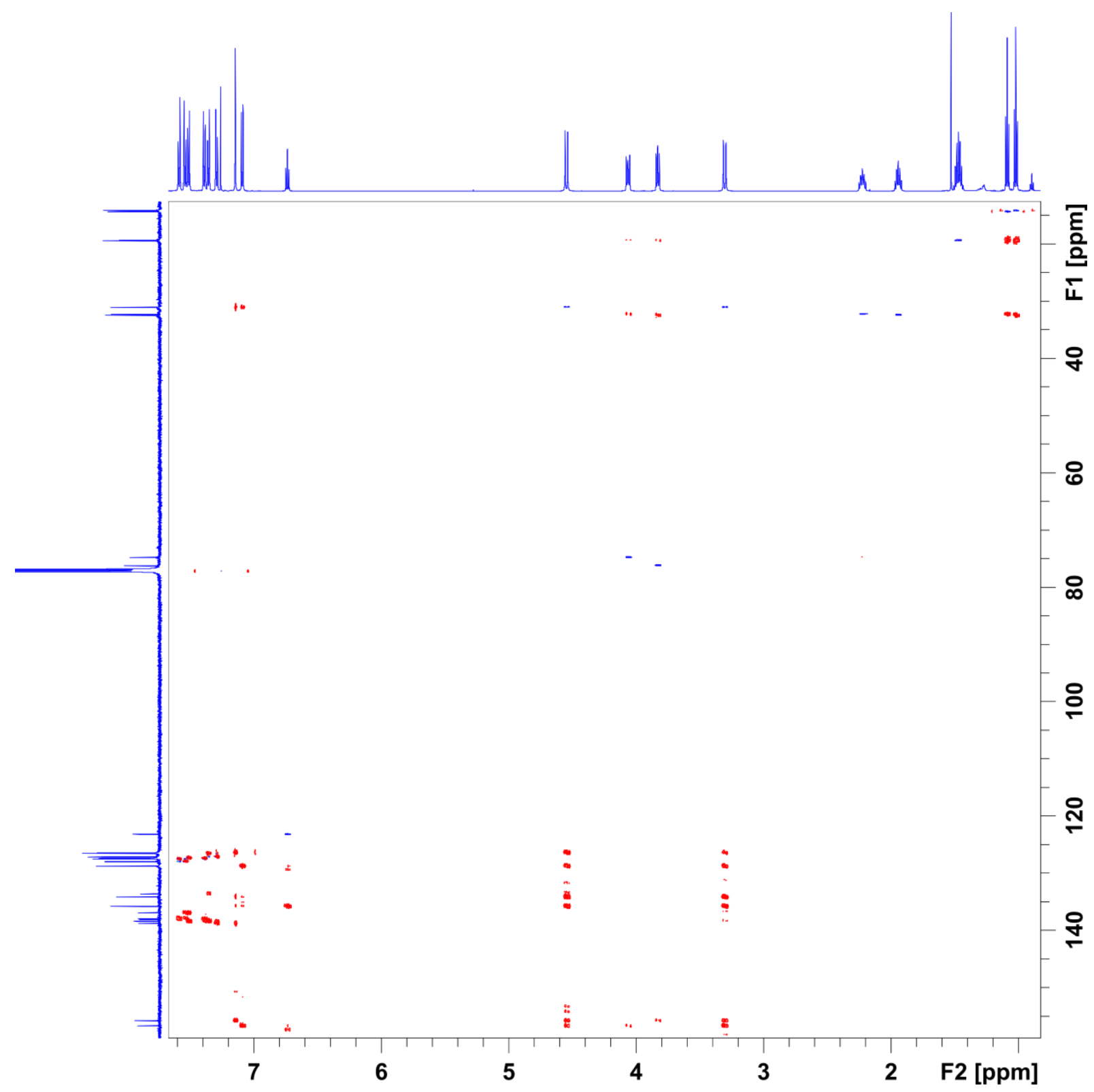

Figure S3. Overlaid HSQC (blue) and HMBC (red) spectra of 1 (600 MHz, chloroform-d, $300 \mathrm{~K}$ ). 


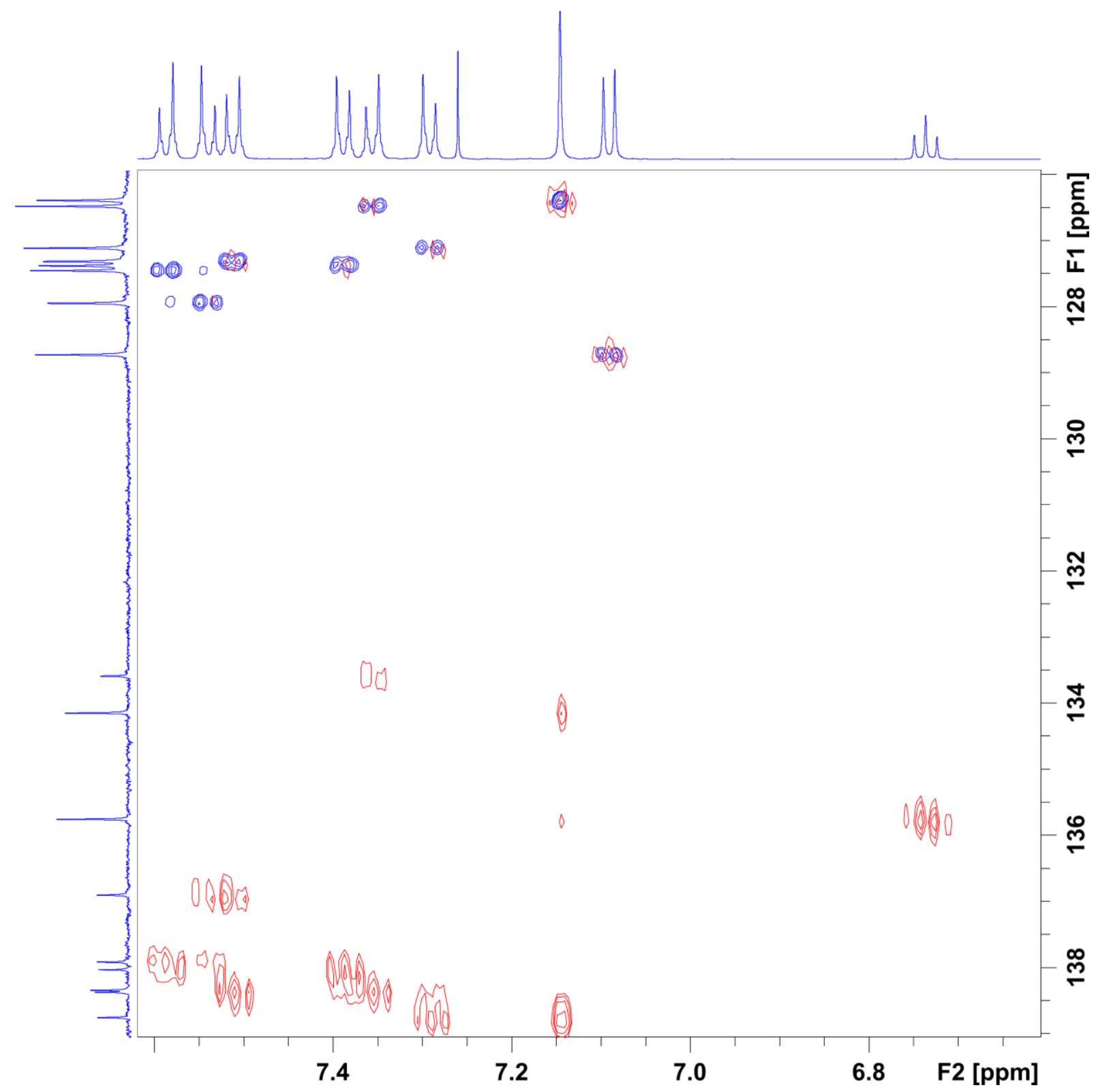

Figure S4. Partial HSQC (blue) and HMBC (red) spectra of 1 (600 MHz, chloroform-d, $300 \mathrm{~K}$ ). 


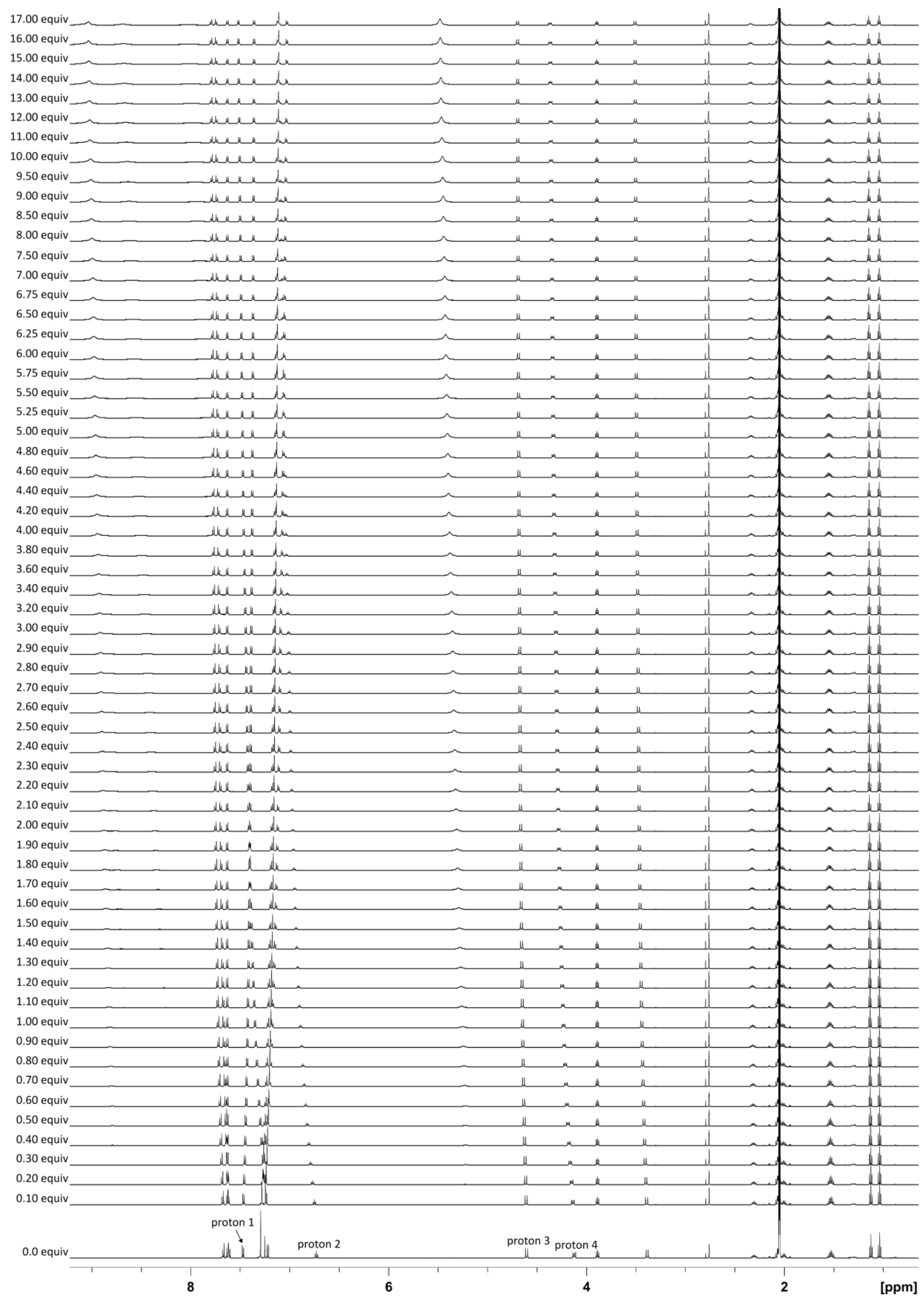

Figure S5. ${ }^{1} \mathrm{H}$ NMR titration spectra $\left(600 \mathrm{MHz}\right.$, acetone- $d_{6}, 300 \mathrm{~K}$ ) obtained upon addition of 0-17 equiv. of a $10.87 \mathrm{mM}$ solution of $\left[\mathrm{DQ}^{2+}\right]\left[\mathrm{PF}_{6}{ }^{-}\right]_{2}$, prepared with a $1.81 \mathrm{mM}$ solution of 1 , to a $1.81 \mathrm{mM}$ solution of 1. 


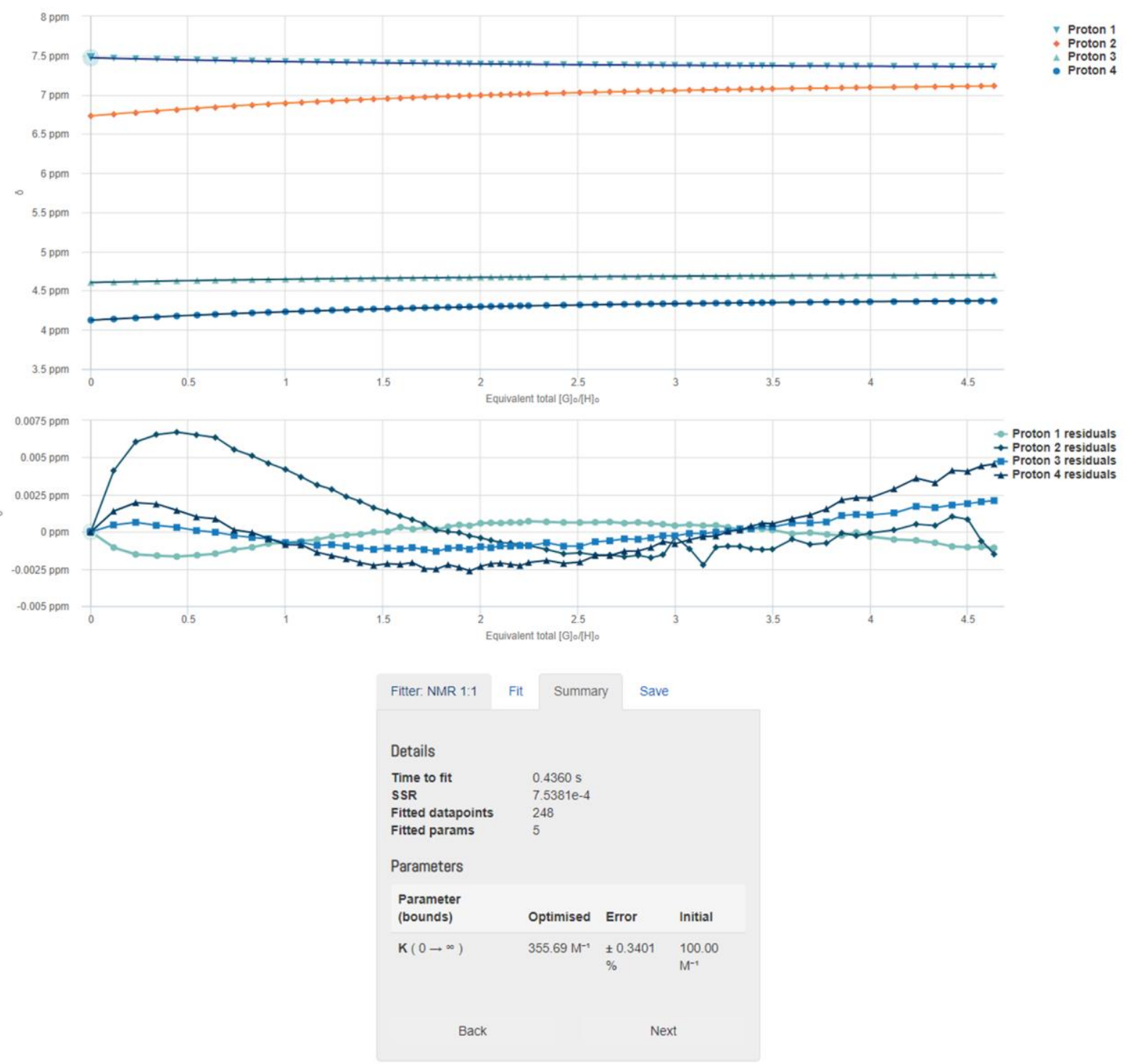

Figure S6. Nonlinear least-squares analysis of the ${ }^{1} \mathrm{H}$ NMR binding data (Figure S5) corresponding to the formation of $\left[\mathbf{1} \supset \mathrm{DQ}^{2+}\right]\left[\mathrm{PF}_{6}{ }^{-}\right]_{2}$ complex. The data were fitted to a 1:1 (host:guest) binding model to give $K_{11}=3.56(1) \cdot 10^{2} \mathrm{M}^{-1}$. The residual distribution is shown below the binding isotherm. All solid lines were obtained from non-linear curve-fitting with the Nelder-Mead method to a 1:1 binding model using the http://supramolecular.org/web applet. 


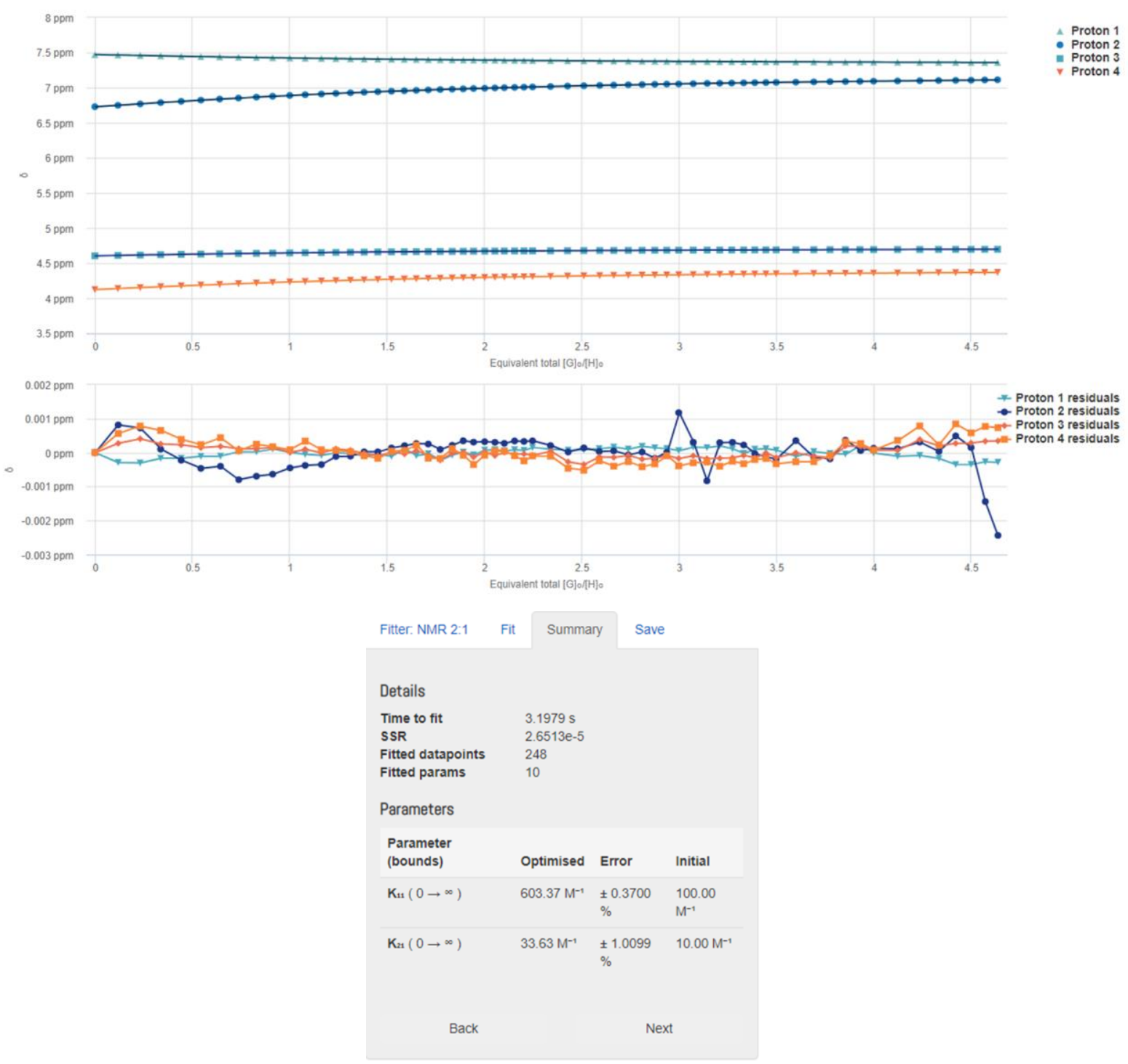

Figure S7. Nonlinear least-square analysis of the ${ }^{1} \mathrm{H}$ NMR binding data (Figure S5) corresponding to the formation of $\left[1 \supset \mathrm{DQ}^{2+}\right]\left[\mathrm{PF}_{6}^{-}\right]_{2}$ and $\left[\mathbf{1}_{2} \supset \mathrm{DQ}^{2+}\right]\left[\mathrm{PF}_{6}{ }^{-}\right]_{2}$ complexes. The data were fitted to a $2: 1$ (host:guest) binding model to give $K_{11}=6.03(2) \cdot 10^{2} \mathrm{M}^{-1}$ and $K_{21}=3.36(3) \cdot 10^{1} \mathrm{M}^{-1}$. The residual distribution is shown below the binding isotherm. All solid lines were obtained from non-linear curvefitting with the Nelder-Mead method to a 2:1 binding model using the http://supramolecular.org/web applet. 


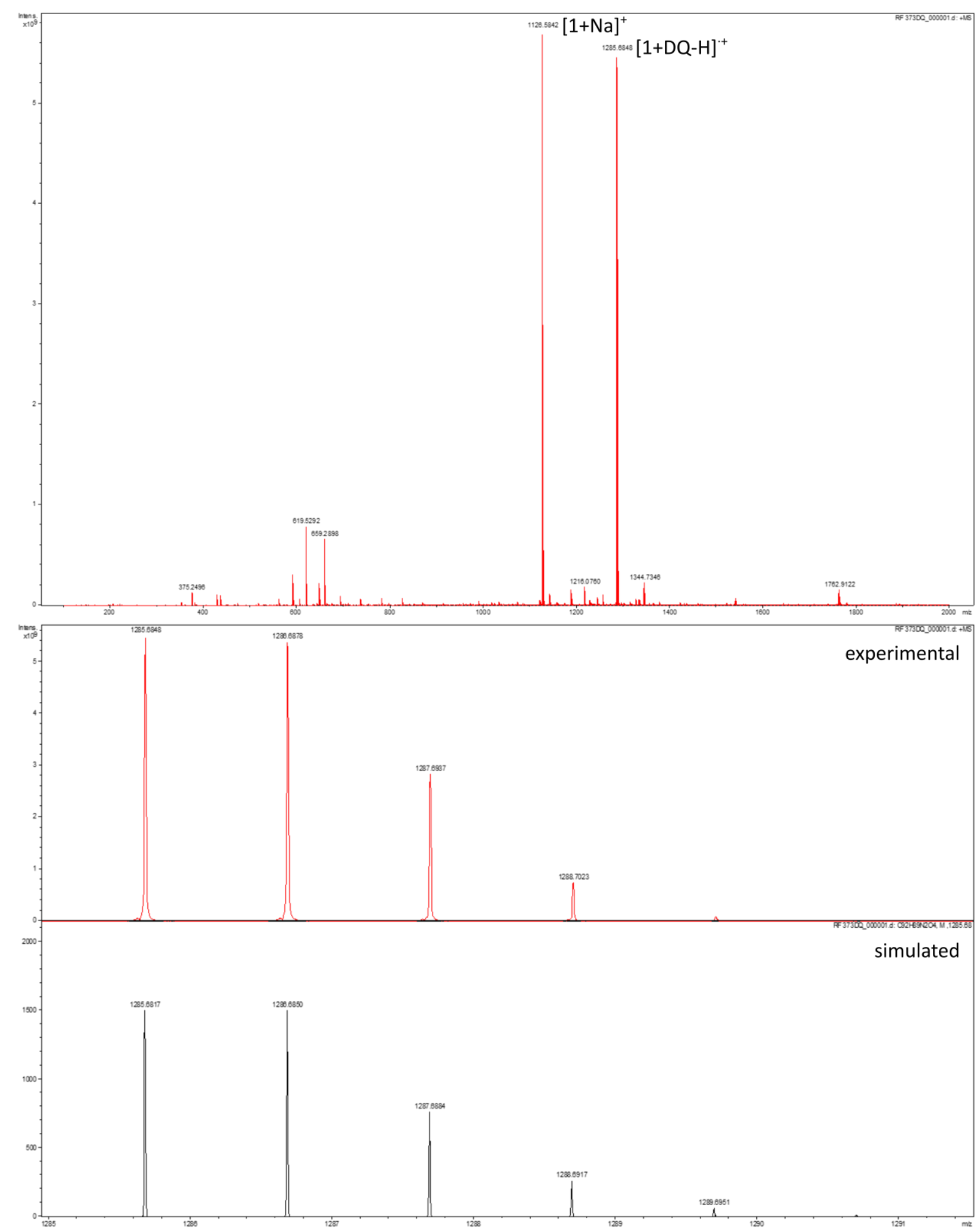

Figure S8. ESI-TOF mass spectrum of an equimolar mixture of $\mathbf{1}$ and $\left[\mathrm{DQ}^{2+}\right]\left[\mathrm{PF}_{6}{ }^{-}\right]_{2}$ in acetone. [1+DQ$\mathrm{H}]^{++}=\mathrm{C}_{92} \mathrm{H}_{89} \mathrm{~N}_{2} \mathrm{O}_{4}$. 


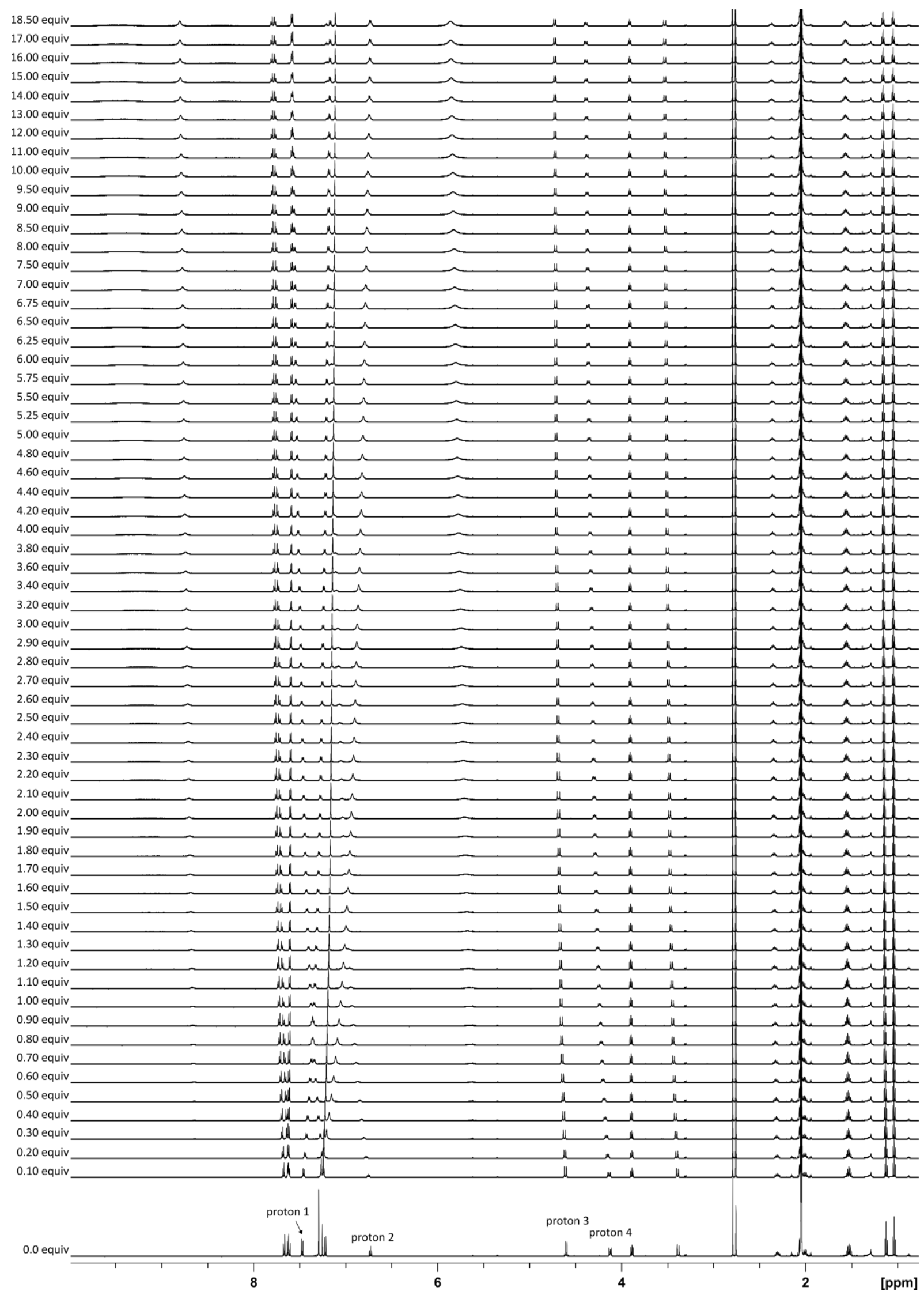

Figure 59. ${ }^{1} \mathrm{H}$ NMR titration spectra $\left(600 \mathrm{MHz}\right.$, acetone- $\left.d_{6}, 300 \mathrm{~K}\right)$ obtained upon addition of 0-18.5 equiv of a $5.437 \mathrm{mM}$ solution of $\left[\mathrm{PQ}^{2+}\right]\left[\mathrm{PF}_{6}{ }^{-}\right]_{2}$, prepared with a $0.906 \mathrm{mM}$ solution of 1 , to a $0.906 \mathrm{mM}$ solution of 1. 

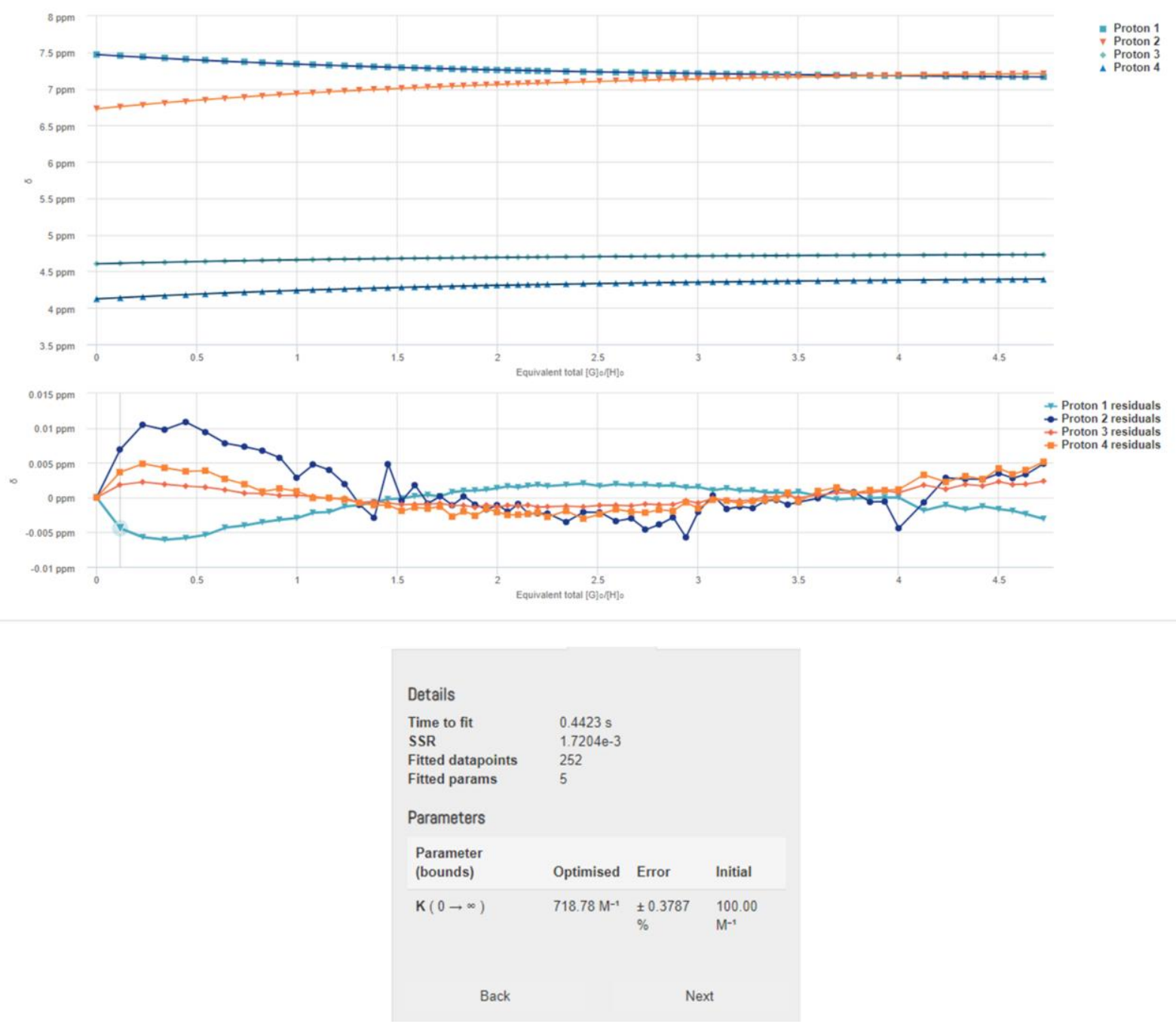

Figure S10. Nonlinear least-square analysis of the ${ }^{1} \mathrm{H}$ NMR binding data (Figure S9) corresponding to the formation of $\left[\mathbf{1} \supset \mathrm{PQ}^{2+}\right]\left[\mathrm{PF}_{6}{ }^{-}\right]_{2}$ complex. The data were fitted to a 1:1 (host:guest) binding model to give $K_{11}=7.19(3) \cdot 10^{2} \mathrm{M}^{-1}$. The residual distribution is shown below the binding isotherm. All solid lines were obtained from non-linear curve-fitting with the Nelder-Mead method to a 1:1 binding model using the http://supramolecular.org/web applet. 

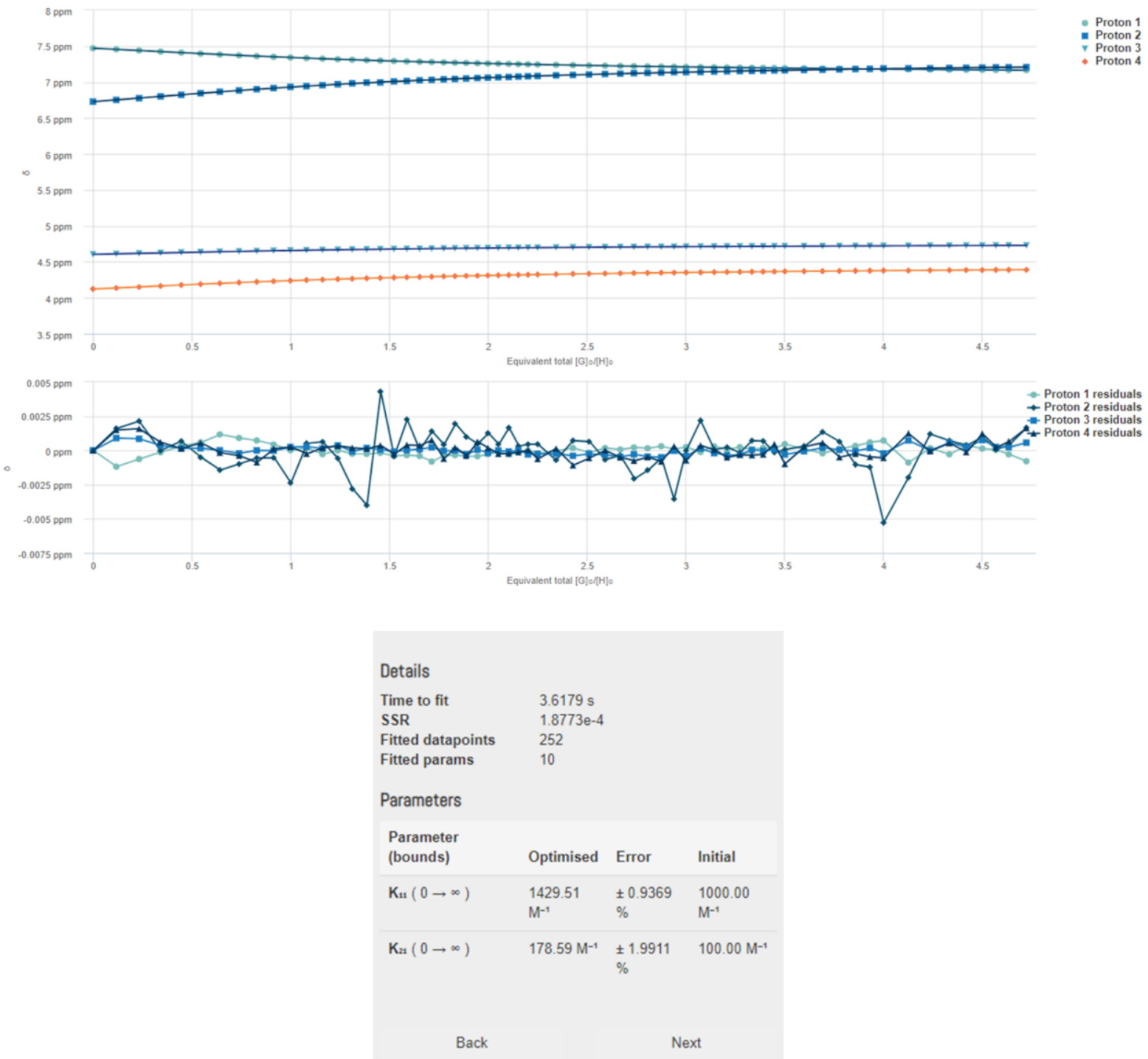

Figure S11. Nonlinear least-square analysis of the ${ }^{1} \mathrm{H}$ NMR binding data (Figure S9) corresponding to the formation of $\left[\mathbf{1} \supset \mathrm{PQ}^{2+}\right]\left[\mathrm{PF}_{6}{ }^{-}\right]_{2}$ and $\left[\mathbf{1}_{2} \supset \mathrm{PQ}^{2+}\right]\left[\mathrm{PF}_{6}^{-}\right]_{2}$ complexes. The data were fitted to a $2: 1$ (host:guest) binding model to give $K_{11}=1.43(1) \cdot 10^{3} \mathrm{M}^{-1}$ and $K_{21}=1.78(4) \cdot 10^{2} \mathrm{M}^{-1}$. The residual distribution is shown below the binding isotherm. All solid lines were obtained from non-linear curvefitting with the Nelder-Mead method to a 2:1 binding model using the http://supramolecular.org/web applet. 


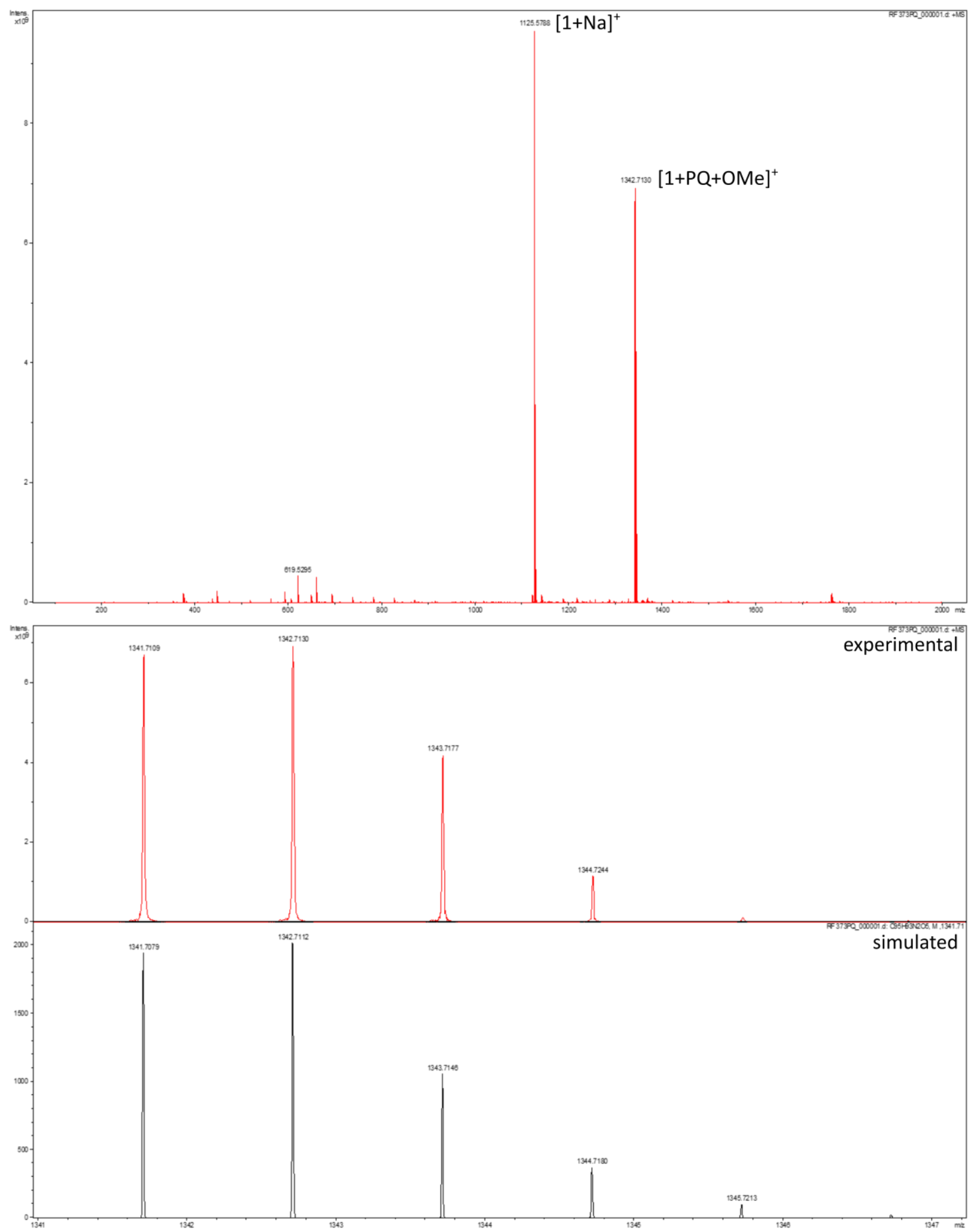

Figure S12. ESI-TOF mass spectrum of an equimolar mixture of 1 and $\left[\mathrm{PQ}^{2+}\right]\left[\mathrm{PF}_{6}{ }^{-}\right]_{2}$ in acetone. $[1+\mathrm{PQ}+\mathrm{OMe}]^{+}=\mathrm{C}_{95} \mathrm{H}_{93} \mathrm{~N}_{2} \mathrm{O}_{5}$. 


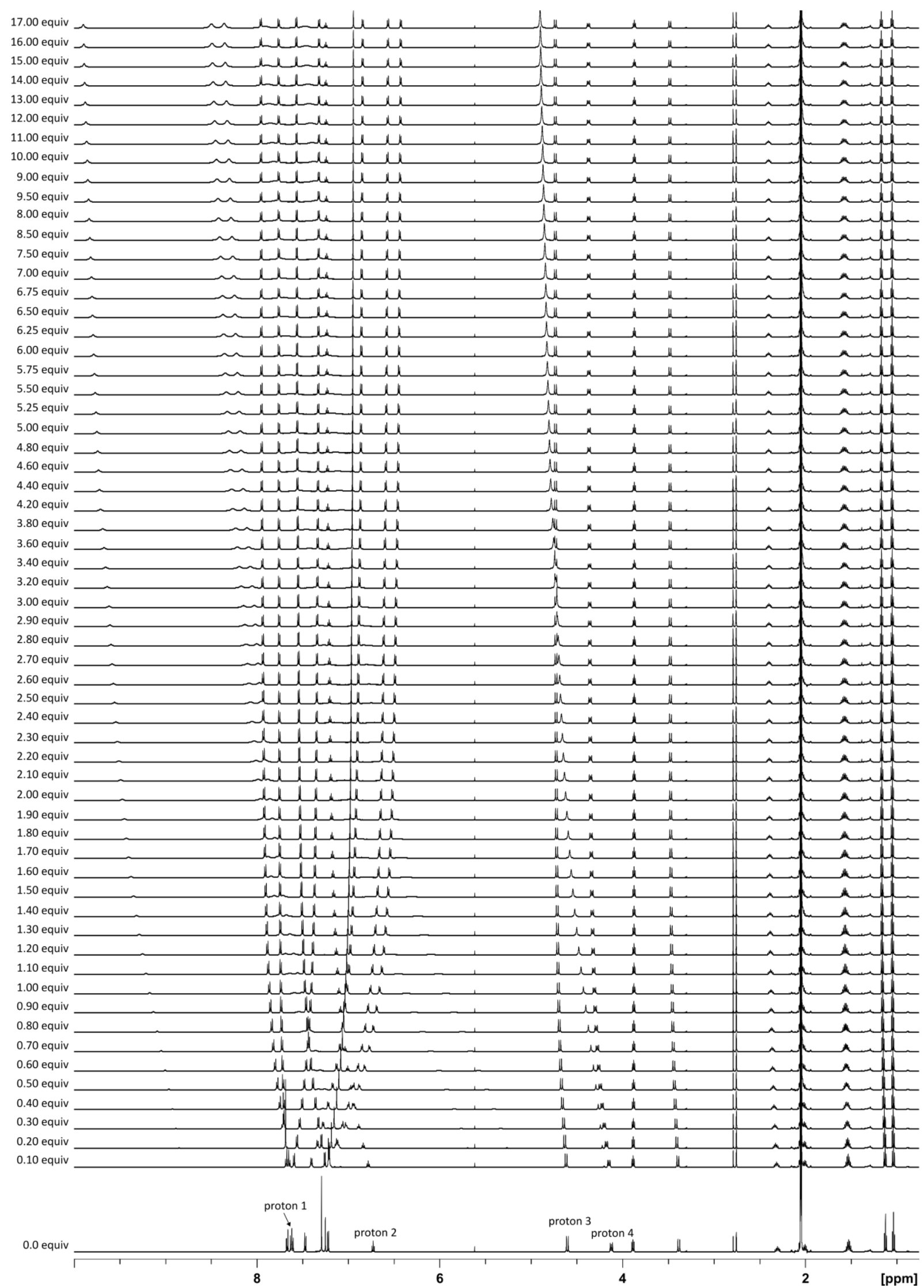

Figure S13. ${ }^{1} \mathrm{H}$ NMR titration spectra $\left(600 \mathrm{MHz}\right.$, acetone- $\left.d_{6}, 300 \mathrm{~K}\right)$ obtained upon addition of $0-17$ equiv. of a $10.87 \mathrm{mM}$ solution of $\left[\mathrm{MA}^{+}\right]\left[\mathrm{PF}_{6}{ }^{-}\right]$, prepared with a $1.81 \mathrm{mM}$ solution of 1 , to a $1.81 \mathrm{mM}$ solution of 1 . 

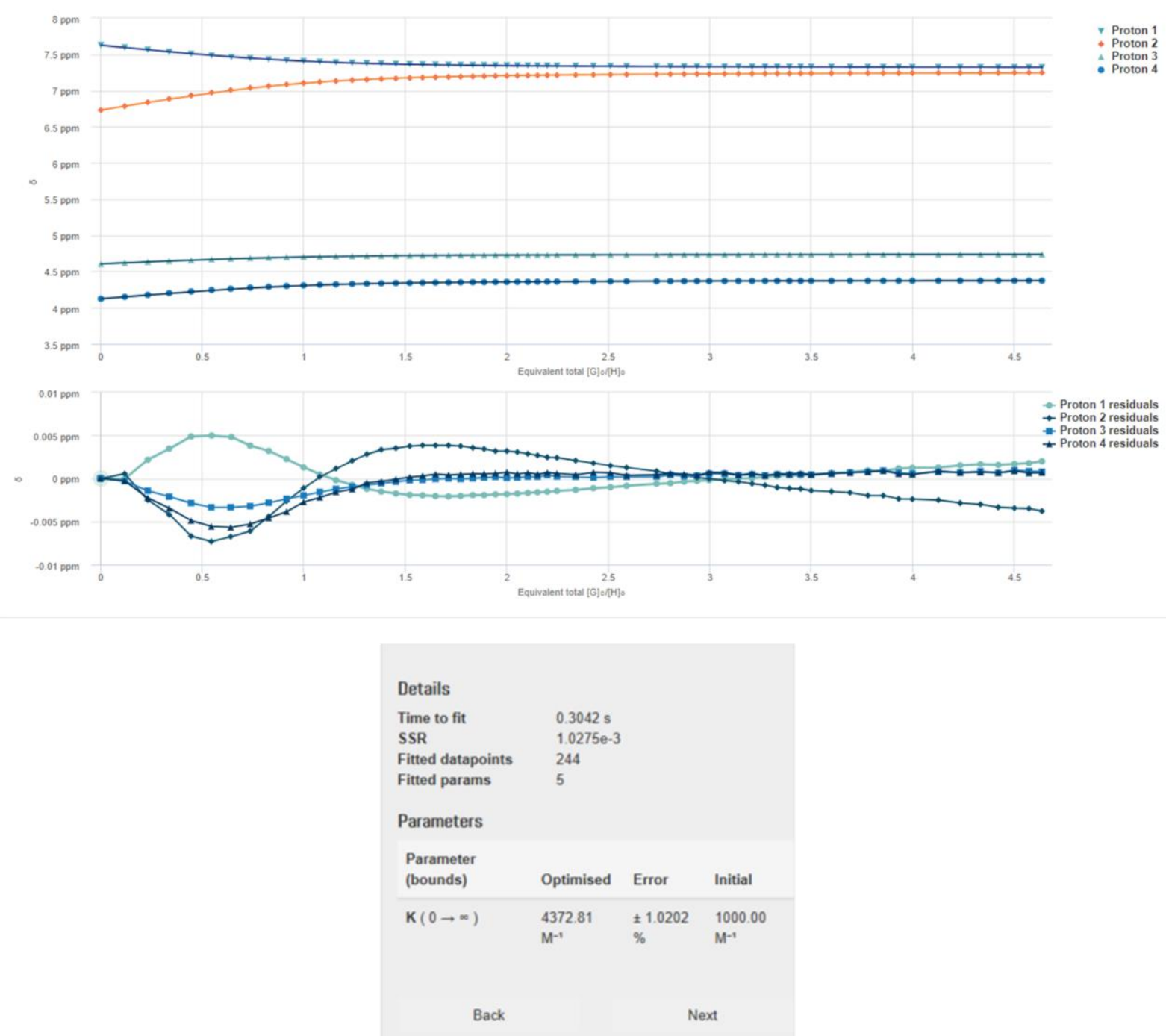

Figure S14. Nonlinear least-square analysis of the ${ }^{1} \mathrm{H}$ NMR binding data (Figure S13) corresponding to the formation of $\left[1 \supset \mathrm{MA}^{+}\right]\left[\mathrm{PF}_{6}{ }^{-}\right]$complex. The data were fitted to a 1:1 (host:guest) binding model to give $K_{11}=4.37(4) \cdot 10^{3} \mathrm{M}^{-1}$. The residual distribution is shown below the binding isotherm. All solid lines were obtained from non-linear curve-fitting with the Nelder-Mead method to a 1:1 binding model using the http://supramolecular.org/ web applet. 

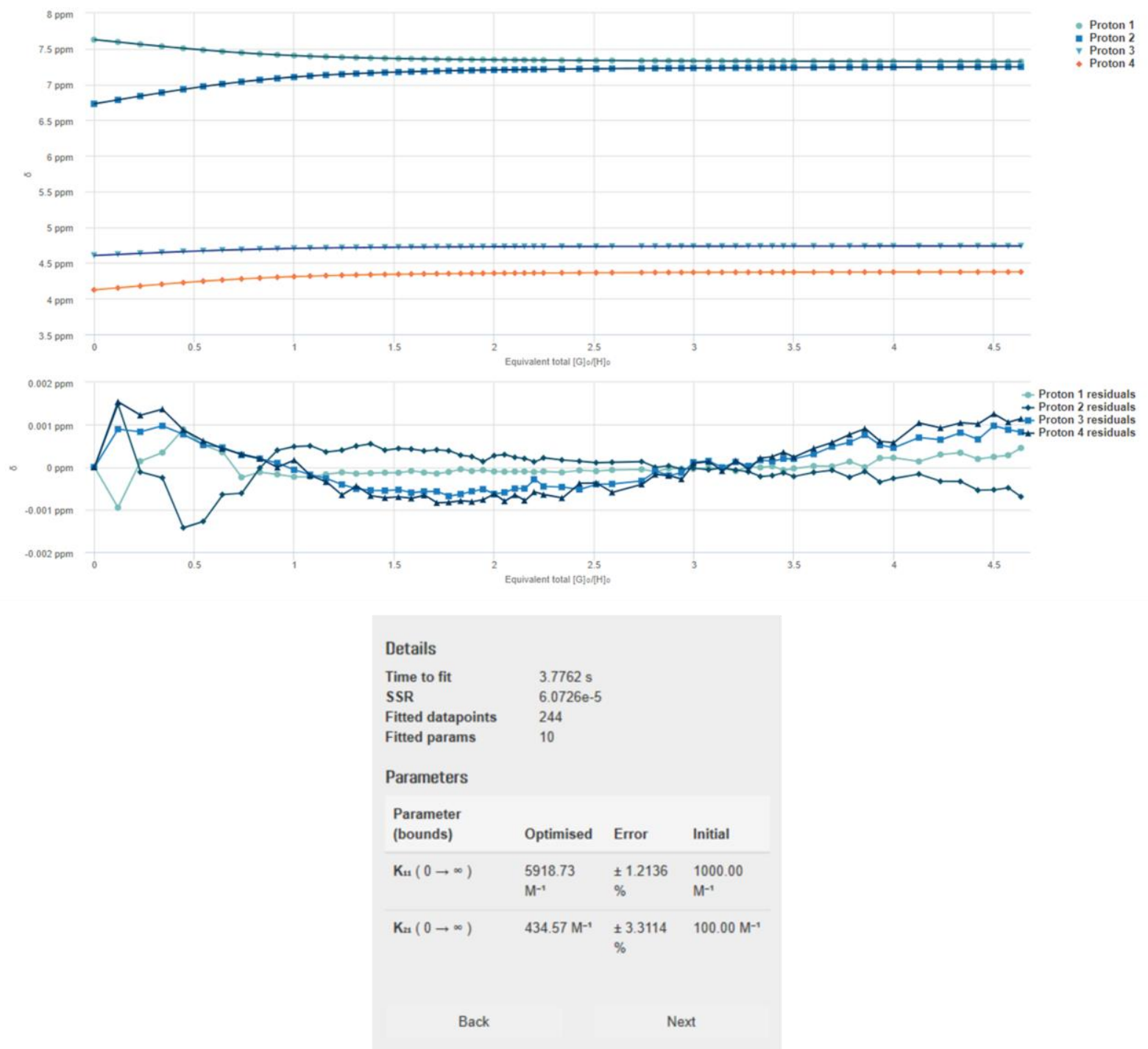

Figure S15. Nonlinear least-square analysis of the ${ }^{1} \mathrm{H}$ NMR binding data (Figure S13) corresponding to the formation of $\left[1 \supset \mathrm{MA}^{+}\right]\left[\mathrm{PF}_{6}{ }^{-}\right]$and $\left[\mathbf{1}_{2} \supset \mathrm{MA}^{+}\right]\left[\mathrm{PF}_{6}{ }^{-}\right]$complexes. The data were fitted to a $2: 1$ (host:guest) binding model to give $K_{11}=5.92(7) \cdot 10^{3} \mathrm{M}^{-1}$ and $K_{21}=4.3(1) \cdot 10^{2} \mathrm{M}^{-1}$. The residual distribution is shown below the binding isotherm. All solid lines were obtained from non-linear curvefitting with the Nelder-Mead method to a 2:1 binding model using the http://supramolecular.org/ web applet. 


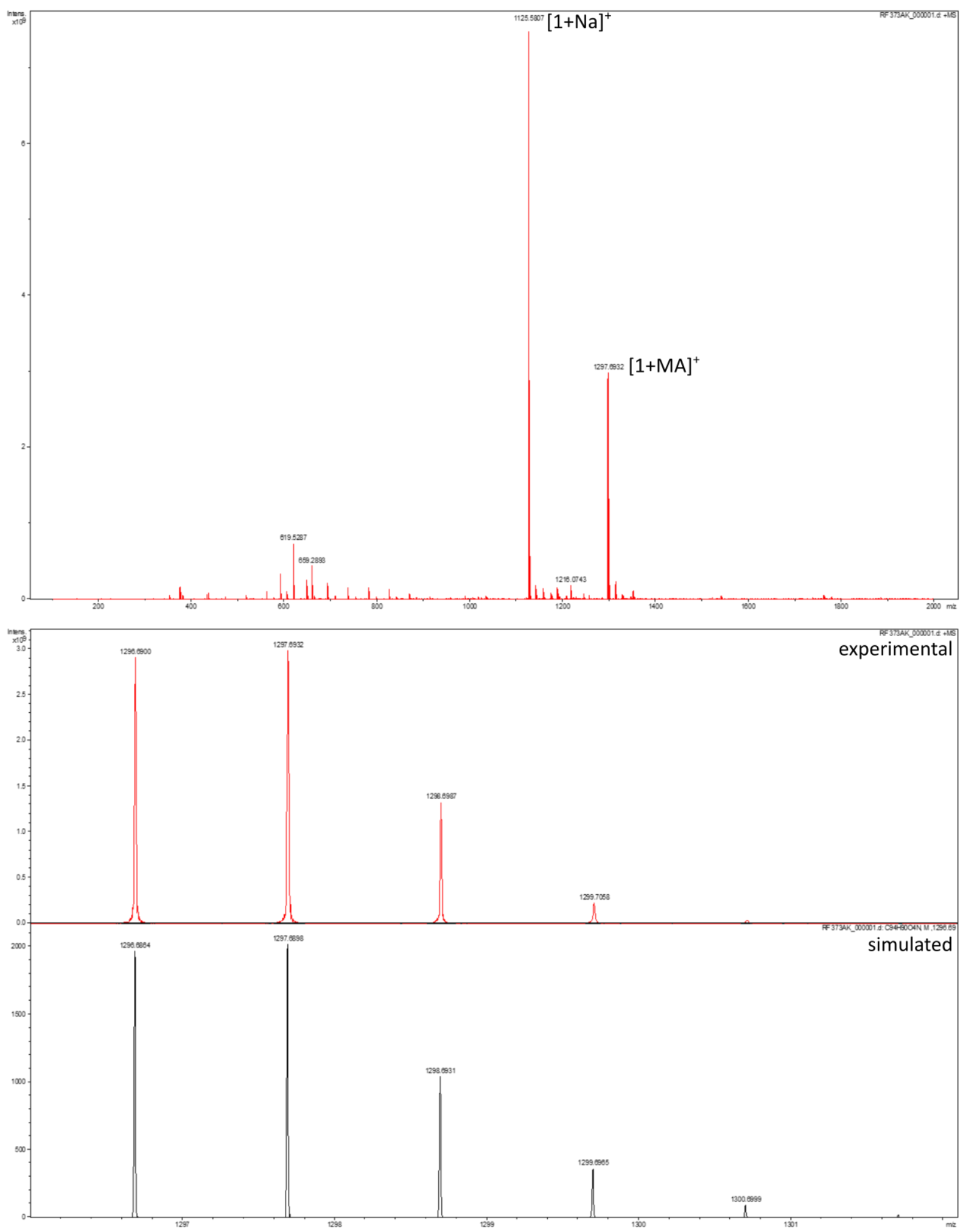

Figure S16. ESI-TOF mass spectrum of an equimolar mixture of 1 and $\left[\mathrm{MA}^{+}\right]\left[\mathrm{PF}_{6}\right]$ in acetone. $[1+\mathrm{MA}]^{+}=$ $\mathrm{C}_{94} \mathrm{H}_{90} \mathrm{NO}_{4}$. 


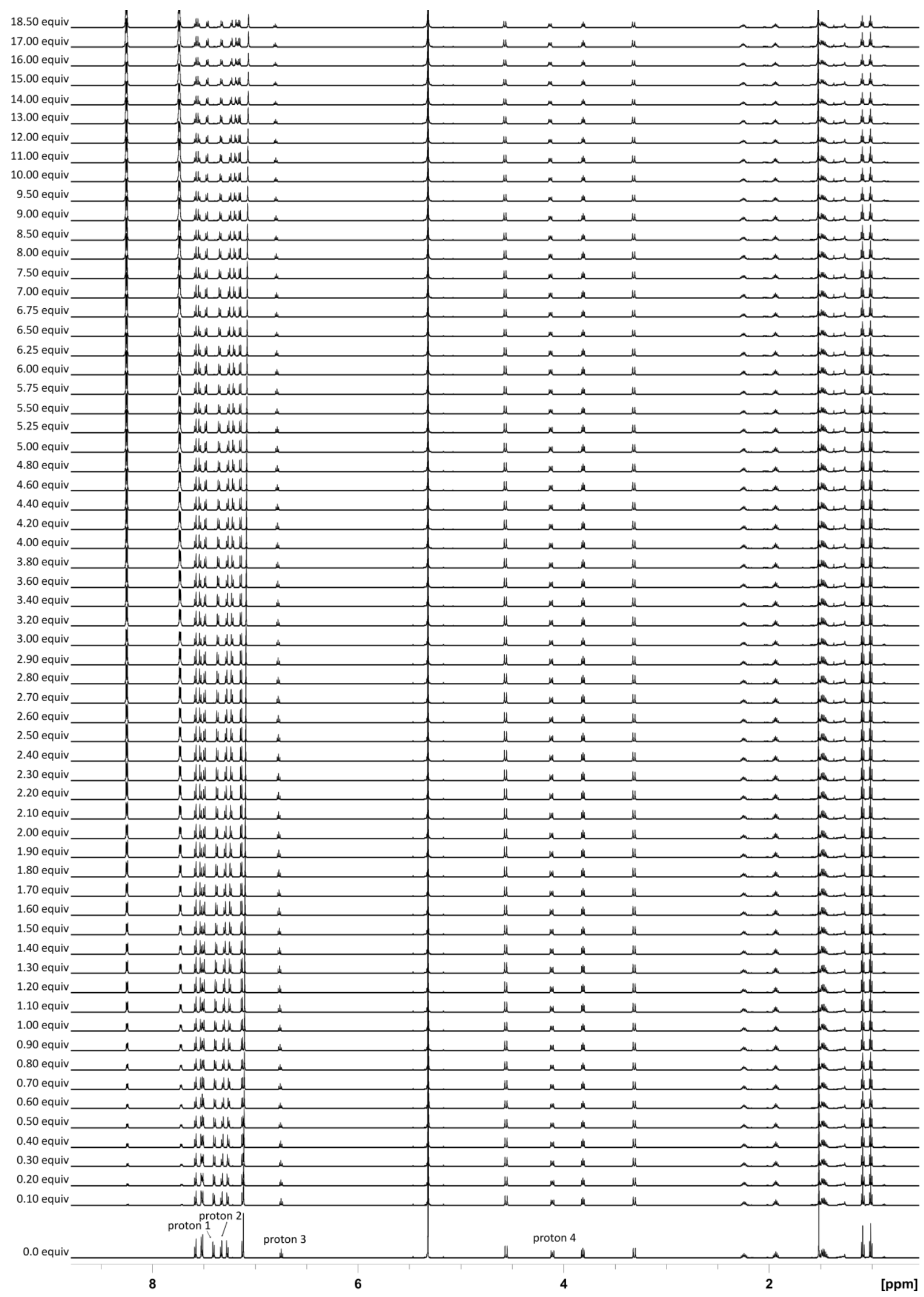

Figure S17. ${ }^{1} \mathrm{H}$ NMR titration spectra $\left(600 \mathrm{MHz}\right.$, dichoromethane- $d_{2}, 300 \mathrm{~K}$ ) obtained upon addition of 0-18.5 equiv. of a $10.87 \mathrm{mM}$ solution of $\mathrm{AQ}$, prepared with a $1.81 \mathrm{mM}$ solution of 1 , to a $1.81 \mathrm{mM}$ solution of 1. 


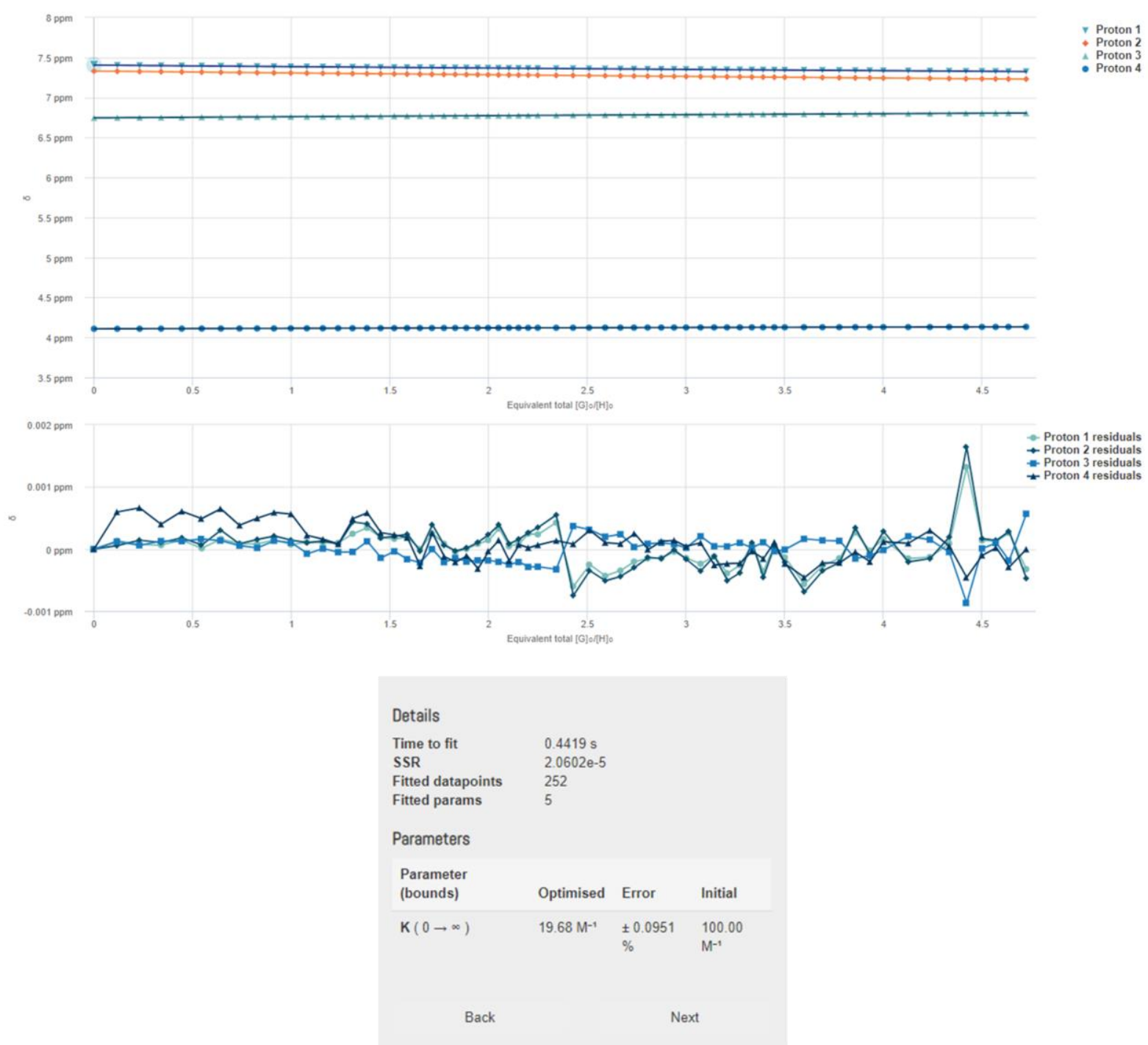

Figure S18. Nonlinear least-square analysis of the ${ }^{1} \mathrm{H}$ NMR binding data (Figure S17) corresponding to the formation of $1 \supset \mathrm{AQ}$ complex. The data were fitted to a 1:1 (host:guest) binding model to give $K_{11}=$ $1.968(2) \cdot 10^{1} \mathrm{M}^{-1}$. The residual distribution is shown below the binding isotherm. All solid lines were obtained from non-linear curve-fitting with the Nelder-Mead method to a 1:1 binding model using the http://supramolecular.org/ web applet. 


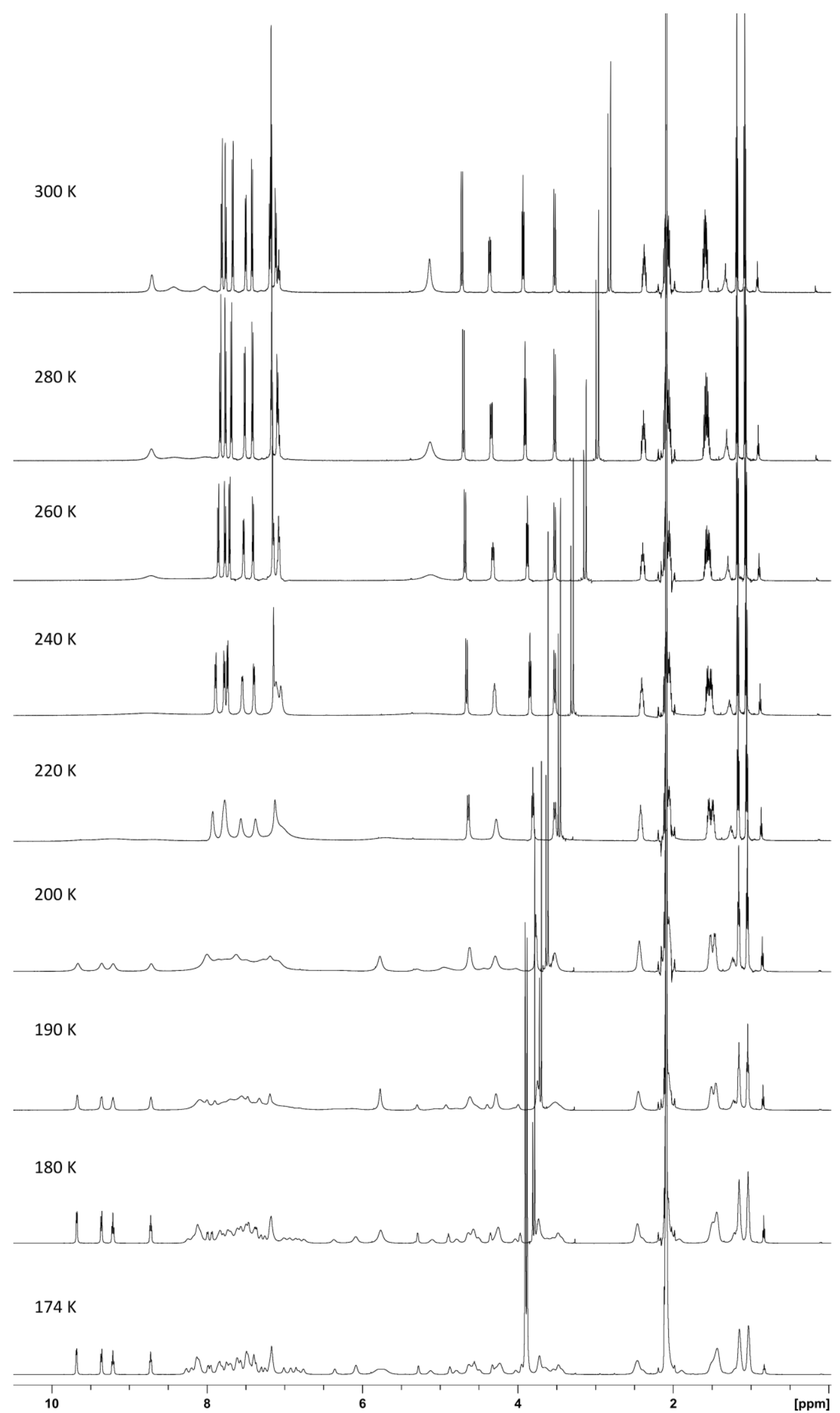

Figure S19. Variable temperature ${ }^{1} \mathrm{H}$ NMR spectra $\left(600 \mathrm{MHz}\right.$, acetone- $\left.d_{6}\right)$ of 1 with 1.5 equiv of $\left[\mathrm{DQ}^{2+}\right]\left[\mathrm{PF}_{6}^{-}\right]_{2}$. 

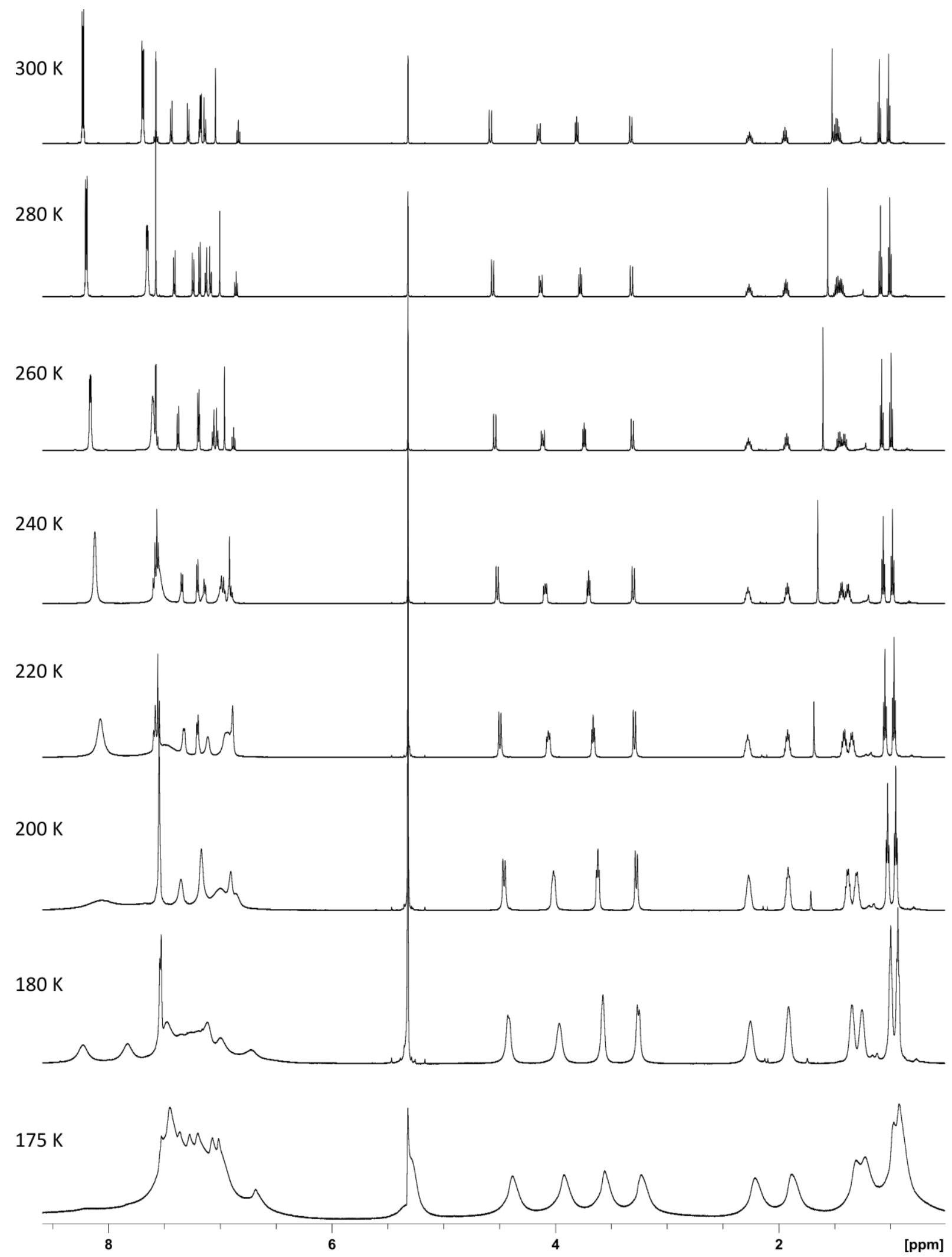

Figure S20. Variable temperature ${ }^{1} \mathrm{H}$ NMR spectra ( $600 \mathrm{MHz}$, dichloromethane- $d_{2}$ ) of 1 with 4.0 equiv of [AQ]. 


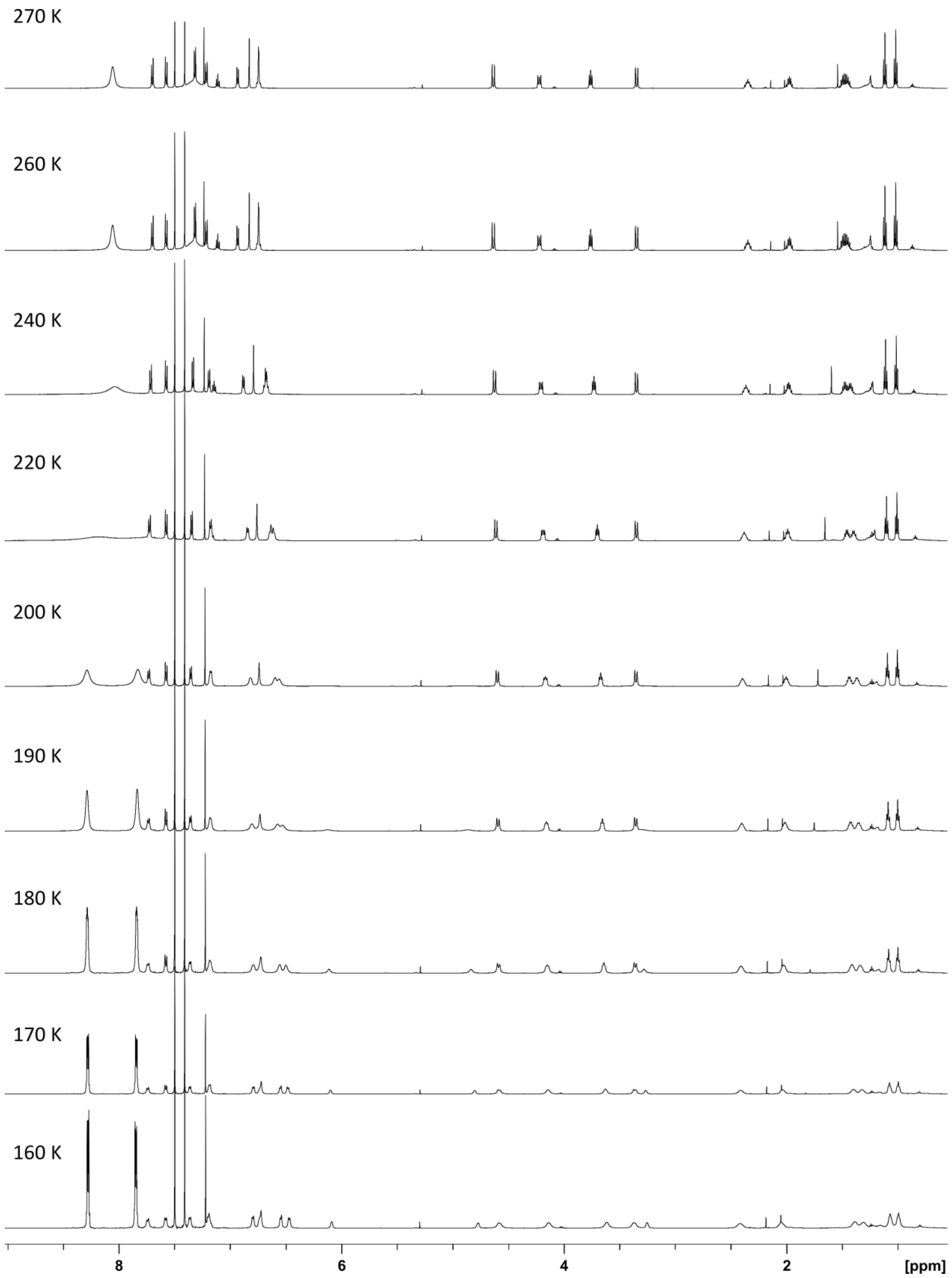

Figure S21. Variable temperature ${ }^{1} \mathrm{H}$ NMR spectra (600 MHz, DCFM-d) of 1 with 4.0 equiv of [AQ]. 


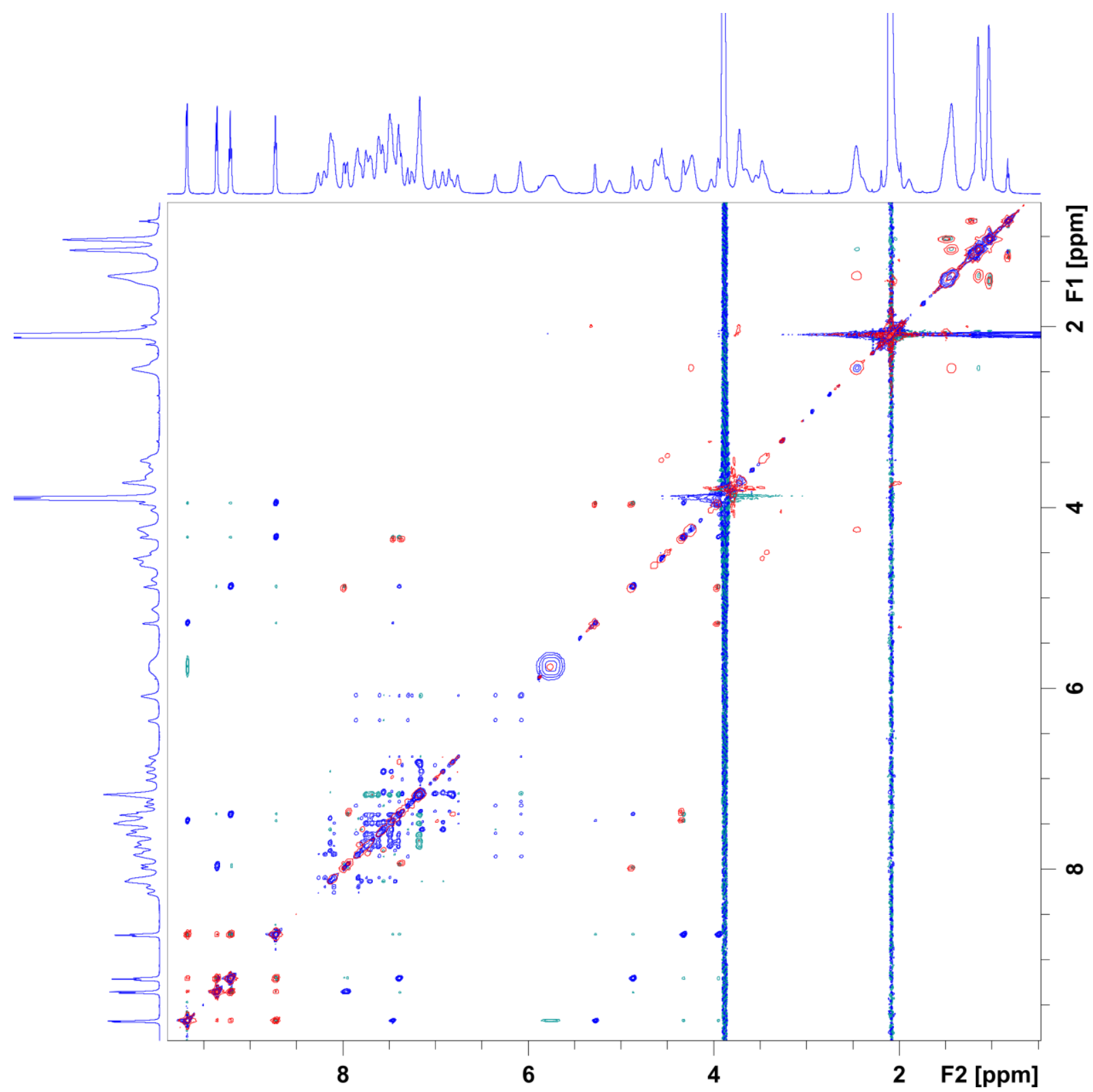

Figure S22. Overlaid ROESY (blue/green for positive/negative contours) and COSY (red) spectra of 1 with 1.5 equiv of $\left[\mathrm{DQ}^{2+}\right]\left[\mathrm{PF}_{6}^{-}\right]_{2}\left(600 \mathrm{MHz}\right.$, acetone- $\left.d_{6}, 174 \mathrm{~K}\right)$. 


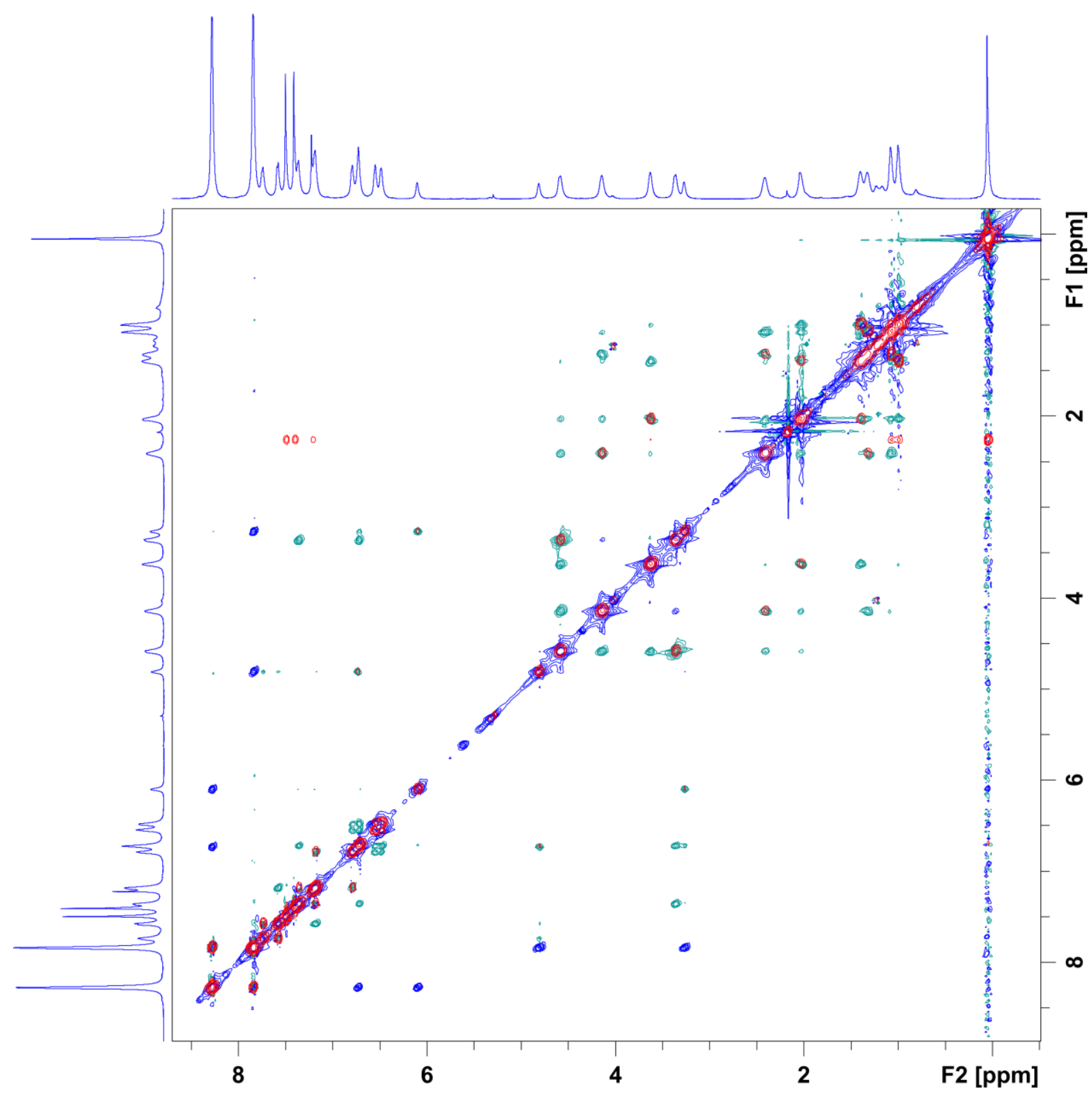

Figure S23. Overlaid ROESY (blue/green for positive/negative contours) and COSY (red) spectra of 1 with 4.0 equiv of $\mathrm{AQ}(600 \mathrm{MHz}, \mathrm{DCFM}-d, 170 \mathrm{~K})$. 


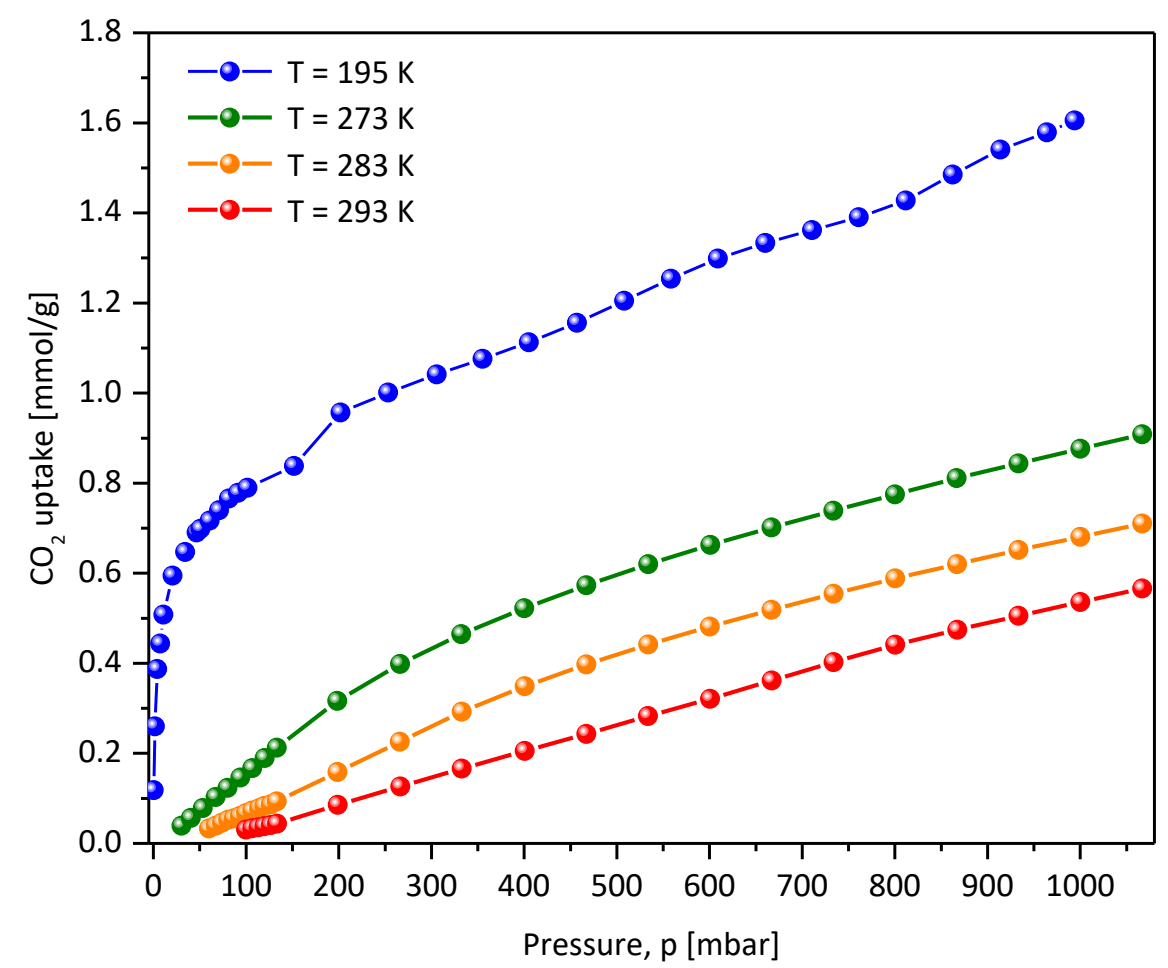

Figure S24. Experimental $\mathrm{CO}_{2}$ adsorption isotherms for 1 at 195, 273, 283 and $293 \mathrm{~K}$.

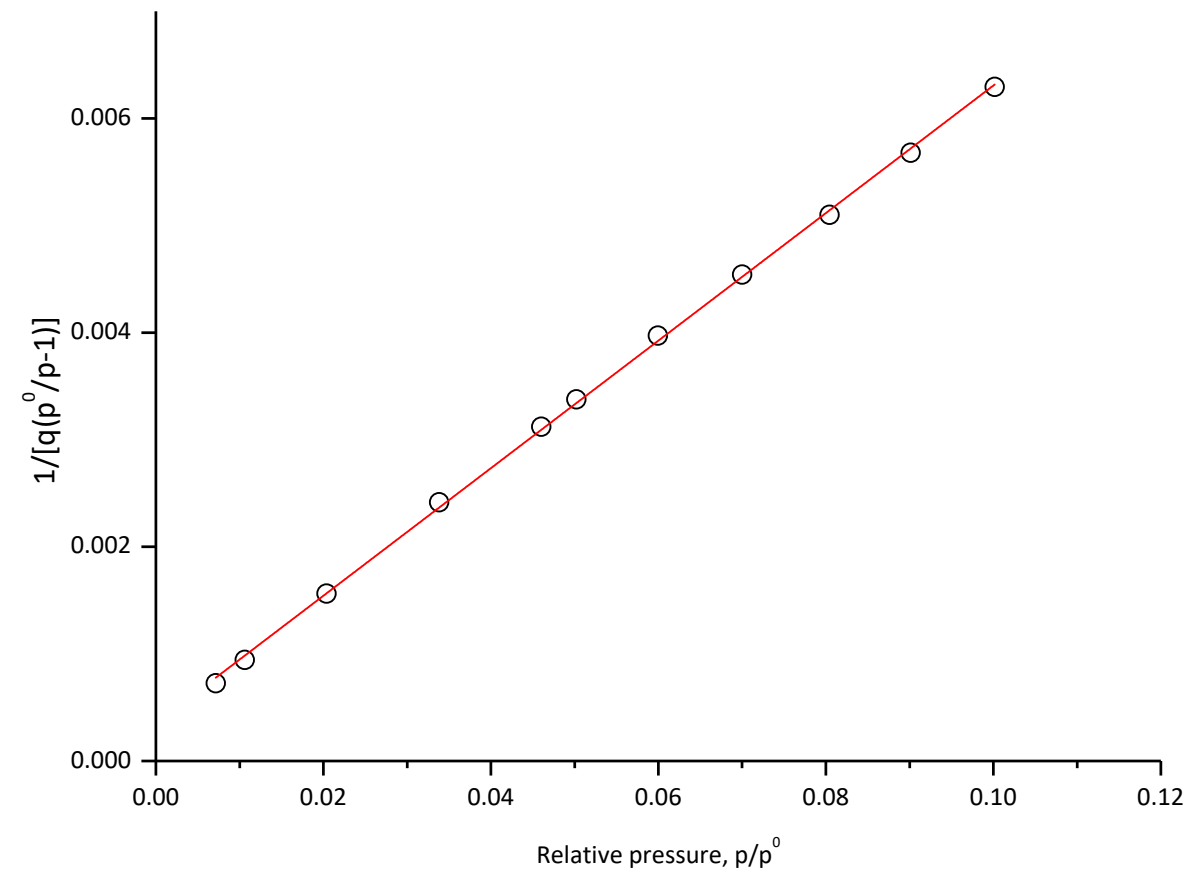

Figure S25. The BET plot derived from $\mathrm{CO}_{2}$ isotherm at $195 \mathrm{~K}$ for 1. 


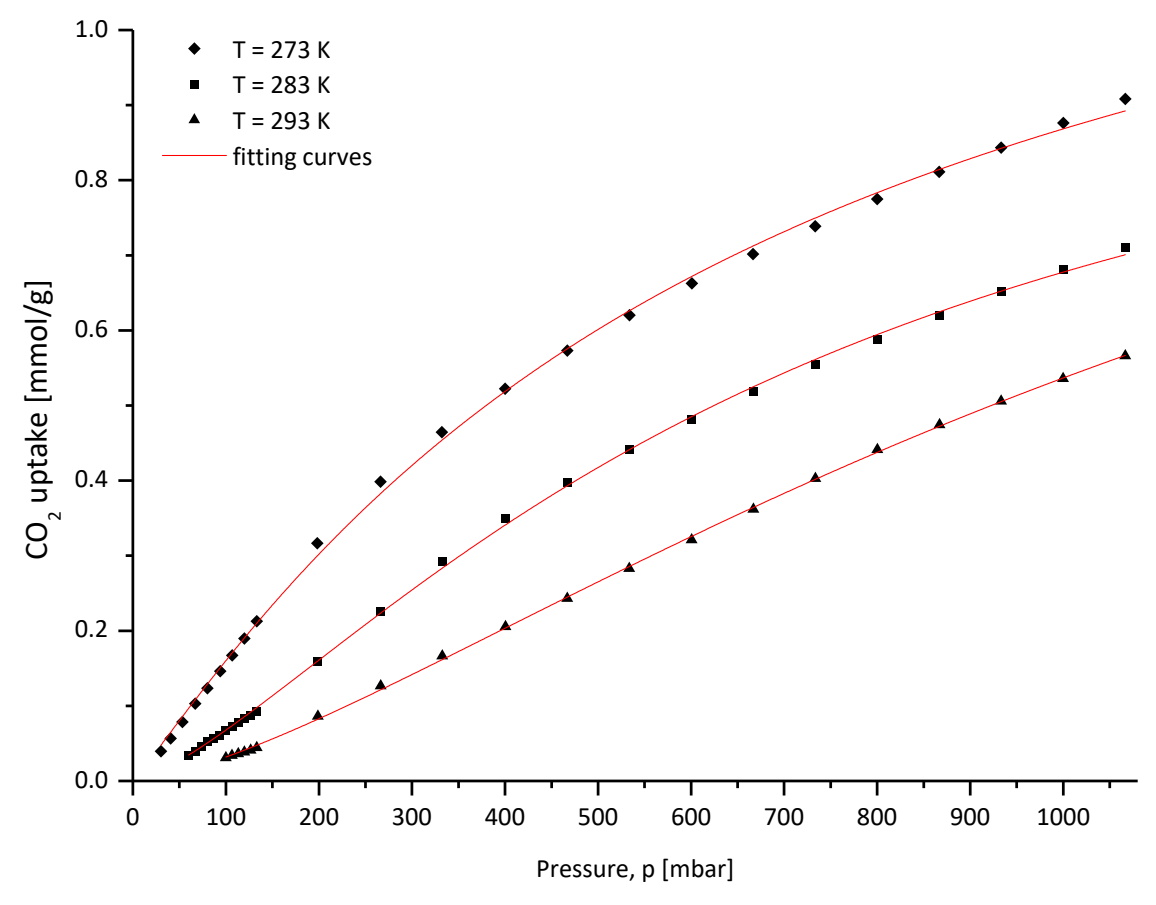

Figure S26. $\mathrm{CO}_{2}$ isotherms for 1 at 273, 283 and $293 \mathrm{~K}$ fitted with Langmuir-Freundlich model curves.

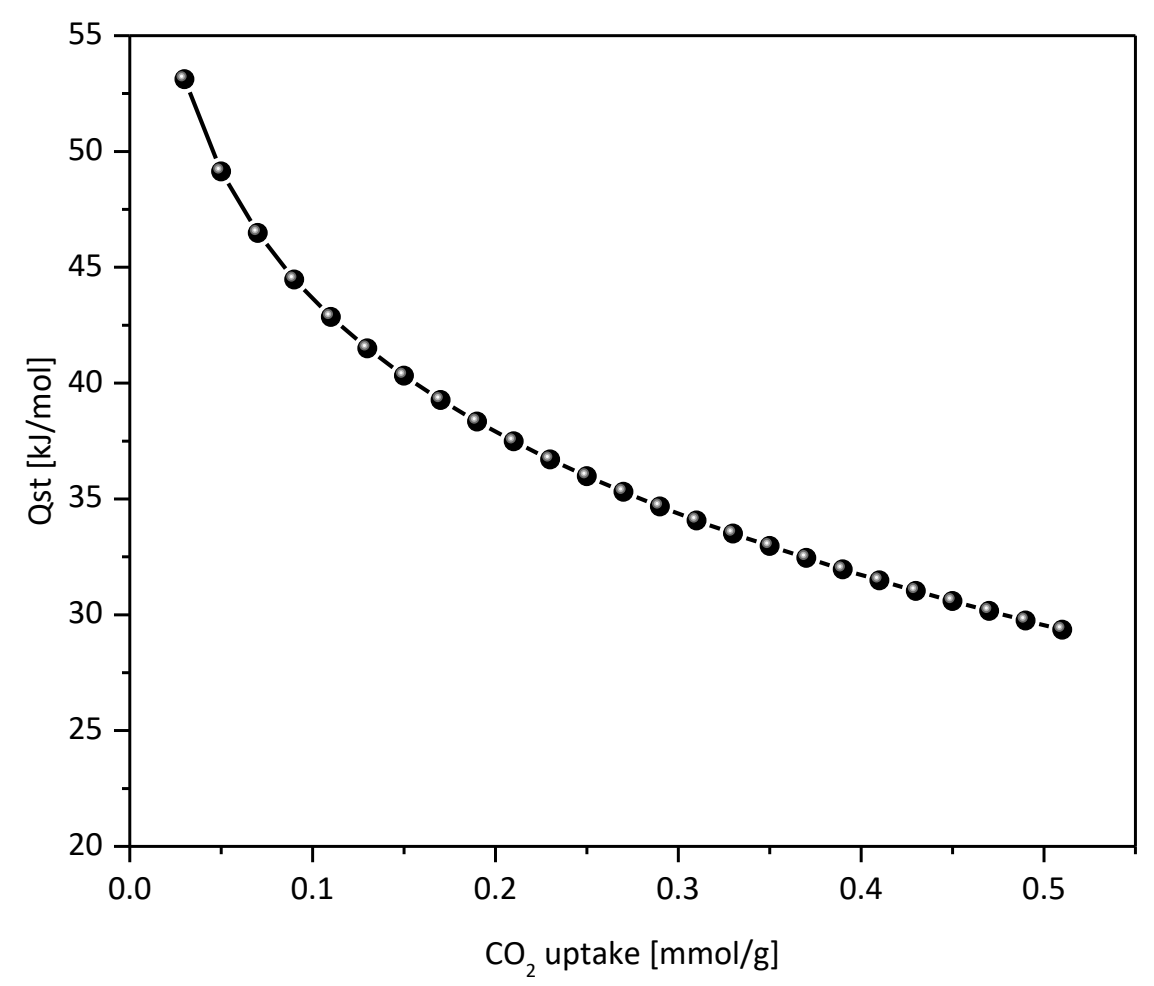

Figure S27. The $\mathrm{CO}_{2}$ isosteric heat of adsorption plot for $\mathbf{1}$. 


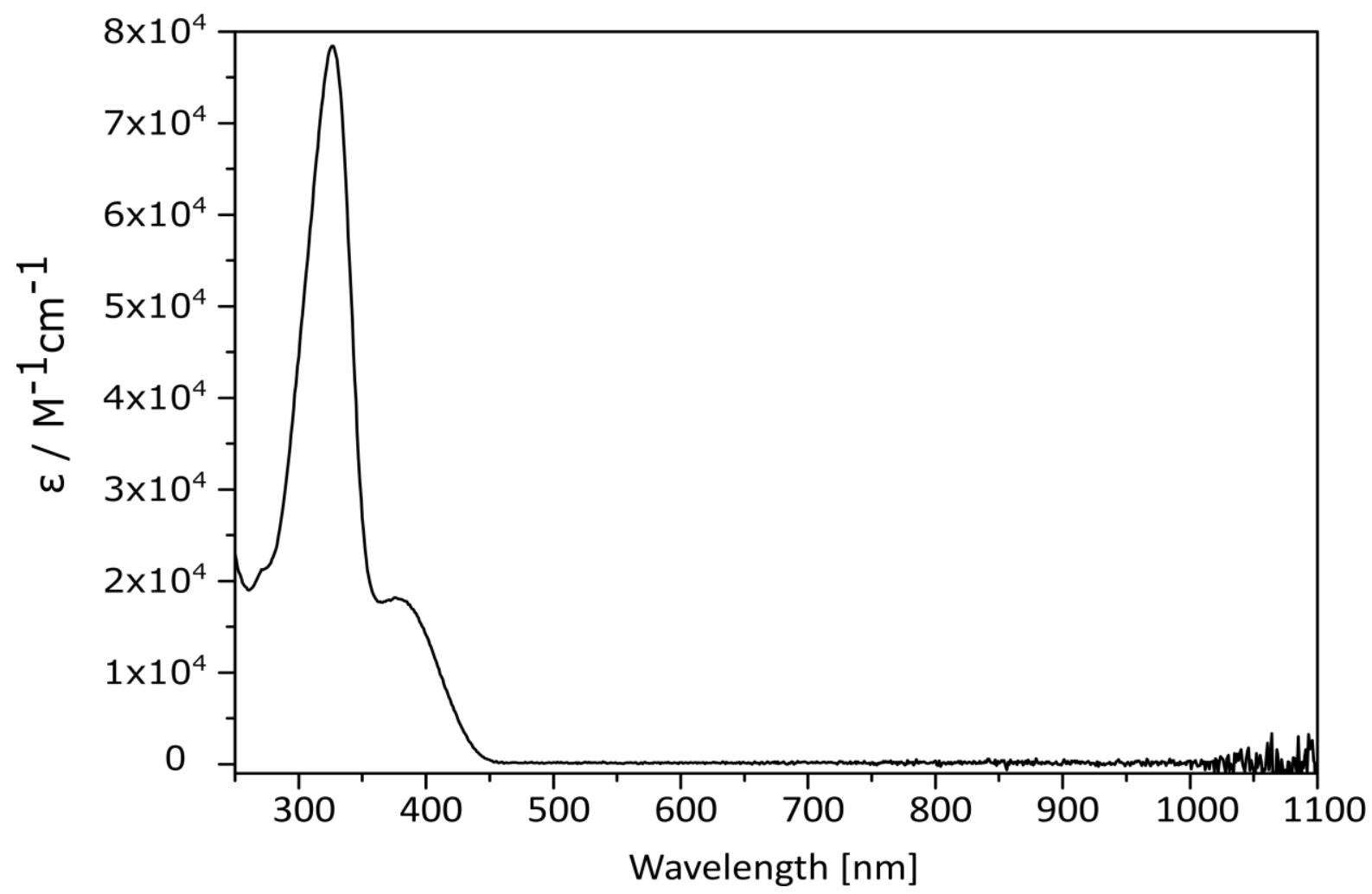

Figure S28. Absorption spectrum of 1 in dichloromethane (1 cm path length).

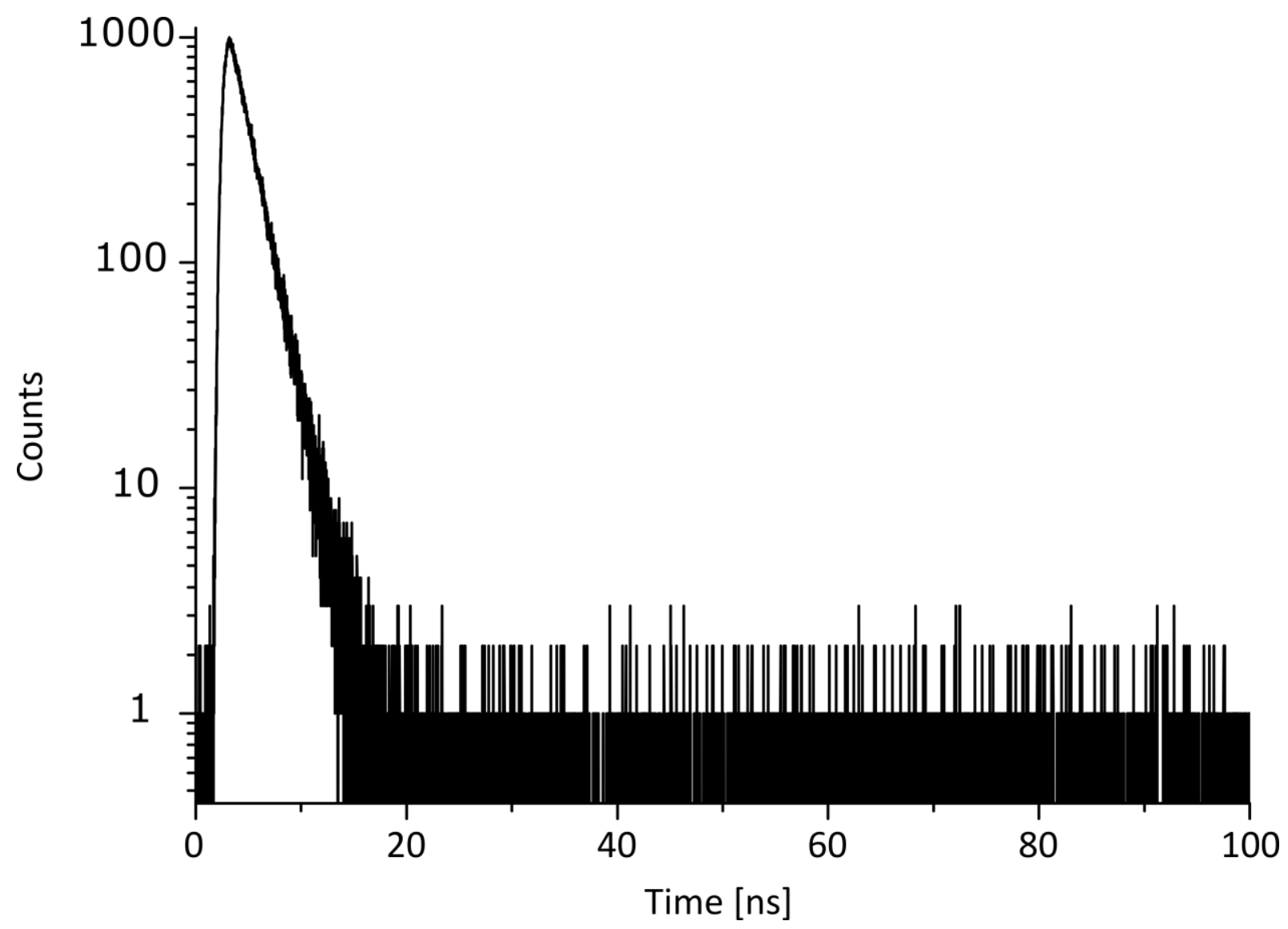

Figure S29. Fluorescence decay traces of 1 in dichloromethane $\left(\lambda_{\mathrm{em}}=490 \mathrm{~nm}\right)$. 


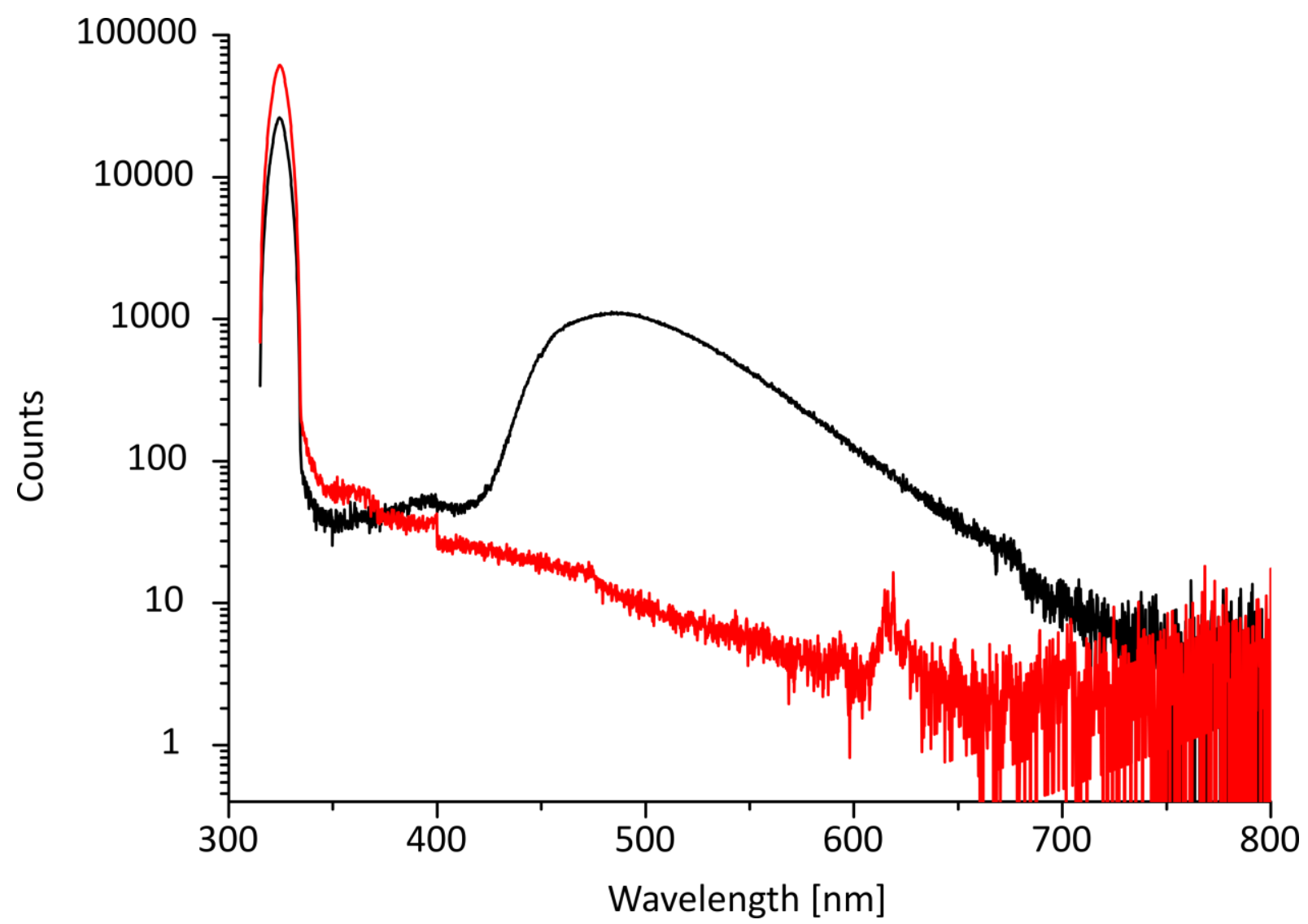

Figure S30. Spectra used for determination of the fluorescence quantum yield for compound $\mathbf{1}$ (black), solvent (red). Excitation range: 315.00 to $335.20 \mathrm{~nm}$; luminescence range: 375.00 to $800.00 \mathrm{~nm}$. QY = $33.45 \%$. 


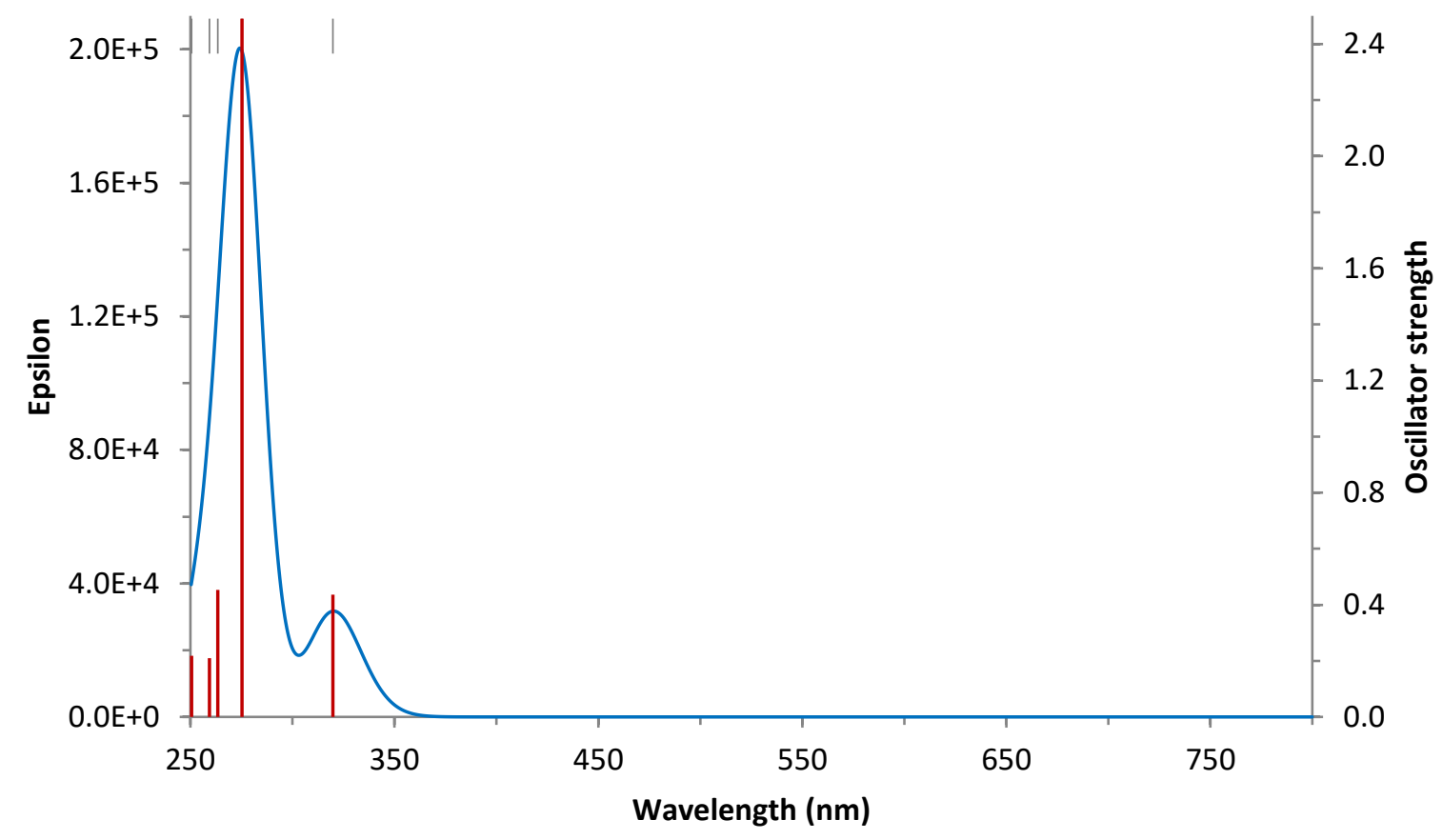

Figure S31. Simulated electronic absorption spectrum of 1 (TDA/PCM(acetone)/CAM-B3LYP-GD3BJ/6$31 G(d, p))$.

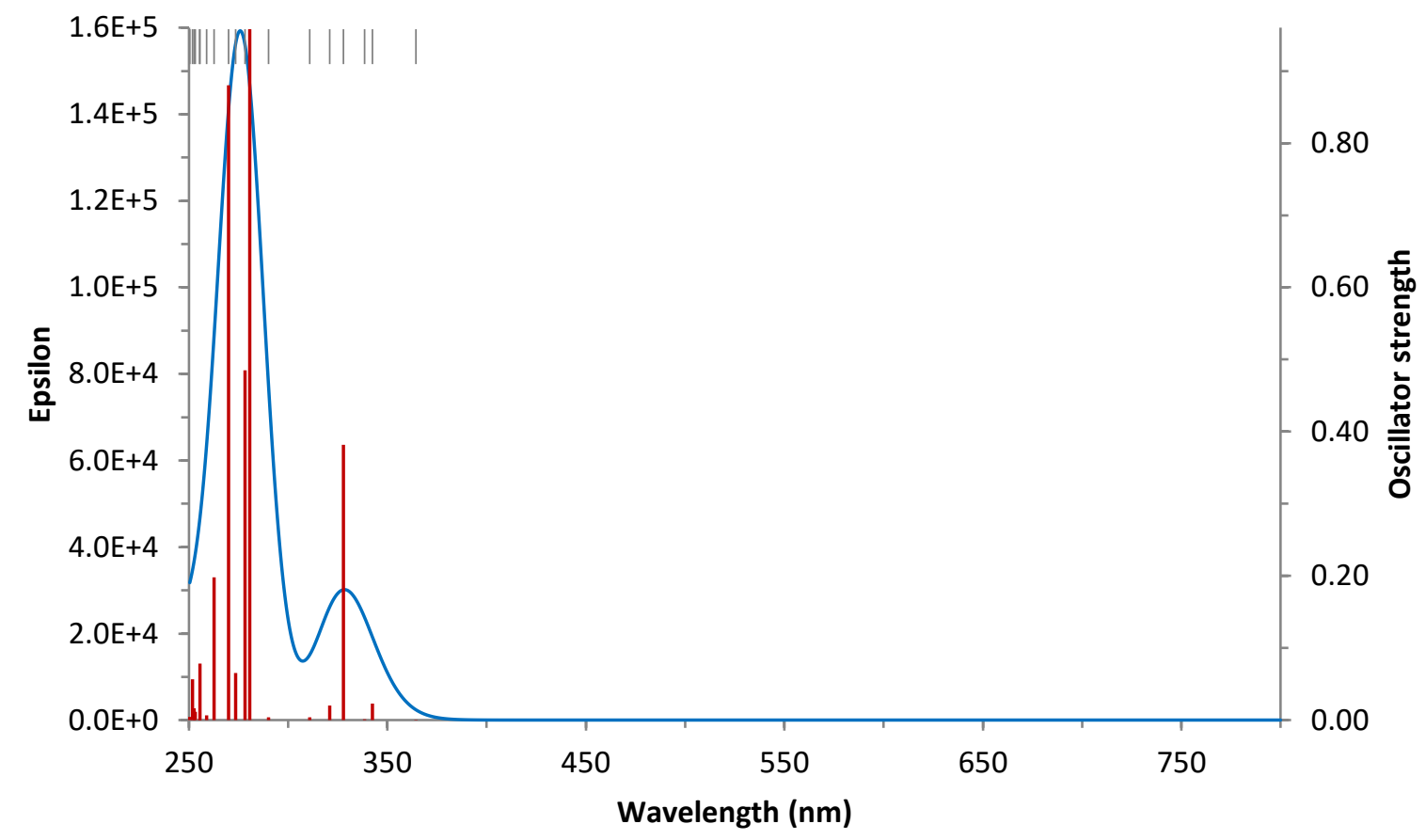

Figure S32. Simulated electronic absorption spectrum of [1دAQ] (TDA/PCM(acetone)/CAM-B3LYPGD3BJ/6-31G(d,p)). 


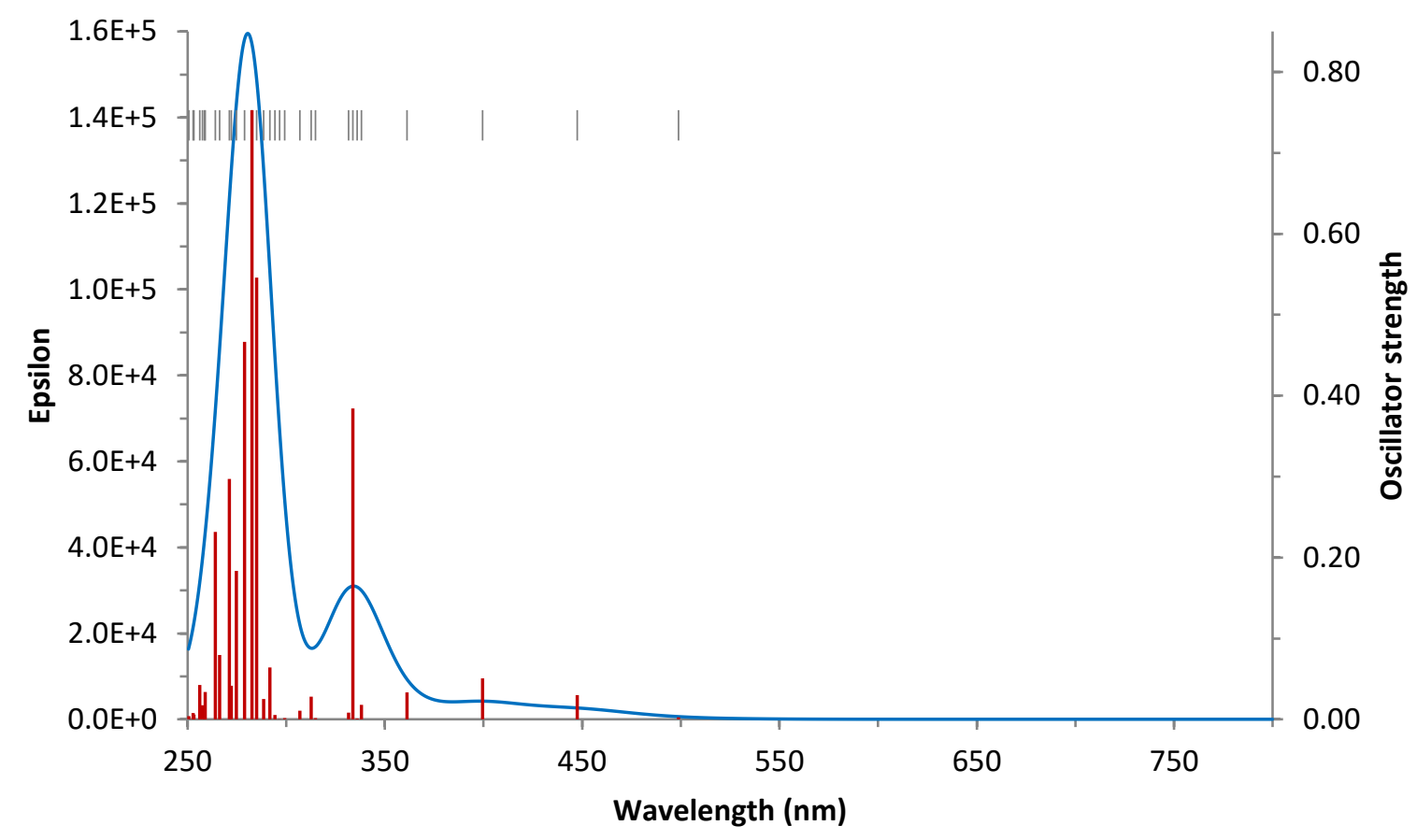

Figure S33. Simulated electronic absorption spectrum of [1つMA $\left.{ }^{+}\right]$(TDA/PCM(acetone)/CAM-B3LYPGD3BJ/6-31G(d,p)).

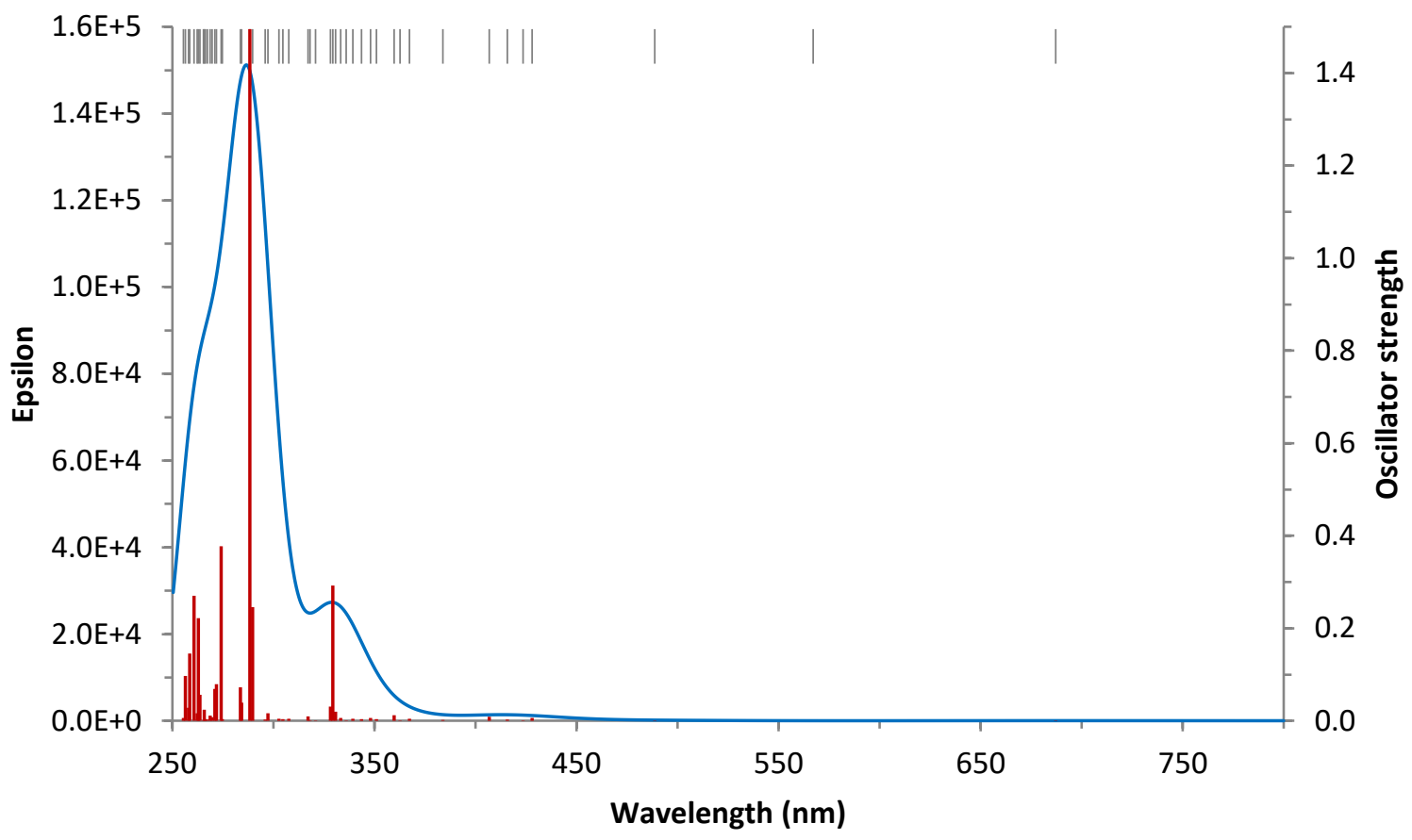

Figure S34. Simulated electronic absorption spectrum of [1 $\left.\supset \mathrm{DQ}^{2+}\right]$ (TDA/PCM(acetone)/CAM-B3LYPGD3BJ/6-31G(d,p)). 


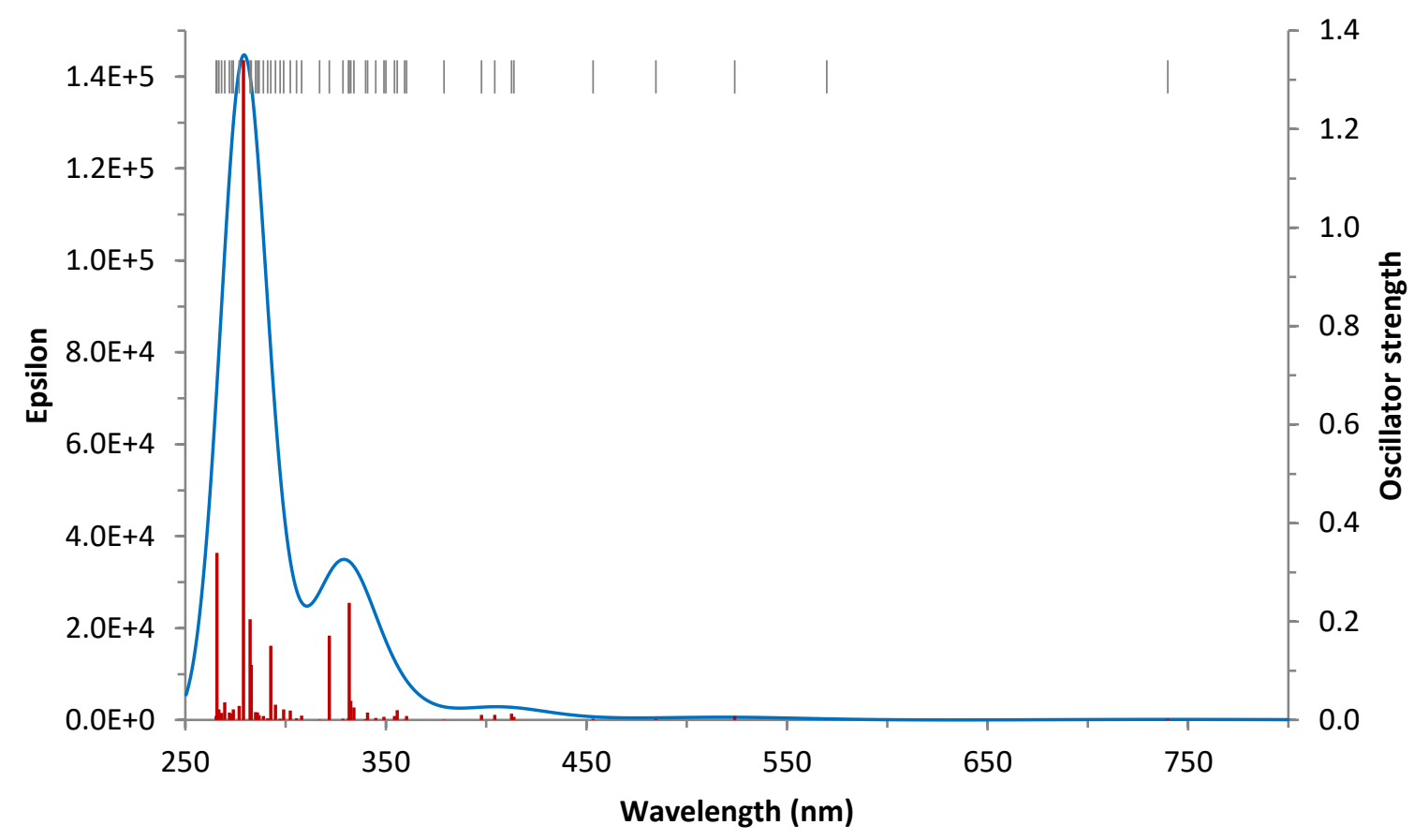

Figure S35. Simulated electronic absorption spectrum of [1 $\left.\supset \mathrm{PQ}^{2+}\right]$ (TDA/PCM(acetone)/CAM-B3LYPGD3BJ/6-31G(d,p)). 


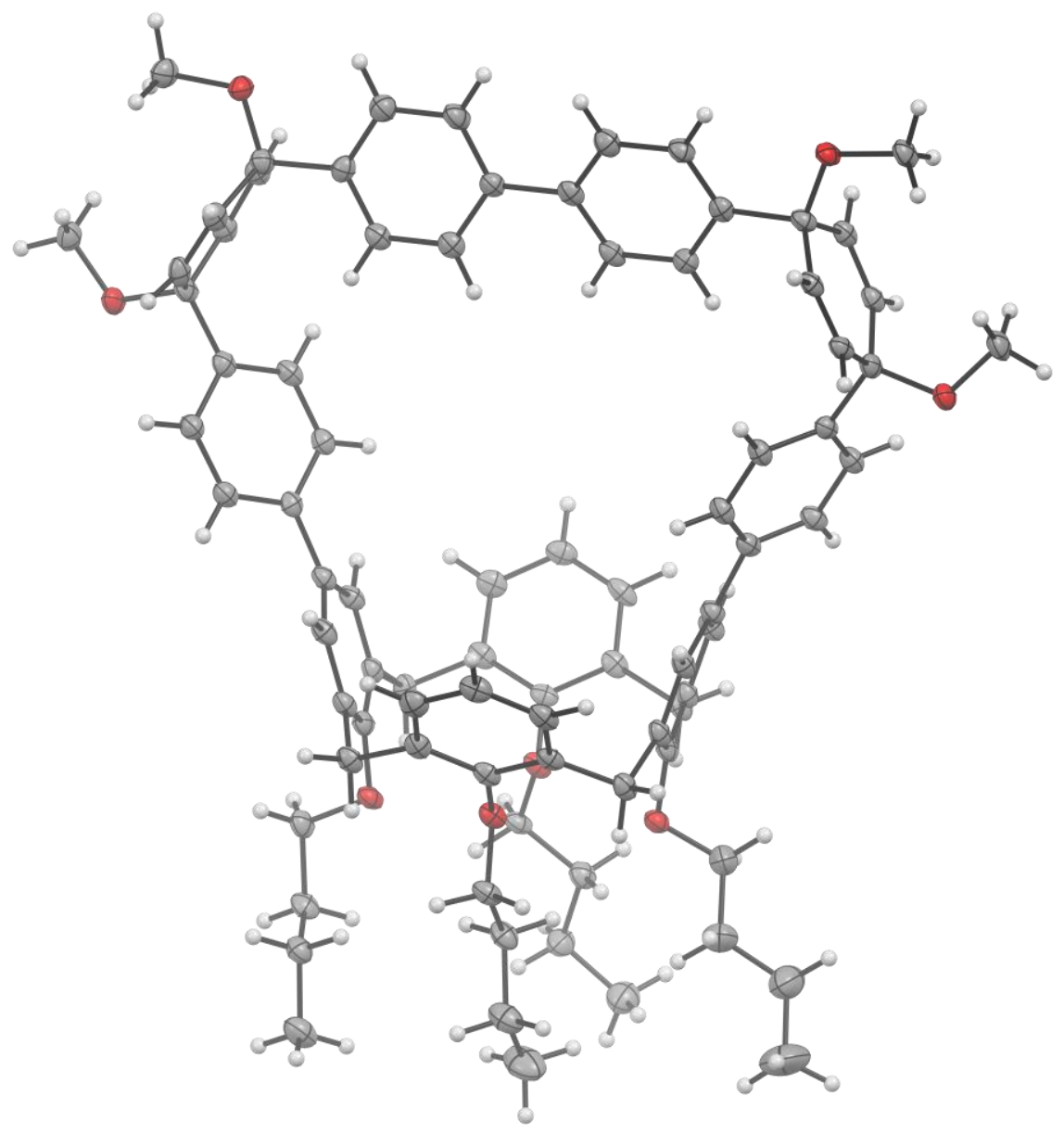

Figure S36. Crystal structure of $\mathbf{5} \cdot \mathrm{C}_{6} \mathrm{H}_{14} \cdot \mathrm{H}_{2} \mathrm{O}$. Solvent molecules are removed for clarity. 


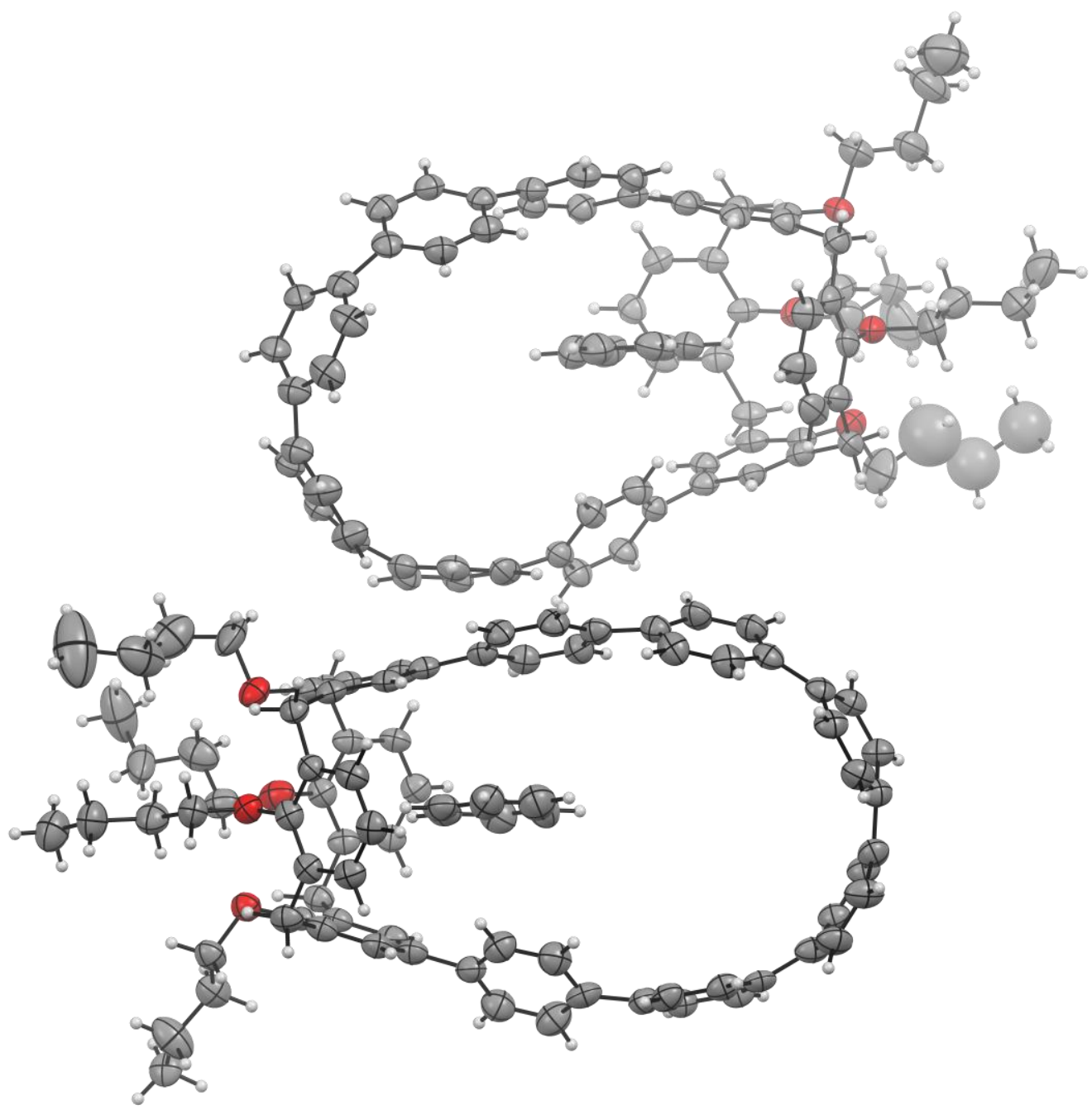

Figure S37. Crystal structure of $\mathbf{1} \cdot 3 \mathrm{C}_{6} \mathrm{H}_{6}$. Solvent molecules and disorder positions are removed for clarity. 


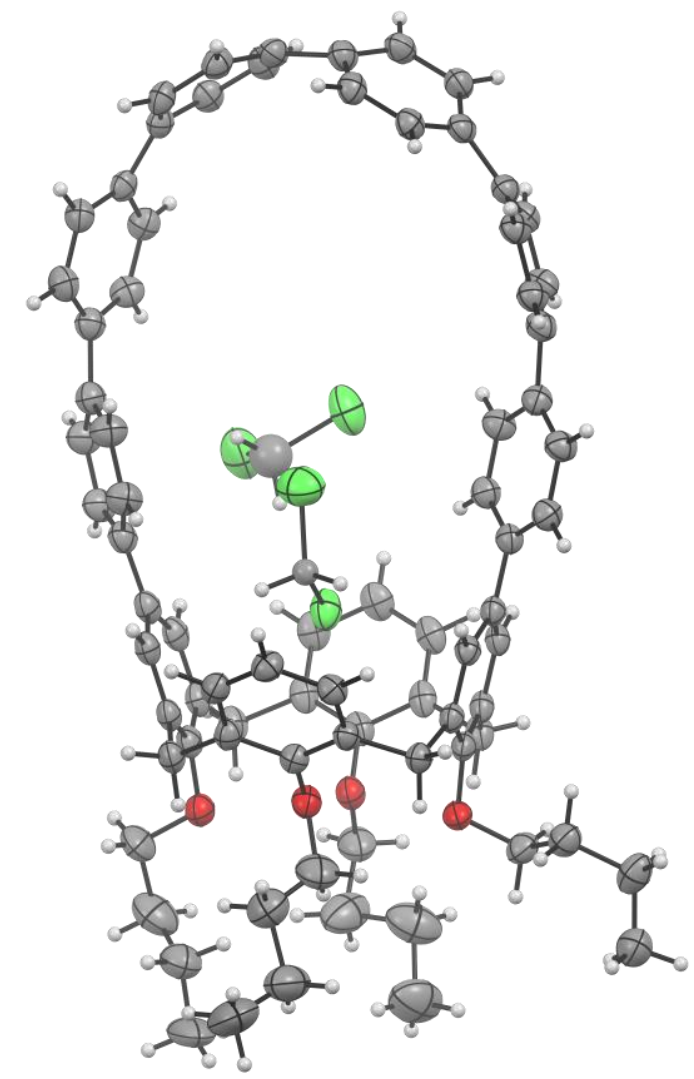

Figure S38. Crystal structure of $\mathbf{1} \cdot 3.2 \mathrm{CH}_{2} \mathrm{Cl}_{2}$. Solvent molecules and disorder positions are removed for clarity. 


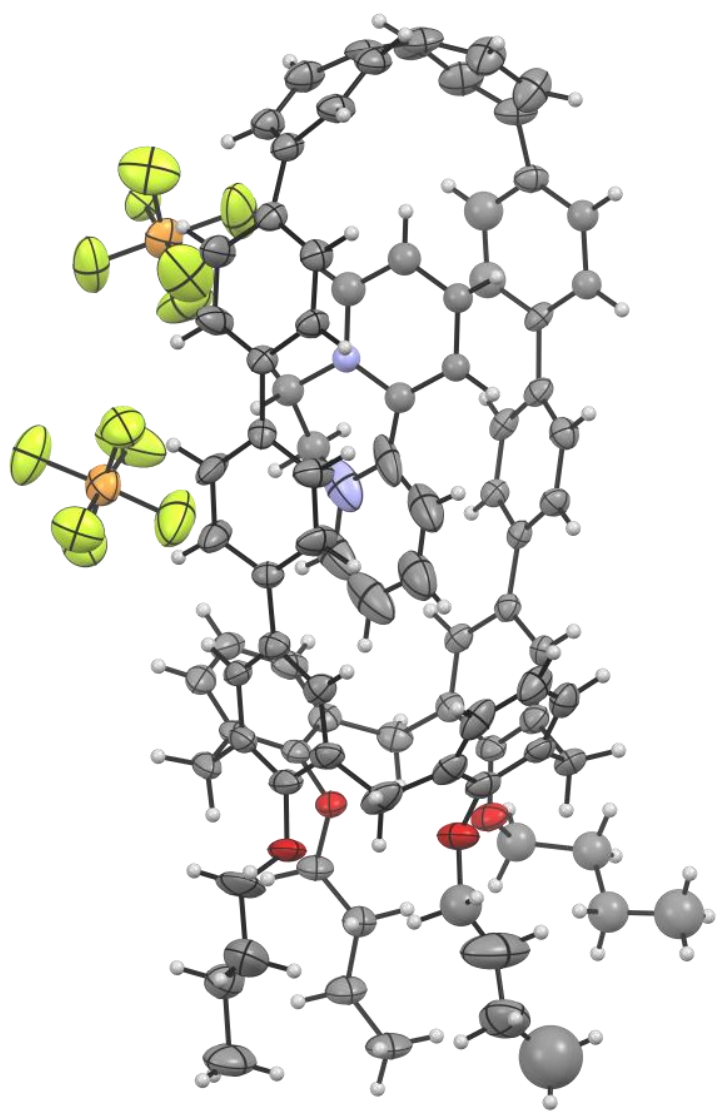

Figure S39. Crystal structure of $\left[1 \supset \mathrm{DQ}^{2+}\right]\left[\mathrm{PF}_{6}{ }^{-}\right]_{2} \cdot \mathrm{C}_{3} \mathrm{H}_{6} \mathrm{O}$. Solvent molecules and disorder positions are removed for clarity. 


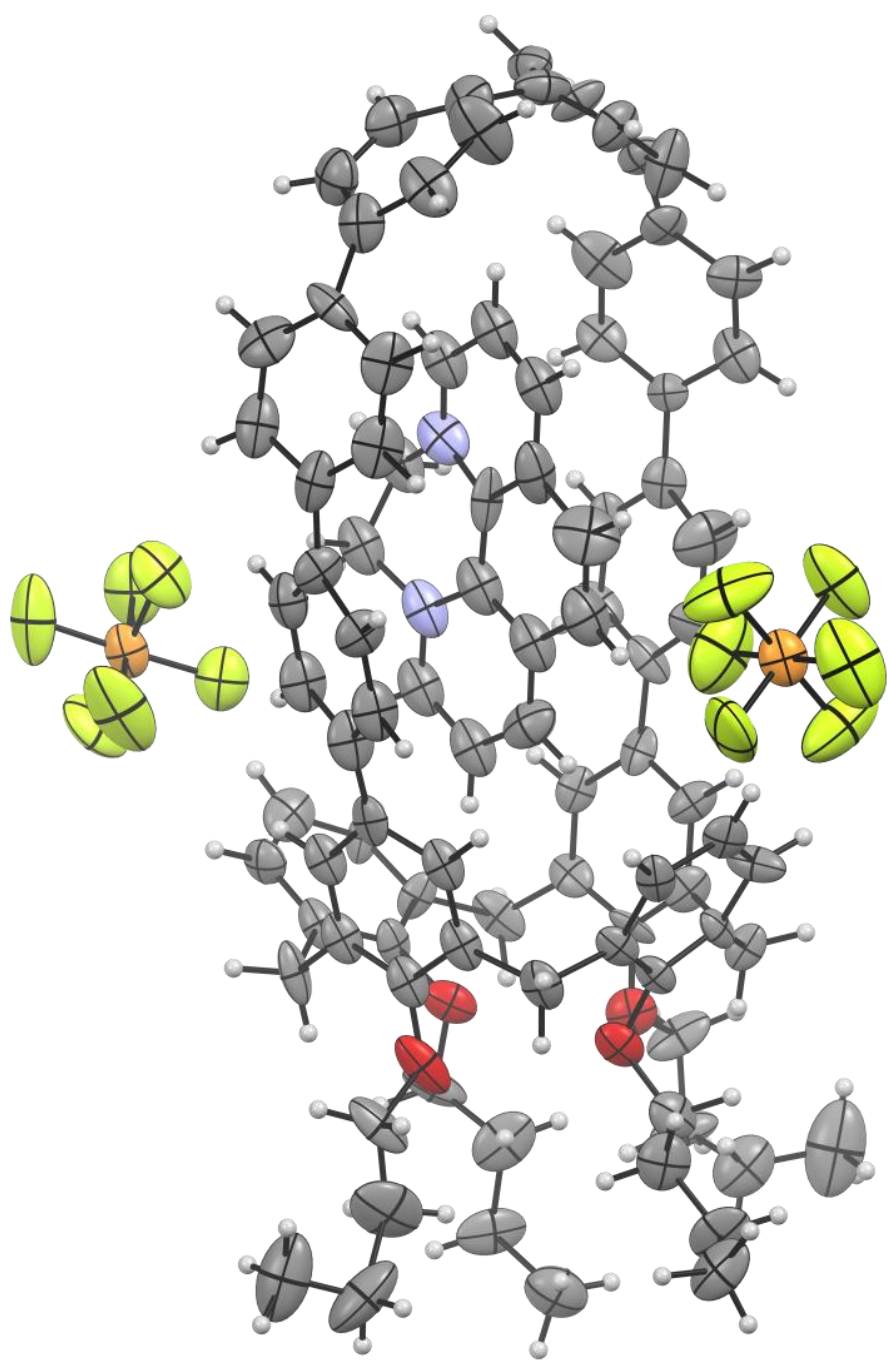

Figure S40. Crystal structure of $\left[1 \mathrm{PPQ}^{2+}\right]\left[\mathrm{PF}_{6}{ }^{-}\right]_{2} \cdot \mathrm{C}_{3} \mathrm{H}_{6} \mathrm{O}$. Solvent molecules and disorder positions are removed for clarity. 


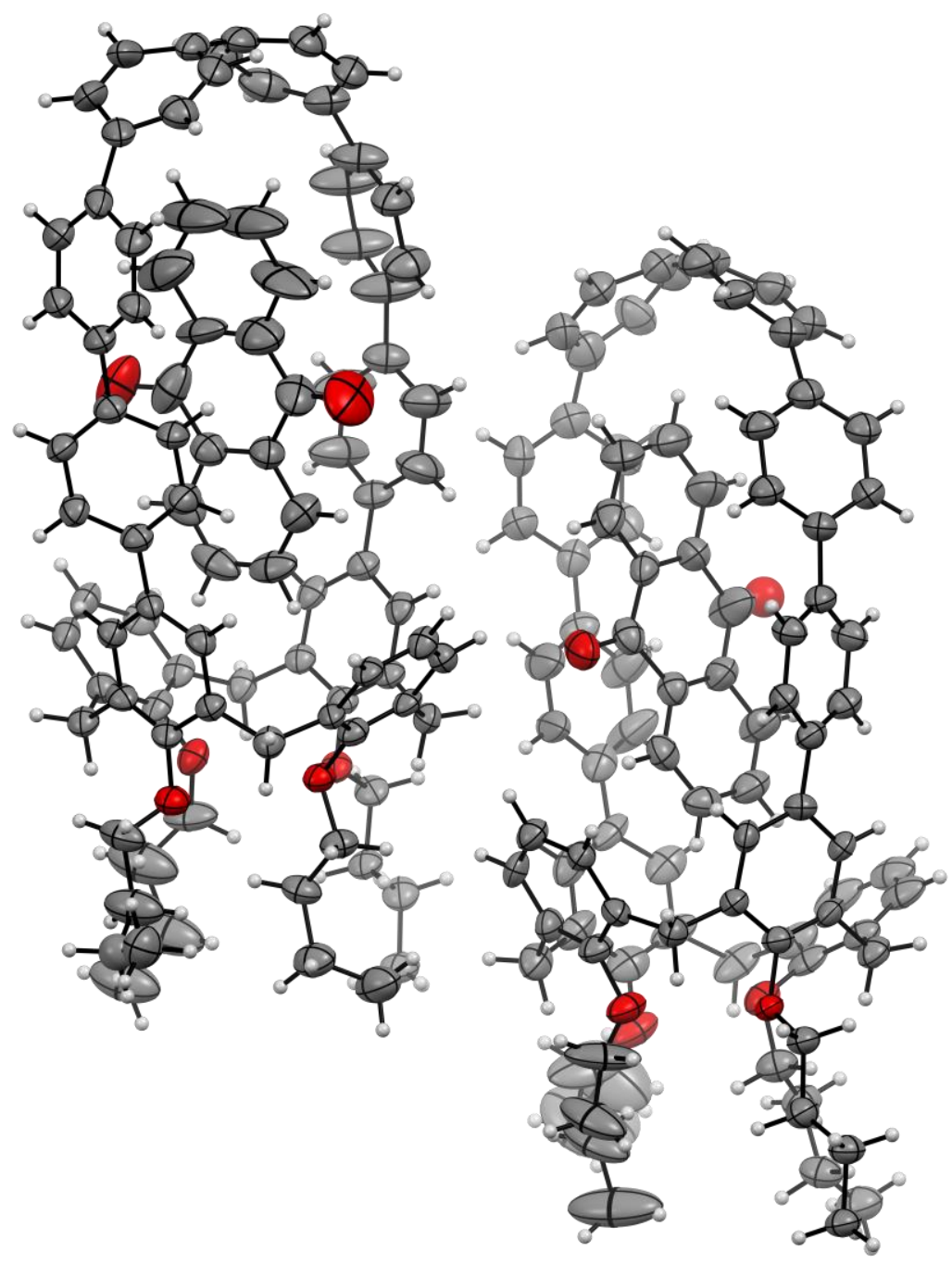

Figure S41. Crystal structure of $[1 \supset \mathrm{AQ}] \cdot 2.5 \mathrm{CH}_{4} \mathrm{O}$. Solvent molecules and disorder positions are removed for clarity. 
Additional Tables 
Table S1. Association constants for host-guest complexes of $\mathbf{1}^{a}$.

\begin{tabular}{|c|c|c|c|c|c|c|}
\hline Guest & Model & $K_{11}$ & & $K_{21}$ & & SSR \\
\hline & & optimized & error & optimized & error & \\
\hline $\mathrm{DQ}^{b}$ & $2: 1^{d}$ & $6.0337 \cdot 10^{2}$ & $2.23 \cdot 10^{0}$ & $3.3631 \cdot 10^{1}$ & $3.40 \cdot 10^{-1}$ & $2.65 \cdot 10^{-5}$ \\
\hline $\mathrm{DQ}^{b}$ & $1: 1^{e}$ & $3.5569 \cdot 10^{2}$ & $1.21 \cdot 10^{0}$ & & & $7.54 \cdot 10^{-4}$ \\
\hline $\mathrm{PQ}^{b}$ & $2: 1^{f}$ & $1.4295 \cdot 10^{3}$ & $1.34 \cdot 10^{1}$ & $1.7859 \cdot 10^{2}$ & $3.56 \cdot 10^{0}$ & $1.88 \cdot 10^{-4}$ \\
\hline $\mathrm{PQ}^{b}$ & $1: 1^{g}$ & $7.1878 \cdot 10^{2}$ & $2.72 \cdot 10^{0}$ & & & $1.72 \cdot 10^{-3}$ \\
\hline $\mathrm{MA}^{b}$ & $2: 1^{h}$ & $5.9187 \cdot 10^{3}$ & $7.18 \cdot 10^{1}$ & $4.3457 \cdot 10^{2}$ & $1.439 \cdot 10^{1}$ & $6.07 \cdot 10^{-5}$ \\
\hline $\mathrm{MA}^{b}$ & $1: 1^{i}$ & $4.3728 \cdot 10^{3}$ & $4.46 \cdot 10^{1}$ & & & $1.03 \cdot 10^{-3}$ \\
\hline $\mathrm{AQ}^{c}$ & $1: 1^{j}$ & $1.9679 \cdot 10^{1}$ & $1.9 \cdot 10^{-2}$ & & & $2.06 \cdot 10^{-5}$ \\
\hline
\end{tabular}

${ }^{a}$ based on ${ }^{1} \mathrm{H}$ NMR titration data $(300 \mathrm{~K}) .{ }^{b}$ in acetone- $-\mathrm{d}_{6},{ }^{c}$ in $\mathrm{CD}_{2} \mathrm{Cl}_{2} .{ }^{d}$ Figure S7. ${ }^{e}$ Figure S6. ${ }^{f}$ Figure S11. ${ }^{g}$ Figure S10. ${ }^{n}$ Figure S15. ' Figure S14. ${ }^{\text {Figure }}$ S18 .

Table S2. The BET fitting parameters derived from the $\mathrm{CO}_{2}$ isotherm for 1 .

\begin{tabular}{cc}
\hline Parameter & Value \\
\hline Slope & $0.0596 \pm 0.0004 \mathrm{~g} / \mathrm{cm}^{3} \mathrm{STP}$ \\
Y-intercept & $0.000350 \pm 0.000025 \mathrm{~g} / \mathrm{cm}^{3}$ STP \\
Correlation & 0.9998 \\
coefficient & $63.7 \pm 0.4 \mathrm{~m}^{2} / \mathrm{g}$ \\
BET surface area & 171 \\
C &
\end{tabular}

Table S3. Single-site Langmuir-Freudlich parameters for adsorption of $\mathrm{CO}_{2}$ in $\mathbf{1}$. These parameters were determined by fitting adsorption isotherms for temperatures ranging from 273 to $293 \mathrm{~K}$.

\begin{tabular}{cccc}
\hline & $\mathrm{T}=273 \mathrm{~K}$ & $\mathrm{~T}=283 \mathrm{~K}$ & $\mathrm{~T}=293 \mathrm{~K}$ \\
\hline$q_{\text {sat }}$ & $1.438 \pm 0.059$ & $1.103 \pm 0.025$ & $1.33 \pm 0.06$ \\
$K$ & $8.43 \cdot 10^{-4} \pm 9.4 \cdot 10^{-5}$ & $1.09 \cdot 10^{-4} \pm 1.0 \cdot 10^{-5}$ & $3.16 \cdot 10^{-5} \pm 3.1 \cdot 10^{-6}$ \\
$n$ & $1.09 \pm 0.03$ & $1.39 \pm 0.02$ & $1.44 \pm 0.02$ \\
\hline
\end{tabular}


Table S4. Computational data.

\begin{tabular}{|c|c|c|c|c|c|c|c|c|c|c|}
\hline File name $^{[a]}$ & Formula & vel of theory & $\begin{array}{c}\text { SCF E } E^{[b]} \\
\text { a.u. }\end{array}$ & $\begin{array}{c}\text { ZPV[c] } \\
\text { a.u. }\end{array}$ & $\begin{array}{c}\text { lowest } \\
\left.\text { freq. }{ }^{[d]}\right] \\
\mathrm{cm}^{-1}\end{array}$ & $\begin{array}{l}H^{[e]} \\
\text { a.u. }\end{array}$ & $\begin{array}{l}G^{[f]} \\
\text { a.u. }\end{array}$ & $\begin{array}{c}\text { HOMO[g] } \\
\mathrm{eV}\end{array}$ & $\begin{array}{c}\text { LUMO } \\
\mathrm{eV}\end{array}$ & $\begin{array}{c}H L G\left[g^{3}\right] \\
\mathrm{eV}\end{array}$ \\
\hline 1_AQ_CAMacetone & $\mathrm{C}_{86} \mathrm{H}_{70} \mathrm{O}_{6}$ & CAM-B3LYP/6-31G(d,p) & -3768.966020 & 1.346138 & 12.49 & -3767.544062 & -3767.731012 & -6.37 & -1.06 & 5.31 \\
\hline 1_CAMacetone & $\mathrm{C}_{72} \mathrm{H}_{62} \mathrm{O}_{4}$ & CAM-B3LYP/6-31G(d,p) & -3080.440368 & 1.160906 & 17.68 & -3079.216311 & -3079.375733 & -6.39 & -0.30 & 6.10 \\
\hline 1_CO2_vac & $\mathrm{C}_{73} \mathrm{H}_{62} \mathrm{O}_{6}$ & B3LYP/6-31G(d,p) & -3270.940247 & 1.159592 & 17.94 & -3269.712415 & -3269.883869 & -5.03 & -1.45 & 3.58 \\
\hline 1_MA+_CAMacetone & $\mathrm{C}_{86} \mathrm{H}_{74} \mathrm{NO}_{4}$ & CAM-B3LYP/6-31G(d,p) & -3675.527695 & 1.390744 & 11.93 & -3674.061356 & -3674.246670 & -6.97 & -2.86 & 4.11 \\
\hline 1_PQ2+_CAMacetone & $\mathrm{C}_{86} \mathrm{H}_{74} \mathrm{~N}_{2} \mathrm{O}_{4}$ & CAM-B3LYP/6-31G(d,p) & -3730.063892 & 1.400629 & 12.78 & -3728.588312 & -3728.771517 & -7.59 & -4.34 & 3.25 \\
\hline 1_DQ2+_CAMacetone & $\mathrm{C}_{84} \mathrm{H}_{74} \mathrm{~N}_{2} \mathrm{O}_{4}$ & CAM-B3LYP/6-31G(d,p) & -3653.866914 & 1.388212 & 19.12 & -3652.404640 & -3652.584363 & -7.69 & -4.30 & 3.39 \\
\hline 1_round_vac & $\mathrm{C}_{72} \mathrm{H}_{62} \mathrm{O}_{4}$ & B3LYP/6-31G(d,p) & -3082.335748 & 1.147045 & 17.07 & -3081.124552 & -3081.286777 & -5.10 & -1.50 & 3.60 \\
\hline 1_flat_vac & $\mathrm{C}_{72} \mathrm{H}_{62} \mathrm{O}_{4}$ & B3LYP/6-31G(d,p) & -3082.337646 & 1.147246 & 17.28 & -3081.126386 & -3081.287748 & -5.05 & -1.44 & 3.61 \\
\hline L_MA+_acetone & $\mathrm{C}_{8} \mathrm{H}_{74} \mathrm{NO}_{4}$ & B3LYP/6-31G(d,p) & -3677.814276 & 1.374917 & 7.86 & -3676.362825 & -3676.550194 & -5.71 & -3.84 & 1.87 \\
\hline
\end{tabular}

[a] Structure code (see the zip file for Cartesian coordinates). [b] SCF electronic energy. [c] Zero-point vibrational energy. [d] Lowest vibrational frequency. [e] Enthalpy, [f] Gibbs free energy. [g] Frontier orbital energies and the HOMO-LUMO gap. 
Table S5. Electronic transitions calculated for $\left[1 \supset \mathrm{MA}^{+}\right]$using the TDA/PCM(acetone)/CAM-B3LYPGD3BJ/6-31G(d,p) level of theory.

\begin{tabular}{|c|c|c|c|c|}
\hline No. & $\begin{array}{l}\text { Energy } \\
\left(\mathrm{cm}^{-1}\right)\end{array}$ & $\begin{array}{c}\lambda \\
(\mathrm{nm})\end{array}$ & $f^{[a]}$ & $\begin{array}{c}\text { Major } \\
\text { excitations }^{[b]}\end{array}$ \\
\hline 1 & 20049 & 498.8 & 0.002 & HOMO»LUMO (94\%) \\
\hline 2 & 22344 & 447.5 & 0.030 & H-1»LUMO (97\%) \\
\hline 3 & 25033 & 399.5 & 0.051 & H-2»LUMO (92\%) \\
\hline 4 & 27678 & 361.3 & 0.033 & $\begin{array}{l}\text { H-7»LLUMO (44\%) } \\
\text { H-4»LUMO (28\%) }\end{array}$ \\
\hline 5 & 29577 & 338.1 & 0.018 & $\begin{array}{l}\text { H-6»LUMO (10\%) } \\
\text { H-5»LUMO (68\%) } \\
\text { H-4»LUMO (14\%) }\end{array}$ \\
\hline 6 & 29774 & 335.9 & 0.001 & H-3»LUMO (90\%) \\
\hline 7 & 29963 & 333.7 & 0.384 & HOMO»L+1 (80\%) \\
\hline 8 & 30153 & 331.6 & 0.008 & $\begin{array}{l}\text { H-7» LUMO (23\%) } \\
\text { H-4»LUMO (54\%) }\end{array}$ \\
\hline 9 & 31776 & 314.7 & 0.002 & $\begin{array}{l}\text { H-6»LUMO (76\%) } \\
\text { H-5»LUMO (11\%) }\end{array}$ \\
\hline 10 & 31978 & 312.7 & 0.028 & $\begin{array}{l}\text { H-15»LUMO (28\%) } \\
\text { H-10»LUMO (23\%) }\end{array}$ \\
\hline 11 & 32585 & 306.9 & 0.011 & H-14»LUMO (59\%) \\
\hline 12 & 33420 & 299.2 & 0.002 & $\begin{array}{l}\text { H-15»LUMO (12\%) } \\
\text { H-9»LUMO (12\%) } \\
\text { H-8»LUMO (53\%) }\end{array}$ \\
\hline 13 & 33708 & 296.7 & 0.000 & $\begin{array}{l}\text { H-16»LUMO (19\%) } \\
\text { H-15»LUMO (30\%) } \\
\text { H-9»LUMO (12\%) }\end{array}$ \\
\hline 14 & 33975 & 294.3 & 0.006 & $\begin{array}{l}\text { H-12»LUMO (11\%) } \\
\text { H-11»LUMO (23\%) } \\
\text { H-9»LUMO (30\%) }\end{array}$ \\
\hline 15 & 34289 & 291.6 & 0.064 & $\begin{array}{l}\text { H-13»LUMO (31\%) } \\
\text { H-10»LUMO (25\%) }\end{array}$ \\
\hline 16 & 34650 & 288.6 & 0.025 & $\begin{array}{l}\text { H-10»LUMO (16\%) } \\
\text { H-9»LUMO (33\%) } \\
\text { H-8»LUMO (25\%) }\end{array}$ \\
\hline 17 & 35081 & 285.1 & 0.546 & $\begin{array}{l}\text { H-13»LUMO (43\%) } \\
\text { HOMO»L+3 (10\%) }\end{array}$ \\
\hline 18 & 35379 & 282.7 & 0.753 & $\begin{array}{l}\text { H-12»LUMO (14\%) } \\
\text { HOMO»L+3 (11\%) }\end{array}$ \\
\hline 19 & 35855 & 278.9 & 0.466 & H-12»LUMO (27\%) \\
\hline 20 & 36407 & 274.7 & 0.183 & $\begin{array}{l}\text { HOMO»L+2 (72\%) } \\
\text { HOMO»L+3 (10\%) }\end{array}$ \\
\hline 21 & 36749 & 272.1 & 0.041 & $\begin{array}{l}\text { H-17»LUMO (12\%) } \\
\text { H-14»LUMO (11\%) } \\
\text { H-12»LUMO (10\%) } \\
\text { H-11»LUMO (41\%) }\end{array}$ \\
\hline 22 & 36868 & 271.2 & 0.297 & $\begin{array}{l}\text { H-11»L+1 (11\%) } \\
\text { HOMO»L+7 (28\%) } \\
\text { HOMO»L+8 (14\%) }\end{array}$ \\
\hline 23 & 37565 & 266.2 & 0.080 & $\begin{array}{l}\text { H-25»LUMO (40\%) } \\
\text { H-21»LUMO (10\%) } \\
\text { H-19»LUMO (15\%) } \\
\text { H-12»LUMO (12\%) }\end{array}$ \\
\hline 24 & 37877 & 264.0 & 0.232 & $\begin{array}{l}H-2 » L+1(19 \%) \\
H-1 » L+2(10 \%) \\
H-1 » L+3(22 \%) \\
H O M O » L+4(18 \%)\end{array}$ \\
\hline
\end{tabular}

\begin{tabular}{|c|c|c|c|c|}
\hline No. & $\begin{array}{l}\text { Energy } \\
\left(\mathrm{cm}^{-1}\right)\end{array}$ & $\begin{array}{c}\lambda \\
(\mathrm{nm})\end{array}$ & $f^{\text {fa] }}$ & $\begin{array}{c}\text { Major } \\
\text { excitations }^{[b]}\end{array}$ \\
\hline 25 & 38625 & 258.9 & 0.034 & $\begin{array}{l}\mathrm{H}-25 » \mathrm{LUMO}(16 \%) \\
\mathrm{H}-20 » \mathrm{LUMO}(12 \%) \\
\mathrm{H}-19 » \mathrm{LUMO}(33 \%)\end{array}$ \\
\hline 26 & 38678 & 258.5 & 0.007 & $\begin{array}{l}\mathrm{H}-17 » \mathrm{LUMO}(34 \%) \\
\mathrm{H}-16 » \mathrm{LUMO}(43 \%)\end{array}$ \\
\hline 27 & 38829 & 257.5 & 0.017 & $H-1 » L+2(58 \%)$ \\
\hline 28 & 39041 & 256.1 & 0.043 & HOMO»L+11 (16\%) \\
\hline 29 & 39505 & 253.1 & 0.006 & \\
\hline 30 & 39558 & 252.8 & 0.008 & $\begin{array}{l}\mathrm{H}-2 » \mathrm{~L}+2(10 \%) \\
\text { HOMO»L+3 (11\%) }\end{array}$ \\
\hline 31 & 39888 & 250.7 & 0.004 & $\begin{array}{l}\mathrm{H}-1 » \mathrm{~L}+1(23 \%) \\
\text { HOMO»L+3 (26\%) }\end{array}$ \\
\hline 32 & 40401 & 247.5 & 0.004 & $H-1 » L+2(16 \%)$ \\
\hline 33 & 40707 & 245.7 & 0.003 & $\begin{array}{l}\mathrm{H}-16 » \mathrm{~L}+1(12 \%) \\
\text { HOMO»L+18 (13\%) }\end{array}$ \\
\hline 34 & 40876 & 244.6 & 0.007 & $\mathrm{H}-18 » \mathrm{LUMO}(15 \%)$ \\
\hline 35 & 40947 & 244.2 & 0.014 & H-18»LUMO (50\%) \\
\hline 36 & 41095 & 243.3 & 0.003 & \\
\hline 37 & 41302 & 242.1 & 0.025 & $\begin{array}{l}\text { H-24»LUMO (37\%) } \\
\text { H-20»LUMO (20\%) } \\
\text { H-18»LUMO (23\%) }\end{array}$ \\
\hline 38 & 41603 & 240.4 & 0.001 & $\begin{array}{l}\mathrm{H}-5 » \mathrm{~L}+1(13 \%) \\
\mathrm{H}-2 » \mathrm{~L}+2(12 \%) \\
\mathrm{H}-2 » \mathrm{~L}+3(14 \%) \\
\mathrm{H}-1 » \mathrm{~L}+4(11 \%)\end{array}$ \\
\hline 39 & 41859 & 238.9 & 0.003 & $\begin{array}{l}H-2 » L+2(32 \%) \\
H-2 » L+3(11 \%) \\
\text { HOMO»L+5 (20\%) }\end{array}$ \\
\hline 40 & 42346 & 236.1 & 0.004 & $\begin{array}{l}\mathrm{H}-21 » \mathrm{LUMO}(32 \%) \\
\mathrm{H}-20 » \mathrm{LUMO}(20 \%) \\
\mathrm{H}-19 » \text { LUMO (33\%) }\end{array}$ \\
\hline 41 & 42423 & 235.7 & 0.012 & $\begin{array}{l}\text { H-2»L+2 (13\%) } \\
\text { HOMO»L+5 (35\%) }\end{array}$ \\
\hline 42 & 42938 & 232.9 & 0.026 & \\
\hline 43 & 43127 & 231.9 & 0.019 & \\
\hline 44 & 43218 & 231.4 & 0.002 & $\begin{array}{l}\text { H-2»L+1 (34\%) } \\
\text { HOMO»L+4 (35\%) }\end{array}$ \\
\hline 45 & 43659 & 229.0 & 0.004 & $\begin{array}{l}\mathrm{H}-22 » \mathrm{LUMO}(72 \%) \\
\mathrm{H}-20 » \mathrm{LUMO}(12 \%)\end{array}$ \\
\hline 46 & 44070 & 226.9 & 0.014 & $\begin{array}{l}\mathrm{H}-2 » \mathrm{~L}+1(10 \%) \\
\mathrm{H}-1 » \mathrm{~L}+3(36 \%) \\
\mathrm{H}-1 » \mathrm{~L}+5(13 \%) \\
\text { HOMO»L+4 (18\%) }\end{array}$ \\
\hline 47 & 44579 & 224.3 & 0.844 & $\begin{array}{l}H-7 » L+2(11 \%) \\
H-4 » L+2(18 \%)\end{array}$ \\
\hline 48 & 44781 & 223.3 & 0.036 & $\mathrm{H}-23 » \mathrm{LUMO}(71 \%)$ \\
\hline 49 & 44875 & 222.8 & 0.590 & \\
\hline 50 & 45243 & 221.0 & 0.152 & $\begin{array}{l}\mathrm{H}-2 » \mathrm{~L}+5(13 \%) \\
\text { HOMO»L+6 (14\%) }\end{array}$ \\
\hline
\end{tabular}

[a] Oscillator strength. [b] Contributions smaller than $10 \%$ are not included. $\mathrm{H}=\mathrm{HOMO}, \mathrm{L}=$ LUMO. Orbitals are numbered consecutively regardless of possible degeneracies. 
Table S6. Electronic transitions calculated for $\left[1 \supset \mathrm{DQ}^{2+}\right]$ using the TDA/PCM(acetone)/CAM-B3LYPGD3BJ/6-31G(d,p) level of theory.

\begin{tabular}{|c|c|c|c|c|}
\hline No. & $\begin{array}{l}\text { Energy } \\
\left(\mathrm{cm}^{-1}\right)\end{array}$ & $\begin{array}{c}\lambda \\
(\mathrm{nm})\end{array}$ & $f^{[a]}$ & $\begin{array}{c}\text { Major } \\
\text { excitations }^{[b]}\end{array}$ \\
\hline 1 & 14556 & 687.0 & 0.000 & HOMO»LUMO (94\%) \\
\hline 2 & 17634 & 567.1 & 0.000 & H-1»LUMO (95\%) \\
\hline 3 & 20465 & 488.6 & 0.001 & H-2»LUMO (88\%) \\
\hline 4 & 23361 & 428.1 & 0.006 & HOMO»L+1 (85\%) \\
\hline 5 & 23611 & 423.5 & 0.001 & H-3»LUMO (87\%) \\
\hline 6 & 24050 & 415.8 & 0.003 & $\begin{array}{l}\mathrm{H}-4 » \text { \&UMO (77\%) } \\
\mathrm{H}-1 » \mathrm{~L}+1(15 \%)\end{array}$ \\
\hline 7 & 24582 & 406.8 & 0.009 & H-5»LUMO (85\%) \\
\hline 8 & 26047 & 383.9 & 0.002 & H-6»LUMO (88\%) \\
\hline 9 & 27222 & 367.3 & 0.005 & $\begin{array}{l}\text { H-9»LUMO (11\%) } \\
\text { H-8»LUMO (11\%) } \\
H-2 » L+1(10 \%) \\
H-2 » L+2(13 \%) \\
H-1 » L+2(10 \%) \\
\text { HOMO»L+2 (29\%) }\end{array}$ \\
\hline 10 & 27572 & 362.7 & 0.001 & $\begin{array}{l}H-4 » L U M O(11 \%) \\
H-1 » L+1(72 \%)\end{array}$ \\
\hline 11 & 27801 & 359.7 & 0.012 & $\begin{array}{l}\mathrm{H}-10 » \text { LUMO (37\%) } \\
\text { H-8»LUMO (37\%) }\end{array}$ \\
\hline 12 & 28490 & 351.0 & 0.004 & $\begin{array}{l}\text { H-10»LUMO (33\%) } \\
\text { H-8»LUMO (13\%) } \\
\text { HOMO»L+2 (14\%) }\end{array}$ \\
\hline 13 & 28723 & 348.2 & 0.007 & $\begin{array}{l}\text { H-9»LUMO (49\%) } \\
\text { H-8»LUMO (21\%) }\end{array}$ \\
\hline 14 & 29098 & 343.7 & 0.003 & $\begin{array}{l}\mathrm{H}-15 » L U M O(32 \%) \\
\mathrm{H}-12 » L U M O(47 \%)\end{array}$ \\
\hline 15 & 29477 & 339.3 & 0.005 & $\begin{array}{l}\mathrm{H}-15 » L U M O(39 \%) \\
\mathrm{H}-7 » \text { LUMO (35\%) }\end{array}$ \\
\hline 16 & 29755 & 336.1 & 0.000 & $\begin{array}{l}\mathrm{H}-15 » \mathrm{LUMO}(10 \%) \\
\mathrm{H}-1 » \mathrm{~L}+2(37 \%)\end{array}$ \\
\hline 17 & 30001 & 333.3 & 0.006 & $\begin{array}{l}\mathrm{H}-15 » \text { LUMO (11\%) } \\
\mathrm{H}-12 » L U M O(19 \%) \\
\mathrm{H}-7 » L \mathrm{~L} M O(24 \%) \\
\mathrm{H}-1 » \mathrm{~L}+2(15 \%)\end{array}$ \\
\hline 18 & 30231 & 330.8 & 0.020 & H-13»LUMO (77\%) \\
\hline 19 & 30359 & 329.4 & 0.292 & HOMO»L+3 (63\%) \\
\hline 20 & 30475 & 328.1 & 0.030 & $\begin{array}{l}\mathrm{H}-14 » \mathrm{LUMO}(36 \%) \\
\mathrm{H}-11 » \mathrm{LUMO}(23 \%)\end{array}$ \\
\hline 21 & 31174 & 320.8 & 0.000 & $\begin{array}{l}\text { H-19»LUMO (49\%) } \\
\text { H-14»LUMO (16\%) } \\
\text { H-11»LUMO (15\%) }\end{array}$ \\
\hline 22 & 31429 & 318.2 & 0.002 & $\begin{array}{l}\text { H-19»LUMO (41\%) } \\
\text { H-14»LUMO (33\%) } \\
\text { H-11»LUMO (12\%) }\end{array}$ \\
\hline 23 & 31528 & 317.2 & 0.010 & $H-2 » L+1(68 \%)$ \\
\hline 24 & 32510 & 307.6 & 0.004 & $\begin{array}{l}H-2 » L+2(53 \%) \\
\text { HOMO»L+2 (22\%) }\end{array}$ \\
\hline 25 & 32812 & 304.8 & 0.004 & $\begin{array}{l}H-3 » L+1(15 \%) \\
H-3 » L+2(70 \%)\end{array}$ \\
\hline 26 & 33021 & 302.8 & 0.005 & $\begin{array}{l}\mathrm{H}-18 » \mathrm{LUMO}(56 \%) \\
\mathrm{H}-4 » \mathrm{~L}+1(12 \%)\end{array}$ \\
\hline 27 & 33645 & 297.2 & 0.017 & $\begin{array}{l}\mathrm{H}-16 » \mathrm{LUMO}(49 \%) \\
\mathrm{H}-5 » \mathrm{~L}+2(23 \%)\end{array}$ \\
\hline 28 & 33787 & 296.0 & 0.003 & $\begin{array}{l}\mathrm{H}-16 » \mathrm{LUMO}(31 \%) \\
\mathrm{H}-5 » \mathrm{~L}+2(47 \%)\end{array}$ \\
\hline
\end{tabular}

\begin{tabular}{|c|c|c|c|c|}
\hline No. & $\begin{array}{l}\text { Energy } \\
\left(\mathrm{cm}^{-1}\right)\end{array}$ & $\begin{array}{c}\lambda \\
(\mathrm{nm})\end{array}$ & $f^{f^{a]}}$ & $\begin{array}{c}\text { Major } \\
\text { excitations }^{[b]}\end{array}$ \\
\hline 29 & 34509 & 289.8 & 0.245 & $\mathrm{H}-17 » \mathrm{LUMO}(55 \%)$ \\
\hline 30 & 34680 & 288.4 & 1.495 & $\begin{array}{l}\text { H-17»LUMO (18\%) } \\
\text { H-1»L+3 (18\%) } \\
\text { HOMO»L+4 (14\%) } \\
\text { HOMO»L+5 (19\%) }\end{array}$ \\
\hline 31 & 35190 & 284.2 & 0.039 & $\begin{array}{l}H-6 » L+1(12 \%) \\
H-6 » L+2(65 \%)\end{array}$ \\
\hline 32 & 35256 & 283.6 & 0.072 & $\begin{array}{l}\mathrm{H}-18 \gg \mathrm{LUMO}(11 \%) \\
\mathrm{H}-4 » \mathrm{~L}+1(54 \%) \\
\mathrm{H}-4 » \mathrm{~L}+2(11 \%)\end{array}$ \\
\hline 33 & 36390 & 274.8 & 0.004 & $\begin{array}{l}H-3 » L+1(73 \%) \\
H-3 » L+2(15 \%)\end{array}$ \\
\hline 34 & 36475 & 274.2 & 0.377 & $\mathrm{H}-22 » \mathrm{LUMO}(41 \%)$ \\
\hline 35 & 36784 & 271.9 & 0.079 & H-20»LUMO (78\%) \\
\hline 36 & 36899 & 271.0 & 0.069 & $\begin{array}{l}H-10 » L+2(22 \%) \\
H-8 » L+2(23 \%) \\
H-4 » L+2(10 \%)\end{array}$ \\
\hline 37 & 37077 & 269.7 & 0.008 & $\begin{array}{l}H-10 » L+2(10 \%) \\
H-4 » L+2(32 \%)\end{array}$ \\
\hline 38 & 37205 & 268.8 & 0.012 & $\begin{array}{l}H-12 » L+1(34 \%) \\
H-7 » L+1(22 \%)\end{array}$ \\
\hline 39 & 37400 & 267.4 & 0.003 & $\begin{array}{l}H-5 » L+1(71 \%) \\
H-5 » L+2(11 \%)\end{array}$ \\
\hline 40 & 37543 & 266.4 & 0.004 & $\begin{array}{l}\text { H-12»L+1 (14\%) } \\
\text { HOMO»L+4 (15\%) } \\
\text { HOMO»L+5 (11\%) }\end{array}$ \\
\hline 41 & 37628 & 265.8 & 0.024 & $\mathrm{H}-21 » \mathrm{LUMO}$ (69\%) \\
\hline 42 & 37682 & 265.4 & 0.000 & HOMO»L+11 (12\%) \\
\hline 43 & 37926 & 263.7 & 0.056 & $\begin{array}{l}\mathrm{H}-10 » \mathrm{~L}+2(14 \%) \\
\mathrm{H}-9 » \mathrm{~L}+2(21 \%) \\
\mathrm{H}-8 » \mathrm{~L}+2(28 \%)\end{array}$ \\
\hline 44 & 38050 & 262.8 & 0.222 & $\begin{array}{l}H-2 » L+3(17 \%) \\
H-1 » L+5(12 \%) \\
\text { HOMO»L+6 (16\%) }\end{array}$ \\
\hline 45 & 38118 & 262.3 & 0.016 & $\begin{array}{l}H-12 » L+1(13 \%) \\
H-7 » L+1(30 \%)\end{array}$ \\
\hline 46 & 38362 & 260.7 & 0.271 & $\begin{array}{l}\mathrm{H}-24 » \mathrm{LUMO}(13 \%) \\
\mathrm{H}-12 » \mathrm{~L}+1(16 \%) \\
\mathrm{H}-7 » \mathrm{~L}+1(14 \%)\end{array}$ \\
\hline 47 & 38680 & 258.5 & 0.145 & $\begin{array}{l}\mathrm{H}-24 » \mathrm{LUMO}(17 \%) \\
\mathrm{H}-14 » \mathrm{~L}+1(16 \%) \\
\mathrm{H}-11 » \mathrm{~L}+1(13 \%) \\
\mathrm{H}-6 » \mathrm{~L}+1(10 \%)\end{array}$ \\
\hline 48 & 38762 & 258.0 & 0.028 & $\begin{array}{l}H-6 » L+1(64 \%) \\
H-6 » L+2(13 \%)\end{array}$ \\
\hline 49 & 38989 & 256.5 & 0.097 & \\
\hline 50 & 39138 & 255.5 & 0.006 & $\begin{array}{l}H-15 » L+1(64 \%) \\
H-14 » L+1(11 \%)\end{array}$ \\
\hline
\end{tabular}

[a] Oscillator strength. [b] Contributions smaller than $10 \%$ are not included. $\mathrm{H}=\mathrm{HOMO}, \mathrm{L}=\mathrm{LUMO}$. Orbitals are numbered consecutively regardless of possible degeneracies. 
Table S7. Electronic transitions calculated for $\left[1 \supset \mathrm{PQ}^{2+}\right]$ using the TDA/PCM(acetone)/CAM-B3LYPGD3BJ/6-31G(d,p) level of theory.

\begin{tabular}{|c|c|c|c|c|}
\hline No. & $\begin{array}{l}\text { Energy } \\
\left(\mathrm{cm}^{-1}\right)\end{array}$ & $\begin{array}{c}\lambda \\
(\mathrm{nm})\end{array}$ & $f^{[a]}$ & $\begin{array}{c}\text { Major } \\
\text { excitations }^{[b]}\end{array}$ \\
\hline 1 & 13516 & 739.8 & 0.002 & HOMO»LUMO (94\%) \\
\hline 2 & 17550 & 569.8 & 0.000 & H-1»LUMO (93\%) \\
\hline \multirow[t]{2}{*}{3} & 19085 & 524.0 & 0.008 & H-2»LUMO (50\%) \\
\hline & & & & HOMO»L+1 (37\%) \\
\hline \multirow[t]{2}{*}{4} & 20635 & 484.6 & 0.002 & $\mathrm{H}-2 » \mathrm{LUMO}(42 \%)$ \\
\hline & & & & HOMO»L+1 (45\%) \\
\hline \multirow[t]{2}{*}{5} & 22062 & 453.3 & 0.002 & $\mathrm{H}-3 » L U M O(33 \%)$ \\
\hline & & & & $H-1 » L+1(55 \%)$ \\
\hline \multirow[t]{3}{*}{6} & 24165 & 413.8 & 0.007 & H-3»LUMO (29\%) \\
\hline & & & & $\mathrm{H}-2 » \mathrm{~L}+1$ (37\%) \\
\hline & & & & $\mathrm{H}-1 » \mathrm{~L}+1$ (17\%) \\
\hline \multirow[t]{3}{*}{7} & 24233 & 412.7 & 0.013 & H-5»LUMO (10\%) \\
\hline & & & & $\mathrm{H}-4 »$ LUMO (64\%) \\
\hline & & & & $H-4 » L+1(13 \%)$ \\
\hline \multirow[t]{2}{*}{8} & 24733 & 404.3 & 0.011 & H-5»LUMO (68\%) \\
\hline & & & & $H-5 » L+1(13 \%)$ \\
\hline \multirow[t]{3}{*}{9} & 25149 & 397.6 & 0.010 & $\mathrm{H}-3 » L U M O(27 \%)$ \\
\hline & & & & $H-2 » L+1(39 \%)$ \\
\hline & & & & $H-1 » L+1(15 \%)$ \\
\hline \multirow[t]{2}{*}{10} & 26383 & 379.0 & 0.001 & H-6»LUMO (79\%) \\
\hline & & & & $H-6 » L+1(15 \%)$ \\
\hline \multirow[t]{3}{*}{11} & 27750 & 360.4 & 0.008 & $\mathrm{H}-12 » \mathrm{LUMO}(46 \%)$ \\
\hline & & & & $\mathrm{H}-8 »$ LUMO (16\%) \\
\hline & & & & H-7»LUMO (28\%) \\
\hline \multirow[t]{3}{*}{12} & 27834 & 359.3 & 0.001 & H-15»LUMO (47\%) \\
\hline & & & & H-13»LUMO (12\%) \\
\hline & & & & H-10»LUMO (20\%) \\
\hline \multirow[t]{2}{*}{13} & 28118 & 355.6 & 0.020 & H-10»LUMO (49\%) \\
\hline & & & & $\mathrm{H}-10 » \mathrm{~L}+1(12 \%)$ \\
\hline \multirow[t]{3}{*}{14} & 28221 & 354.3 & 0.008 & H-9»LUMO (15\%) \\
\hline & & & & $\mathrm{H}-8 »$ LUMO (30\%) \\
\hline & & & & H-7»LUMO (27\%) \\
\hline 15 & 28575 & 350.0 & 0.001 & $\mathrm{H}-3 » \mathrm{~L}+1(47 \%)$ \\
\hline \multirow[t]{4}{*}{16} & 28643 & 349.1 & 0.007 & H-12»LUMO (10\%) \\
\hline & & & & H-9»LUMO (29\%) \\
\hline & & & & H-7»LUMO (19\%) \\
\hline & & & & $H-3 » L+1(14 \%)$ \\
\hline \multirow[t]{3}{*}{17} & 28989 & 345.0 & 0.004 & H-12»LUMO (11\%) \\
\hline & & & & H-11»LUMO (37\%) \\
\hline & & & & H-9»LUMO (14\%) \\
\hline 18 & 29331 & 340.9 & 0.015 & H-14»LUMO (55\%) \\
\hline & & & & H-11»LUMO (13\%) \\
\hline 19 & 29417 & 339.9 & 0.002 & $H-5 » L+1(11 \%)$ \\
\hline & & & & $\mathrm{H}-4 »$ LUMO (11\%) \\
\hline & & & & $H-4 » L+1(56 \%)$ \\
\hline 20 & 29932 & 334.1 & 0.025 & H-13»LUMO (15\%) \\
\hline & & & & $\mathrm{H}-5 » \mathrm{~L}+1(36 \%)$ \\
\hline 21 & 30069 & 332.6 & 0.039 & H-15»LUMO (12\%) \\
\hline & & & & H-13»LUMO (34\%) \\
\hline & & & & $H-13 » L+1(10 \%)$ \\
\hline & & & & $H-5 » L+1(16 \%)$ \\
\hline 22 & 30141 & 331.8 & 0.238 & HOMO»L+2 (27\%) \\
\hline & & & & HOMO»L+4 (30\%) \\
\hline 23 & 30189 & 331.2 & 0.003 & H-14»LUMO (13\%) \\
\hline & & & & H-11»LUMO (16\%) \\
\hline & & & & $\mathrm{H}-8 »$ LUMO (30\%) \\
\hline 24 & 30432 & 328.6 & 0.002 & H-19»LUMO (53\%) \\
\hline & & & & H-18»LUMO (25\%) \\
\hline 25 & 31083 & 321.7 & 0.172 & HOMO»L+2 (43\%) \\
\hline & & & & HOMO»L+4 (28\%) \\
\hline 26 & 31549 & 317.0 & 0.001 & H-6»LUMO (16\%) \\
\hline & & & & $\mathrm{H}-6 » \mathrm{~L}+1(73 \%)$ \\
\hline 27 & 32475 & 307.9 & 0.009 & $H-15 » L+1(11 \%)$ \\
\hline & & & & $H-11 » L+1(17 \%)$ \\
\hline
\end{tabular}

\begin{tabular}{|c|c|c|c|c|}
\hline No. & $\begin{array}{l}\text { Energy } \\
\left(\mathrm{cm}^{-1}\right)\end{array}$ & $\begin{array}{c}\lambda \\
(\mathrm{nm})\end{array}$ & $f^{[a]}$ & $\begin{array}{c}\text { Major } \\
\text { excitations }^{[b]}\end{array}$ \\
\hline \multirow[t]{2}{*}{28} & 32734 & 305.5 & 0.004 & $\mathrm{H}-15 » \mathrm{~L}+1(22 \%)$ \\
\hline & & & & $H-9 » L+1(18 \%)$ \\
\hline \multirow[t]{3}{*}{29} & 33065 & 302.4 & 0.019 & H-19»LUMO (15\%) \\
\hline & & & & H-18»LUMO (36\%) \\
\hline & & & & $\mathrm{H}-15 » \mathrm{~L}+1(16 \%)$ \\
\hline \multirow[t]{2}{*}{30} & 33446 & 299.0 & 0.021 & H-10»LUMO (14\%) \\
\hline & & & & $\mathrm{H}-10 » \mathrm{~L}+1$ (58\%) \\
\hline \multirow[t]{4}{*}{31} & 33646 & 297.2 & 0.003 & H-17»LUMO (17\%) \\
\hline & & & & H-16»LUMO (13\%) \\
\hline & & & & $\mathrm{H}-15 » \mathrm{~L}+1(14 \%)$ \\
\hline & & & & $H-9 » L+1(18 \%)$ \\
\hline \multirow[t]{3}{*}{32} & 33903 & 295.0 & 0.031 & $\mathrm{H}-11 » \mathrm{~L}+1$ (16\%) \\
\hline & & & & $H-9 » L+1$ (14\%) \\
\hline & & & & $H-1 » L+2(14 \%)$ \\
\hline 33 & 34181 & 292.6 & 0.151 & $H-1 » L+2(40 \%)$ \\
\hline \multirow[t]{2}{*}{34} & 34347 & 291.2 & 0.004 & H-17»LUMO (25\%) \\
\hline & & & & H-16»LUMO (49\%) \\
\hline \multirow[t]{2}{*}{35} & 34603 & 289.0 & 0.008 & $\mathrm{H}-12 » \mathrm{~L}+1(40 \%)$ \\
\hline & & & & $\mathrm{H}-7 » \mathrm{~L}+1(32 \%)$ \\
\hline 36 & 34863 & 286.8 & 0.010 & H-24»LUMO (59\%) \\
\hline 37 & 34953 & 286.1 & 0.015 & HOMO»L+3 (60\%) \\
\hline \multirow[t]{4}{*}{38} & 35073 & 285.1 & 0.016 & H-22»LUMO (20\%) \\
\hline & & & & $\mathrm{H}-15 » \mathrm{~L}+1(10 \%)$ \\
\hline & & & & $\mathrm{H}-13 » \mathrm{~L}+1$ (17\%) \\
\hline & & & & $H-7 » L+1(14 \%)$ \\
\hline \multirow[t]{3}{*}{39} & 35356 & 282.8 & 0.112 & $\mathrm{H}-13 » \mathrm{~L}+1$ (17\%) \\
\hline & & & & $\mathrm{H}-12 » \mathrm{~L}+1(13 \%)$ \\
\hline & & & & $H-7 » L+1(23 \%)$ \\
\hline \multirow[t]{3}{*}{40} & 35413 & 282.4 & 0.205 & $\mathrm{H}-22 » \mathrm{LUMO}(16 \%)$ \\
\hline & & & & $H-7 » L+1(14 \%)$ \\
\hline & & & & HOMO»L+5 (10\%) \\
\hline \multirow[t]{2}{*}{41} & 35845 & 279.0 & 1.340 & H-22»LUMO (17\%) \\
\hline & & & & HOMO»L+5 (27\%) \\
\hline \multirow[t]{2}{*}{42} & 36121 & 276.8 & 0.028 & $\mathrm{H}-14 » \mathrm{~L}+1(41 \%)$ \\
\hline & & & & $H-8 » L+1(14 \%)$ \\
\hline \multirow[t]{3}{*}{43} & 36510 & 273.9 & 0.021 & $\mathrm{H}-19 » \mathrm{~L}+1(47 \%)$ \\
\hline & & & & $\mathrm{H}-18 » \mathrm{~L}+1$ (13\%) \\
\hline & & & & $H-2 » L+2(16 \%)$ \\
\hline \multirow[t]{4}{*}{44} & 36602 & 273.2 & 0.013 & $\mathrm{H}-19 » \mathrm{~L}+1(14 \%)$ \\
\hline & & & & $\mathrm{H}-18 » \mathrm{~L}+1$ (10\%) \\
\hline & & & & $\mathrm{H}-8 » \mathrm{~L}+1(22 \%)$ \\
\hline & & & & $\mathrm{H}-2 » \mathrm{~L}+2(21 \%)$ \\
\hline \multirow[t]{2}{*}{45} & 36754 & 272.1 & 0.016 & H-20»LUMO (82\%) \\
\hline & & & & $H-20 » L+1(10 \%)$ \\
\hline \multirow[t]{3}{*}{46} & 37090 & 269.6 & 0.036 & $\mathrm{H}-14 » \mathrm{~L}+1(29 \%)$ \\
\hline & & & & $\mathrm{H}-11 » \mathrm{~L}+1$ (14\%) \\
\hline & & & & $\mathrm{H}-8 » \mathrm{~L}+1(15 \%)$ \\
\hline \multirow[t]{2}{*}{47} & 37283 & 268.2 & 0.015 & H-25»LUMO (30\%) \\
\hline & & & & H-22»LUMO (13\%) \\
\hline \multirow[t]{4}{*}{48} & 37499 & 266.7 & 0.021 & H-21»LUMO (10\%) \\
\hline & & & & $\mathrm{H}-19 » \mathrm{~L}+1$ (16\%) \\
\hline & & & & $\mathrm{H}-18 » \mathrm{~L}+1(29 \%)$ \\
\hline & & & & $H-3 » L+2(10 \%)$ \\
\hline 49 & 37612 & 265.9 & 0.340 & $H-7 » L+4(11 \%)$ \\
\hline & & & & HOMO»L+12 (11\%) \\
\hline 50 & 37689 & 265.3 & 0.008 & H-21»LUMO (61\%) \\
\hline & & & & $H-21 » L+1(10 \%)$ \\
\hline
\end{tabular}

[a] Oscillator strength. [b] Contributions smaller than $10 \%$ are not included. $\mathrm{H}=\mathrm{HOMO}, \mathrm{L}=$ LUMO. Orbitals are numbered consecutively regardless of possible degeneracies. 
Table S8. Electronic transitions calculated for [1 $\supset A Q]$ using the TDA/PCM(acetone)/CAM-B3LYPGD3BJ/6-31G(d,p) level of theory.

\begin{tabular}{|c|c|c|c|c|}
\hline No. & $\begin{array}{l}\text { Energy } \\
\left(\mathrm{cm}^{-1}\right)\end{array}$ & $\begin{array}{c}\lambda \\
(\mathrm{nm})\end{array}$ & $f^{[a]}$ & $\begin{array}{c}\text { Major } \\
\text { excitations }^{[b]}\end{array}$ \\
\hline 1 & 27446 & 364.3 & 0.000 & $\mathrm{H}-15 » L U M O(76 \%)$ \\
\hline 2 & 29206 & 342.4 & 0.023 & $\begin{array}{l}\text { HOMO»LUMO } \\
(82 \%)\end{array}$ \\
\hline 3 & 29543 & 338.5 & 0.001 & $\begin{array}{l}\text { H-23»LUMO (17\%) } \\
\text { H-22»LUMO (60\%) } \\
\text { H-15»L+3 (10\%) }\end{array}$ \\
\hline 4 & 30500 & 327.9 & 0.382 & HOMO»L+1 (76\%) \\
\hline 5 & 31161 & 320.9 & 0.020 & H-1»LUMO (94\%) \\
\hline 6 & 32168 & 310.9 & 0.004 & $\begin{array}{l}\text { H-7»LUMO (20\%) } \\
\text { H-2»LUMO (47\%) }\end{array}$ \\
\hline 7 & 34476 & 290.1 & 0.004 & $\begin{array}{l}\text { H-8»LUMO (29\%) } \\
\text { H-7»LUMO (18\%) } \\
\text { H-4»LUMO (13\%) }\end{array}$ \\
\hline 8 & 35642 & 280.6 & 0.958 & $\begin{array}{l}\text { H-7»LUMO (12\%) } \\
\text { H-2»LUMO (13\%) } \\
\text { H-1»L+1 (14\%) } \\
\text { HOMO»L+2 (21\%) }\end{array}$ \\
\hline 9 & 35941 & 278.2 & 0.485 & $\begin{array}{l}\text { H-8»LUMO (22\%) } \\
\text { H-2»LUMO (23\%) }\end{array}$ \\
\hline 10 & 36555 & 273.6 & 0.066 & H-11»LUMO (39\%) \\
\hline 11 & 37046 & 269.9 & 0.880 & $\begin{array}{l}\text { H-1»L+1 (16\%) } \\
\text { HOMO»L+5 (21\%) }\end{array}$ \\
\hline 12 & 38076 & 262.6 & 0.198 & $\begin{array}{l}\mathrm{H}-2 » \mathrm{~L}+1(19 \%) \\
\mathrm{H}-1 » \mathrm{~L}+2(23 \%) \\
\text { HOMO»L+4 (17\%) }\end{array}$ \\
\hline 13 & 38615 & 259.0 & 0.007 & H-5»LUMO (41\%) \\
\hline 14 & 39135 & 255.5 & 0.079 & $\begin{array}{l}\text { H-5»LUMO (10\%) } \\
\text { HOMO»L+3 (24\%) }\end{array}$ \\
\hline 15 & 39164 & 255.3 & 0.002 & H-3»LUMO (52\%) \\
\hline 16 & 39505 & 253.1 & 0.011 & $\begin{array}{l}\text { H-12»LUMO (25\%) } \\
\text { H-4»LUMO (12\%) } \\
\text { H-3»LUMO (20\%) }\end{array}$ \\
\hline 17 & 39591 & 252.6 & 0.016 & $\begin{array}{l}\text { H-4»LUMO (30\%) } \\
\text { H-3»LUMO (15\%) }\end{array}$ \\
\hline 18 & 39701 & 251.9 & 0.057 & $\begin{array}{l}\text { H-12»LUMO (15\%) } \\
\text { H-4»LUMO (32\%) }\end{array}$ \\
\hline 19 & 39944 & 250.4 & 0.005 & H-5»LUMO (11\%) \\
\hline 20 & 40096 & 249.4 & 0.021 & \\
\hline 21 & 40432 & 247.3 & 0.075 & HOMO»L+3 (25\%) \\
\hline 22 & 40509 & 246.9 & 0.011 & $\begin{array}{l}\text { H-1»L+1 (20\%) } \\
\text { HOMO»L+2 (23\%) }\end{array}$ \\
\hline 23 & 40738 & 245.5 & 0.003 & HOMO»L+17 (12\%) \\
\hline 24 & 40901 & 244.5 & 0.007 & $\begin{array}{l}\text { H-14»LUMO (11\%) } \\
\text { HOMO»L+3 (11\%) }\end{array}$ \\
\hline 25 & 41135 & 243.1 & 0.005 & \\
\hline 26 & 41510 & 240.9 & 0.003 & \\
\hline 27 & 41651 & 240.1 & 0.005 & H-6»LUMO (65\%) \\
\hline 28 & 42031 & 237.9 & 0.008 & $\begin{array}{l}\mathrm{H}-2 » \mathrm{~L}+2(25 \%) \\
\mathrm{H}-1 » \mathrm{~L}+4(10 \%)\end{array}$ \\
\hline
\end{tabular}

\begin{tabular}{|c|c|c|c|c|}
\hline No. & $\begin{array}{l}\text { Energy } \\
\left(\mathrm{cm}^{-1}\right)\end{array}$ & $\begin{array}{c}\lambda \\
(\mathrm{nm})\end{array}$ & $f^{\text {fa] }}$ & $\begin{array}{c}\text { Major } \\
\text { excitations }^{[b]}\end{array}$ \\
\hline 29 & 42159 & 237.2 & 0.036 & $\begin{array}{l}\mathrm{H}-13 » \mathrm{LUMO}(36 \%) \\
\mathrm{H}-1 » \mathrm{~L}+3(13 \%)\end{array}$ \\
\hline 30 & 42436 & 235.7 & 0.034 & $\mathrm{H}-1 » \mathrm{~L}+3(40 \%)$ \\
\hline 31 & 42786 & 233.7 & 0.021 & $H-3 » L+6(20 \%)$ \\
\hline 32 & 43180 & 231.6 & 0.179 & $\begin{array}{l}\mathrm{H}-2 » \mathrm{~L}+1(24 \%) \\
\mathrm{H}-2 » \mathrm{~L}+3(15 \%)\end{array}$ \\
\hline 33 & 43212 & 231.4 & 0.203 & $\begin{array}{l}H-2 » L+1(23 \%) \\
H-2 » L+3(17 \%)\end{array}$ \\
\hline 34 & 43492 & 229.9 & 0.061 & H-9»LUMO (38\%) \\
\hline 35 & 43560 & 229.6 & 0.108 & $\begin{array}{l}\text { H-19»LUMO (24\%) } \\
\text { H-18»LUMO (18\%) } \\
\text { H-11»LUMO (10\%) } \\
\text { H-2»L+3 (10\%) }\end{array}$ \\
\hline 36 & 43772 & 228.5 & 0.008 & H-9»LUMO (21\%) \\
\hline 37 & 43941 & 227.6 & 0.017 & $\begin{array}{l}\text { H-20»LUMO (26\%) } \\
\text { H-16»LUMO (24\%) } \\
\text { H-11»LUMO (10\%) }\end{array}$ \\
\hline 38 & 44104 & 226.7 & 0.023 & $\begin{array}{l}\text { H-17» LUMO (30\%) } \\
\text { H-10»LUMO (33\%) }\end{array}$ \\
\hline 39 & 44335 & 225.6 & 0.005 & $\begin{array}{l}\text { H-17»LUMO (14\%) } \\
\text { H-13»LUMO (12\%) } \\
\text { H-10»LUMO (45\%) }\end{array}$ \\
\hline 40 & 44938 & 222.5 & 0.004 & $\mathrm{H}-2 » \mathrm{~L}+4(22 \%)$ \\
\hline 41 & 45185 & 221.3 & 0.014 & $\begin{array}{l}\mathrm{H}-1 » \mathrm{~L}+2(27 \%) \\
\text { HOMO»L+4 (41\%) }\end{array}$ \\
\hline 42 & 45668 & 219.0 & 0.004 & $\begin{array}{l}\mathrm{H}-5 » \mathrm{~L}+1(30 \%) \\
\mathrm{H}-1 » \mathrm{~L}+1(13 \%) \\
\text { HOMO»L+5 (11\%) }\end{array}$ \\
\hline 43 & 45716 & 218.7 & 0.003 & $\begin{array}{l}\mathrm{H}-22 » \mathrm{LUMO}(11 \%) \\
\mathrm{H}-15 » \mathrm{~L}+3(57 \%)\end{array}$ \\
\hline 44 & 45784 & 218.4 & 0.080 & $\begin{array}{l}\mathrm{H}-19 » \mathrm{LUMO}(14 \%) \\
\mathrm{H}-14 » \mathrm{LUMO}(27 \%)\end{array}$ \\
\hline 45 & 46230 & 216.3 & 0.170 & $\begin{array}{l}H-16 » L+1(16 \%) \\
H-11 » L+1(13 \%)\end{array}$ \\
\hline 46 & 46456 & 215.3 & 0.152 & $\begin{array}{l}H-7 » L+3(17 \%) \\
H-4 » L+3(10 \%) \\
H-2 » L+2(10 \%)\end{array}$ \\
\hline 47 & 46542 & 214.9 & 0.072 & $\begin{array}{l}\mathrm{H}-2 » \mathrm{~L}+2(21 \%) \\
\mathrm{H}-1 » \mathrm{~L}+4(26 \%)\end{array}$ \\
\hline 48 & 46668 & 214.3 & 0.046 & H-16»LUMO (10\%) \\
\hline 49 & 46847 & 213.5 & 0.013 & $\begin{array}{l}\text { H-20»LUMO (10\%) } \\
\text { H-16»LUMO (17\%) }\end{array}$ \\
\hline 50 & 46979 & 212.9 & 0.018 & \\
\hline
\end{tabular}

[a] Oscillator strength. [b] Contributions smaller than $10 \%$ are not included. $\mathrm{H}=$ HOMO, $\mathrm{L}=$ LUMO. Orbitals are numbered consecutively regardless of possible degeneracies. 
Table 59. Electronic transitions calculated for 1 using the TDA/PCM(acetone)/CAM-B3LYP-GD3BJ/6$31 \mathrm{G}(\mathrm{d}, \mathrm{p})$ level of theory.

\begin{tabular}{|c|c|c|c|c|}
\hline No. & $\begin{array}{l}\text { Energy } \\
\left(\mathrm{cm}^{-1}\right)\end{array}$ & $\begin{array}{c}\lambda \\
(\mathrm{nm})\end{array}$ & $f^{[\mathrm{al}]}$ & $\begin{array}{c}\text { Major } \\
\text { excitations }^{[b]}\end{array}$ \\
\hline 1 & 31257 & 319.9 & 0.437 & $\begin{array}{l}\text { HOMO»LUMO } \\
(80 \%)\end{array}$ \\
\hline 2 & 36320 & 275.3 & 2.490 & $\begin{array}{l}\text { H-1»LUMO (30\%) } \\
\text { HOMO»L+1 (40\%) }\end{array}$ \\
\hline 3 & 37953 & 263.5 & 0.453 & $\begin{array}{l}\text { H-13»LUMO (13\%) } \\
\text { H-1»LUMO (11\%) } \\
\text { HOMO»L+3 (32\%) }\end{array}$ \\
\hline 4 & 38566 & 259.3 & 0.210 & $\begin{array}{l}\text { H-2»LUMO (12\%) } \\
\text { H-1»L+1 (18\%) } \\
\text { HOMO»L+2 (18\%) } \\
\text { HOMO»L+6 (13\%) }\end{array}$ \\
\hline 5 & 39914 & 250.5 & 0.219 & $\begin{array}{l}\text { H-2»LUMO (16\%) } \\
\text { H-1»L+1 (14\%) } \\
\text { HOMO»L+6 (17\%) }\end{array}$ \\
\hline 6 & 40288 & 248.2 & 0.023 & $\begin{array}{l}\text { H-15»LUMO (15\%) } \\
\text { HOMO»L+9 (10\%) }\end{array}$ \\
\hline 7 & 40447 & 247.2 & 0.002 & $\begin{array}{l}H-2 » L+4(15 \%) \\
H-1 » L+7(17 \%)\end{array}$ \\
\hline 8 & 40471 & 247.1 & 0.001 & $\begin{array}{l}\mathrm{H}-2 » \mathrm{~L}+7(11 \%) \\
\mathrm{H}-1 » \mathrm{~L}+4(14 \%)\end{array}$ \\
\hline 9 & 40839 & 244.9 & 0.001 & $\begin{array}{l}\text { H-16»LUMO (19\%) } \\
\text { HOMO»L+13 (19\%) }\end{array}$ \\
\hline 10 & 41205 & 242.7 & 0.024 & $\begin{array}{l}\text { H-1»LUMO (31\%) } \\
\text { HOMO»L+1 (39\%) }\end{array}$ \\
\hline 11 & 41431 & 241.4 & 0.003 & $\mathrm{H}-11 » \mathrm{~L}+1$ (11\%) \\
\hline 12 & 41446 & 241.3 & 0.003 & $H-12 » L+1(11 \%)$ \\
\hline 13 & 42798 & 233.7 & 0.101 & $\begin{array}{l}\text { H-6»LUMO (12\%) } \\
\text { H-2»L+1 (24\%) } \\
\text { H-1»L+2 (19\%) }\end{array}$ \\
\hline 14 & 42991 & 232.6 & 0.016 & $\mathrm{H}-3 » \mathrm{~L}+4(18 \%)$ \\
\hline 15 & 43506 & 229.9 & 0.015 & \\
\hline 16 & 44179 & 226.4 & 0.005 & $\begin{array}{l}\text { H-2»LUMO (42\%) } \\
\text { HOMO»L+2 (27\%) }\end{array}$ \\
\hline 17 & 45646 & 219.1 & 0.004 & $\begin{array}{l}H-6 » L+1(11 \%) \\
H-2 » L+2(21 \%)\end{array}$ \\
\hline 18 & 45870 & 218.0 & 0.024 & $\begin{array}{l}\text { H-1»L+1 (41\%) } \\
\text { HOMO»LUMO } \\
(12 \%) \\
\text { HOMO»L+2 (28\%) }\end{array}$ \\
\hline 19 & 46388 & 215.6 & 0.031 & $\begin{array}{l}\text { H-6»LUMO (20\%) } \\
\text { H-5»LUMO (16\%) } \\
\text { HOMO»L+3 (12\%) } \\
\text { HOMO»L+5 (11\%) }\end{array}$ \\
\hline 20 & 47352 & 211.2 & 0.056 & $\mathrm{H}-4 »$ L+4 (24\%) \\
\hline 21 & 47499 & 210.5 & 0.024 & $\begin{array}{l}\text { H-13»LUMO (44\%) } \\
\text { HOMO»L+3 (14\%) } \\
\text { HOMO»L+5 (14\%) }\end{array}$ \\
\hline 22 & 47589 & 210.1 & 0.024 & $\begin{array}{l}\mathrm{H}-4 » \mathrm{LUMO}(21 \%) \\
\mathrm{H}-4 » \mathrm{~L}+2(12 \%) \\
\mathrm{H}-1 » \mathrm{~L}+4(13 \%)\end{array}$ \\
\hline
\end{tabular}

\begin{tabular}{|c|c|c|c|c|}
\hline No. & $\begin{array}{l}\text { Energy } \\
\left(\mathrm{cm}^{-1}\right)\end{array}$ & $\begin{array}{c}\lambda \\
(\mathrm{nm})\end{array}$ & $f^{\text {fa] }}$ & $\begin{array}{c}\text { Major } \\
\text { excitations }^{[b]}\end{array}$ \\
\hline 23 & 47816 & 209.1 & 0.007 & $\begin{array}{l}\mathrm{H}-2 » \mathrm{~L}+1(39 \%) \\
\mathrm{H}-1 » \mathrm{~L}+2(24 \%)\end{array}$ \\
\hline 24 & 47950 & 208.6 & 0.109 & $\begin{array}{l}\mathrm{H}-3 » \operatorname{LUMO}(27 \%) \\
\mathrm{H}-3 » \mathrm{~L}+2(13 \%)\end{array}$ \\
\hline 25 & 48913 & 204.4 & 0.044 & $\begin{array}{l}\text { H-14»LUMO (17\%) } \\
\text { H-10»LUMO (18\%) } \\
\text { HOMO»L+6 (27\%) }\end{array}$ \\
\hline 26 & 49029 & 204.0 & 0.134 & $H-6 » L+2(11 \%)$ \\
\hline 27 & 49315 & 202.8 & 0.061 & H-3»LUMO (10\%) \\
\hline 28 & 49492 & 202.1 & 0.068 & H-3»LUMO (27\%) \\
\hline 29 & 49648 & 201.4 & 0.095 & H-6»LUMO (10\%) \\
\hline 30 & 49693 & 201.2 & 0.152 & H-14»LUMO (11\%) \\
\hline 31 & 49871 & 200.5 & 0.072 & $H-1 » L+3(38 \%)$ \\
\hline 32 & 49907 & 200.4 & 0.013 & \\
\hline 33 & 50026 & 199.9 & 0.005 & $\begin{array}{l}\mathrm{H}-4 » \mathrm{LUMMO}(25 \%) \\
\mathrm{H}-3 » \mathrm{~L}+1(32 \%)\end{array}$ \\
\hline 34 & 50067 & 199.7 & 0.020 & $\begin{array}{l}\text { H-6»LUMO (10\%) } \\
\text { H-5»LUMO (22\%) }\end{array}$ \\
\hline 35 & 50400 & 198.4 & 0.005 & $\begin{array}{l}\text { H-15»LUMO (29\%) } \\
\text { HOMO»L+9 (15\%) }\end{array}$ \\
\hline 36 & 50762 & 197.0 & 0.002 & $\begin{array}{l}\mathrm{H}-5 » \mathrm{~L}+1(10 \%) \\
\mathrm{H}-4 » \mathrm{LUMO}(18 \%)\end{array}$ \\
\hline 37 & 51000 & 196.1 & 0.008 & $\begin{array}{l}H-5 » L+1(15 \%) \\
H-2 » L+2(16 \%) \\
H-1 » L+5(22 \%)\end{array}$ \\
\hline 38 & 51088 & 195.7 & 0.000 & \\
\hline 39 & 51204 & 195.3 & 0.003 & \\
\hline 40 & 51260 & 195.1 & 0.110 & $\begin{array}{l}\text { H-12»LUMO (10\%) } \\
\text { H-4»L+1 (12\%) } \\
\text { HOMO»L+8 (14\%) }\end{array}$ \\
\hline 41 & 51321 & 194.9 & 0.001 & $\begin{array}{l}H-6 » L+1(11 \%) \\
H-5 » L+1(12 \%)\end{array}$ \\
\hline 42 & 51432 & 194.4 & 0.003 & \\
\hline 43 & 51523 & 194.1 & 0.022 & $\begin{array}{l}H-4 » L+1(18 \%) \\
\text { HOMO»L+4 (15\%) }\end{array}$ \\
\hline 44 & 51613 & 193.8 & 0.047 & $\begin{array}{l}H-2 » L+5(13 \%) \\
H-1 » L+6(15 \%)\end{array}$ \\
\hline 45 & 51729 & 193.3 & 0.052 & \\
\hline 46 & 51875 & 192.8 & 0.008 & \\
\hline 47 & 51969 & 192.4 & 0.017 & \\
\hline 48 & 52026 & 192.2 & 0.225 & $\begin{array}{l}\text { H-16»LUMO (14\%) } \\
\text { HOMO»L+13 (21\%) }\end{array}$ \\
\hline 49 & 52181 & 191.6 & 0.049 & H-7»LUMO (12\%) \\
\hline 50 & 52336 & 191.1 & 0.047 & \\
\hline
\end{tabular}

[a] Oscillator strength. [b] Contributions smaller than $10 \%$ are not included. $\mathrm{H}=\mathrm{HOMO}, \mathrm{L}=$ LUMO. Orbitals are numbered consecutively regardless of possible degeneracies. 
Table S10. Crystal data and structure refinement for $5 \cdot \mathrm{C}_{6} \mathrm{H}_{14} \cdot \mathrm{H}_{2} \mathrm{O}$.

Identification code

Empirical formula

Formula weight

Temperature

Wavelength

Crystal system

Space group

Unit cell dimensions

Volume

$\mathrm{Z}$

Density (calculated)

Absorption coefficient

$\mathrm{F}(000)$

Crystal size

Theta range for data collection

Index ranges

Reflections collected

Independent reflections

Completeness to theta $=67.000^{\circ}$

Absorption correction

Max. and min. transmission

Refinement method

Data / restraints / parameters

Goodness-of-fit on $\mathrm{F}^{2}$

Final $\mathrm{R}$ indices [I $>2 \operatorname{sigma}(\mathrm{I})]$

$\mathrm{R}$ indices (all data)

Extinction coefficient

Largest diff. peak and hole
RF07A

C90 H104.40 O8.20

1317.33

100(2) K

1.54184 Ĺ

Triclinic

P-1

$\mathrm{a}=12.027(2) \AA$

$\alpha=72.10(5)^{\circ}$.

$\mathrm{b}=16.806(3) \AA$ $\beta=84.41(4)^{\circ}$.

$\mathrm{c}=19.642(4) \AA$ $\gamma=85.99(4)^{\circ}$.

3756.7(16) $\AA^{3}$

2

$1.165 \mathrm{Mg} / \mathrm{m}^{3}$

$0.567 \mathrm{~mm}^{-1}$

1420

$0.650 \times 0.110 \times 0.070 \mathrm{~mm}^{3}$

2.371 to $67.997^{\circ}$.

$-13<=\mathrm{h}<=14,-20<=\mathrm{k}<=17,-23<=\mathrm{l}<=23$

29270

$13674[\mathrm{R}(\mathrm{int})=0.0695]$

$99.9 \%$

Analytical

0.968 and 0.822

Full-matrix least-squares on $\mathrm{F}^{2}$

13674 / 0 / 896

1.040

$\mathrm{R} 1=0.0775, \mathrm{wR} 2=0.2021$

$\mathrm{R} 1=0.1039, \mathrm{wR} 2=0.2405$

$\mathrm{n} / \mathrm{a}$

0.428 and -0.460 e. $\AA^{-3}$ 
Table S11. Crystal data and structure refinement for $1 \cdot 3 \mathrm{C}_{6} \mathrm{H}_{6}$.

Identification code

Empirical formula

Formula weight

Temperature

Wavelength

Crystal system

Space group

Unit cell dimensions

Volume

Z

Density (calculated)

Absorption coefficient

$\mathrm{F}(000)$

Crystal size

Theta range for data collection

Index ranges

Reflections collected

Independent reflections

Completeness to theta $=67.000^{\circ}$

Absorption correction

Max. and min. transmission

Refinement method

Data / restraints / parameters

Goodness-of-fit on $\mathrm{F}^{2}$

Final $\mathrm{R}$ indices [I $>2 \operatorname{sigma}(\mathrm{I})]$

$\mathrm{R}$ indices (all data)

Absolute structure parameter

Extinction coefficient

Largest diff. peak and hole rf05a

C98 H96 O4

1337.74

100(2) K

$1.54184 \AA$

Orthorhombic

Pca21

$\mathrm{a}=32.979(5) \AA$

$\alpha=90^{\circ}$.

$\mathrm{b}=18.110(3) \AA$

$\beta=90^{\circ}$.

$\mathrm{c}=25.513(5) \AA$

$\gamma=90^{\circ}$.

8

$1.166 \mathrm{Mg} / \mathrm{m}^{3}$

$0.530 \mathrm{~mm}^{-1}$

5728

$0.340 \times 0.150 \times 0.080 \mathrm{~mm}^{3}$

3.625 to $67.158^{\circ}$.

$-38<=\mathrm{h}<=31,-17<=\mathrm{k}<=20,-21<=1<=29$

63836

20179 [R(int) $=0.0372]$

$97.3 \%$

Analytical

0.965 and 0.910

Full-matrix least-squares on $\mathrm{F}^{2}$

20179 / $16 / 1750$

1.090

$\mathrm{R} 1=0.0827, \mathrm{wR} 2=0.2146$

$\mathrm{R} 1=0.1053, \mathrm{wR} 2=0.2355$

$-0.19(16)$

$\mathrm{n} / \mathrm{a}$

0.533 and -0.446 e. $\AA^{-3}$ 
Table S12. Crystal data and structure refinement for $1 \cdot 3.2 \mathrm{CH}_{2} \mathrm{Cl}_{2}$.

Identification code

Empirical formula

Formula weight

Temperature

Wavelength

Crystal system

Space group

Unit cell dimensions

Volume

Z

Density (calculated)

Absorption coefficient

$\mathrm{F}(000)$

Crystal size

Theta range for data collection

Index ranges

Reflections collected

Independent reflections

Completeness to theta $=67.000^{\circ}$

Absorption correction

Max. and min. transmission

Refinement method

Data / restraints / parameters

Goodness-of-fit on $\mathrm{F}^{2}$

Final $\mathrm{R}$ indices [I $>2 \operatorname{sigma}(\mathrm{I})]$

$\mathrm{R}$ indices (all data)

Extinction coefficient

Largest diff. peak and hole rf07abs

C83.20 H84.40 Cl6.40 O4

1375.18

100(2) K

$1.5418 \AA$

Monoclinic

$\mathrm{P} 21 / \mathrm{n}$

$\mathrm{a}=16.394(7) \AA$

$\alpha=90.00(3)^{\circ}$.

$\mathrm{b}=24.705(10) \AA$

$\beta=92.58(4)^{\circ}$.

$\mathrm{c}=18.366(7) \AA$

$\gamma=90.00(3)^{\circ}$.

7431(5) $\AA^{3}$

4

$1.229 \mathrm{Mg} / \mathrm{m}^{3}$

$2.621 \mathrm{~mm}^{-1}$

2898

$0.550 \times 0.310 \times 0.170 \mathrm{~mm}^{3}$

3.000 to $75.613^{\circ}$.

$-18<=\mathrm{h}<=20,-30<=\mathrm{k}<=26,-22<=1<=21$

37405

$14977[\mathrm{R}(\mathrm{int})=0.0624]$

$100.0 \%$

Analytical

0.680 and 0.289

Full-matrix least-squares on $\mathrm{F}^{2}$

14977 / 16 / 936

1.667

$\mathrm{R} 1=0.1029, \mathrm{wR} 2=0.2682$

$\mathrm{R} 1=0.1207, \mathrm{wR} 2=0.2891$

$\mathrm{n} / \mathrm{a}$

1.102 and -0.705 e. $\AA^{-3}$ 
Table S13. Crystal data and structure refinement for $\left[1 \mathrm{DDQ}^{2+}\right]\left[\mathrm{PF}_{6}{ }^{-}\right]_{2} \cdot \mathrm{C}_{3} \mathrm{H}_{6} \mathrm{O}$.

Identification code

Empirical formula

Formula weight

Temperature

Wavelength

Crystal system

Space group

Unit cell dimensions

Volume

Z

Density (calculated)

Absorption coefficient

$\mathrm{F}(000)$

Crystal size

Theta range for data collection

Index ranges

Reflections collected

Independent reflections

Completeness to theta $=25.500^{\circ}$

Absorption correction

Refinement method

Data / restraints / parameters

Goodness-of-fit on $\mathrm{F}^{2}$

Final R indices [I > 2sigma(I)]

$\mathrm{R}$ indices (all data)

Extinction coefficient

Largest diff. peak and hole stepien

C95 H96 F12 N2 O5 P2

1635.67

100(2) K

$0.71073 \AA$

Monoclinic

$\mathrm{P} 21 / \mathrm{c}$

$\mathrm{a}=23.011(10) \AA \quad \alpha=90^{\circ}$.

$\mathrm{b}=16.617(9) \AA \quad \beta=91.04(3)^{\circ}$.

$\mathrm{c}=21.113(9) \AA \quad \gamma=90^{\circ}$.

8072(7) $\AA^{3}$

4

$1.346 \mathrm{Mg} / \mathrm{m}^{3}$

$0.138 \mathrm{~mm}^{-1}$

3432

$0.380 \times 0.280 \times 0.120 \mathrm{~mm}^{3}$

3.234 to $28.977^{\circ}$.

$-30<=\mathrm{h}<=30,-21<=\mathrm{k}<=13,-28<=\mathrm{l}<=28$

30480

$30480[$ R(int $)=$ ?]

$95.8 \%$

None

Full-matrix least-squares on $\mathrm{F}^{2}$

30480 / 8 / 1001

1.004

$\mathrm{R} 1=0.0732, \mathrm{wR} 2=0.1862$

$\mathrm{R} 1=0.1622, \mathrm{wR} 2=0.2059$

$\mathrm{n} / \mathrm{a}$

0.680 and -0.511 e. $\AA^{-3}$ 
Table S14. Crystal data and structure refinement for $\left[1 \mathrm{DPQ}^{2+}\right]\left[\mathrm{PF}_{6}{ }^{-}\right]_{2} \cdot \mathrm{C}_{3} \mathrm{H}_{6} \mathrm{O}$.

Identification code

Empirical formula

Formula weight

Temperature

Wavelength

Crystal system

Space group

Unit cell dimensions

Volume

Z

Density (calculated)

Absorption coefficient

$\mathrm{F}(000)$

Crystal size

Theta range for data collection

Index ranges

Reflections collected

Independent reflections

Completeness to theta $=67.000^{\circ}$

Absorption correction

Max. and min. transmission

Refinement method

Data / restraints / parameters

Goodness-of-fit on $\mathrm{F}^{2}$

Final $\mathrm{R}$ indices [I $>2 \operatorname{sigma}(\mathrm{I})]$

$\mathrm{R}$ indices (all data)

Extinction coefficient

Largest diff. peak and hole rf21a

C97 H96 F12 N2 O5 P2

1659.69

100(2) K

$1.54184 \AA$

Monoclinic

$\mathrm{P} 21 / \mathrm{c}$

$\mathrm{a}=21.800(9) \AA$

$\alpha=90^{\circ}$.

$\mathrm{b}=18.632(8) \AA$

$\beta=102.05(5)^{\circ}$.

$\mathrm{c}=20.532(8) \AA$

$\gamma=90^{\circ}$.

8156(6) $\AA^{3}$

4

$1.352 \mathrm{Mg} / \mathrm{m}^{3}$

$1.196 \mathrm{~mm}^{-1}$

3480

$0.280 \times 0.180 \times 0.013 \mathrm{~mm}^{3}$

3.587 to $69.093^{\circ}$.

$-26<=\mathrm{h}<=26,-22<=\mathrm{k}<=22,-15<=\mathrm{l}<=24$

22988

22988 [R(int) $=$ ?]

$99.9 \%$

Analytical

0.985 and 0.800

Full-matrix least-squares on $\mathrm{F}^{2}$

22988 / 1 / 966

0.875

$\mathrm{R} 1=0.1082, \mathrm{wR} 2=0.1297$

$\mathrm{R} 1=0.3169, \mathrm{wR} 2=0.1680$

$\mathrm{n} / \mathrm{a}$

0.498 and -0.545 e. $\AA^{-3}$ 


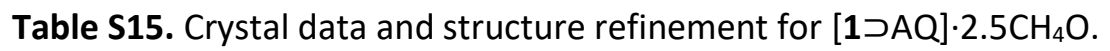

Identification code
Empirical formula
Formula weight
Temperature
Wavelength
Crystal system
Space group
Unit cell dimensions

Volume

$\mathrm{Z}$

Density (calculated)

Absorption coefficient

$\mathrm{F}(000)$

Crystal size

Theta range for data collection

Index ranges

Reflections collected

Independent reflections

Completeness to theta $=67.000^{\circ}$

Absorption correction

Max. and min. transmission

Refinement method

Data / restraints / parameters

Goodness-of-fit on $\mathrm{F}^{2}$

Final $\mathrm{R}$ indices [I>2sigma(I)]

$\mathrm{R}$ indices (all data)

Extinction coefficient

Largest diff. peak and hole rf23ra

C96.50 H96 O8.50

1391.73

100(2) K

$1.54184 \AA$

Triclinic

P-1

$\mathrm{a}=19.335(10) \AA$

$\alpha=117.13(5)^{\circ}$.

$\mathrm{b}=20.831(11) \AA$

$\beta=97.39(5)^{\circ}$.

$\mathrm{c}=21.770(12) \AA$

$\gamma=90.80(5)^{\circ}$.

7712(8) $\AA^{3}$

4

$1.199 \mathrm{Mg} / \mathrm{m}^{3}$

$0.587 \mathrm{~mm}^{-1}$

2972

$0.160 \times 0.050 \times 0.050 \mathrm{~mm}^{3}$

3.462 to $67.000^{\circ}$.

$-21<=\mathrm{h}<=23,-18<=\mathrm{k}<=24,-25<=1<=25$

60971

27037 [R(int) $=0.1548]$

$98.4 \%$

Analytical

0.975 and 0.936

Full-matrix least-squares on $\mathrm{F}^{2}$

27037 / 12 / 1829

1.003

$\mathrm{R} 1=0.1163, w \mathrm{R} 2=0.2483$

$\mathrm{R} 1=0.2597, \mathrm{wR} 2=0.3428$

$\mathrm{n} / \mathrm{a}$

0.700 and -0.388 e. $\AA^{-3}$ 
NMR Spectra 


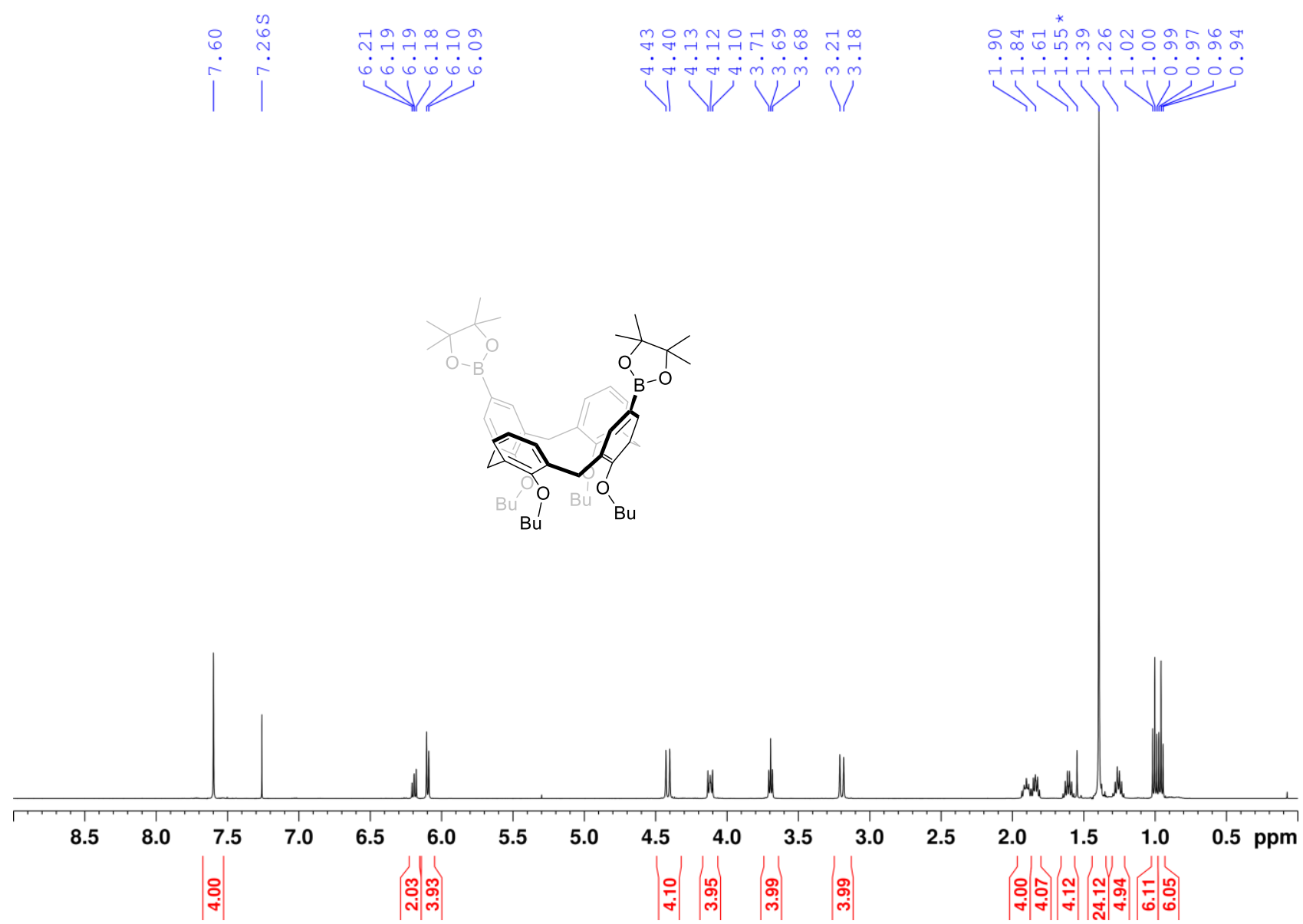

Figure S42. ${ }^{1} \mathrm{H}$ NMR spectrum of $\mathbf{2} \mathbf{b}(500 \mathrm{MHz}$, chloroform- $d$, $300 \mathrm{~K})$.

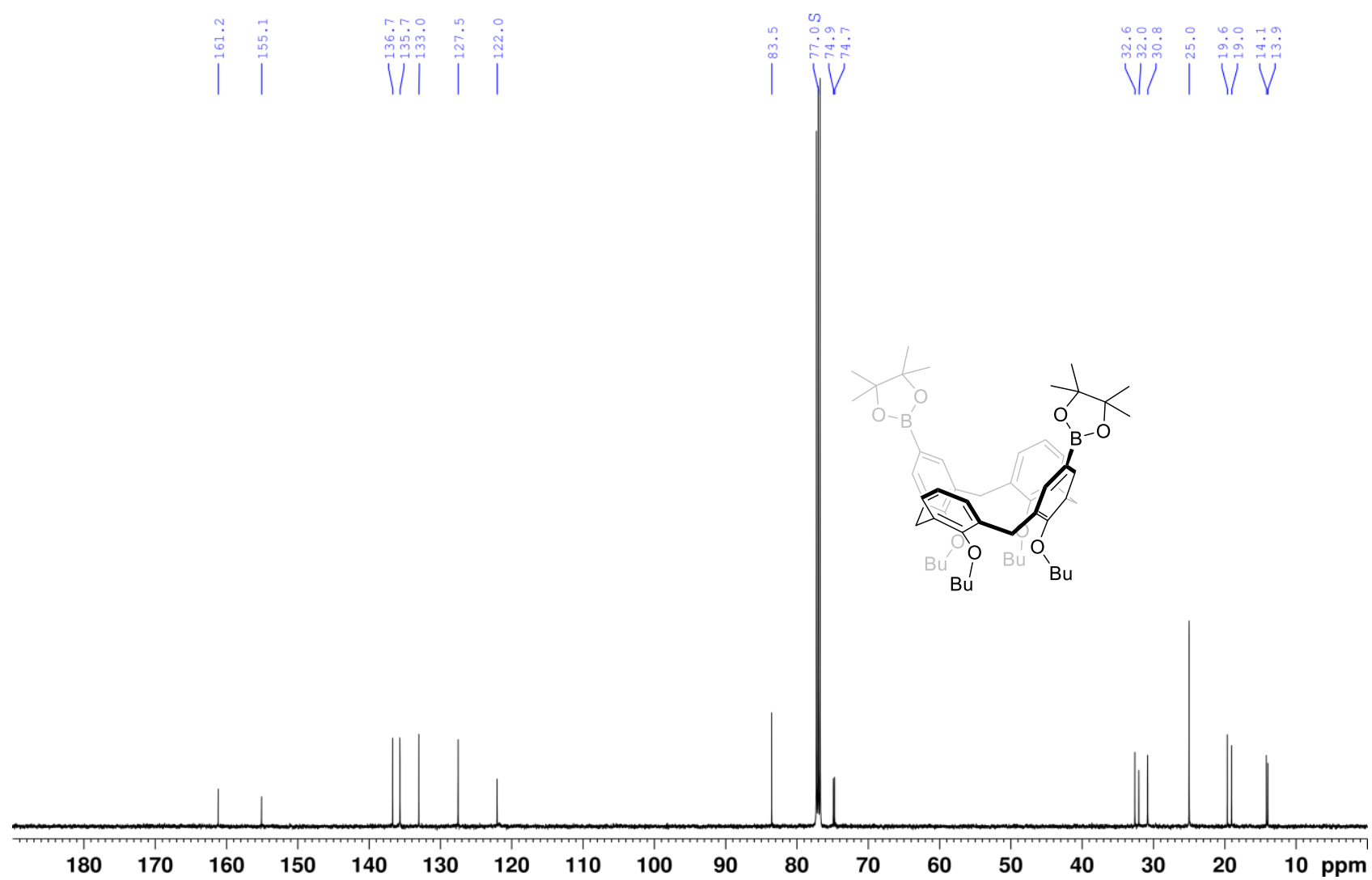

Figure S43. ${ }^{13} \mathrm{C}$ NMR spectrum of $\mathbf{2 b}(125 \mathrm{MHz}$, chloroform-d , $300 \mathrm{~K})$. 


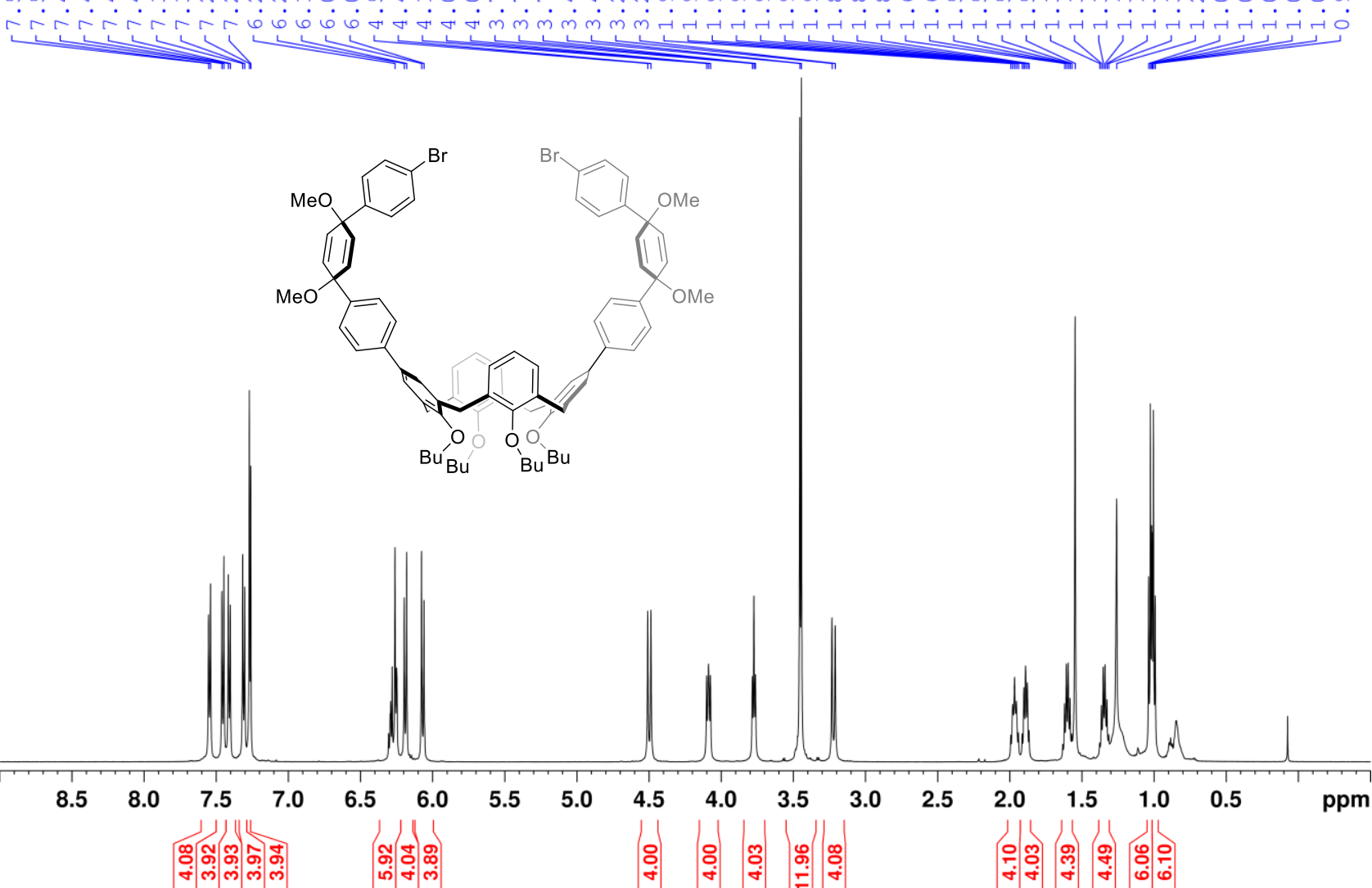

Figure S44. ${ }^{1} \mathrm{H}$ NMR spectrum of 4 (600 MHz, chloroform- $d$, $300 \mathrm{~K}$ ).

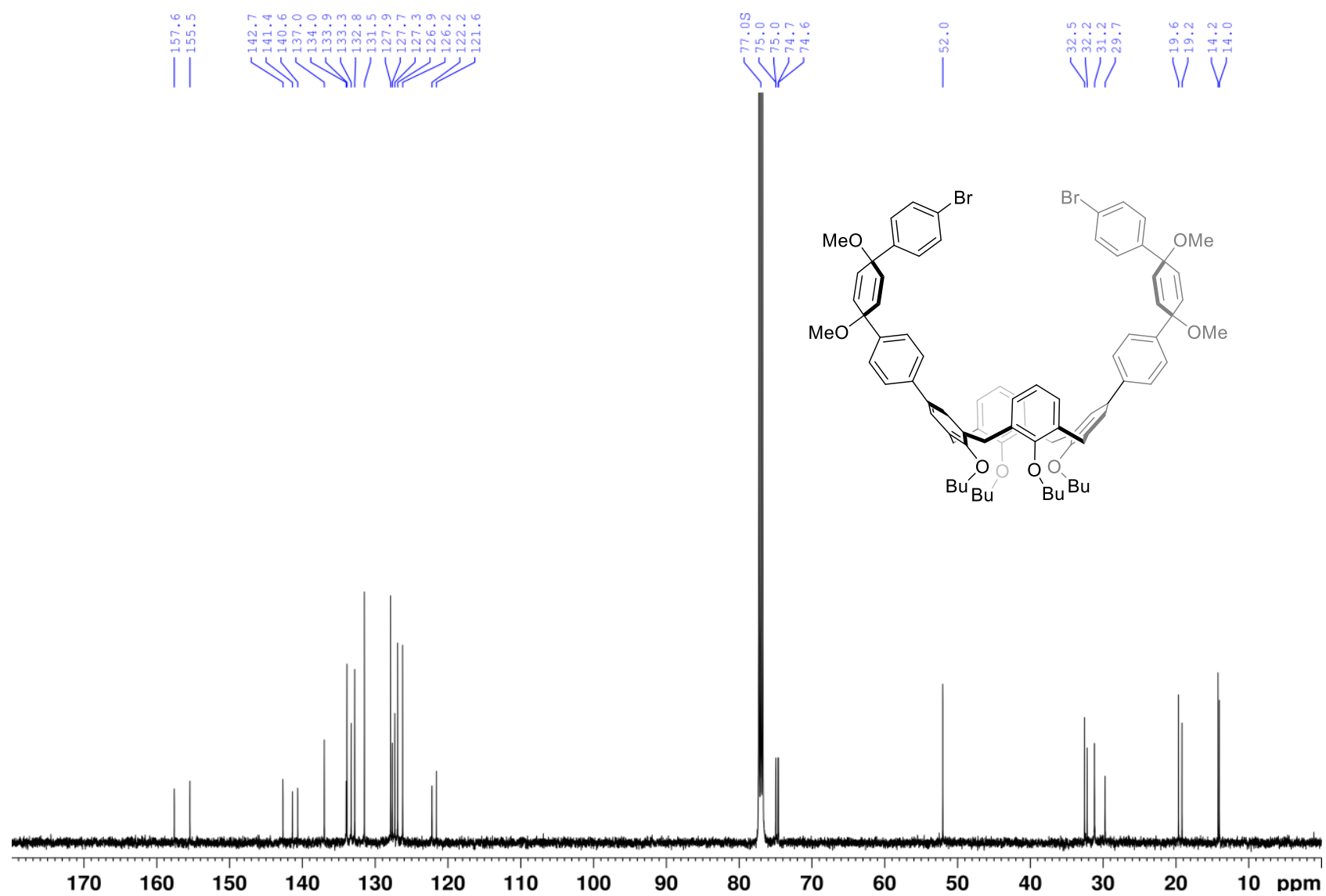

Figure S45. ${ }^{13} \mathrm{C}$ NMR spectrum of 4 (125 MHz, chloroform-d , $300 \mathrm{~K}$ ). 


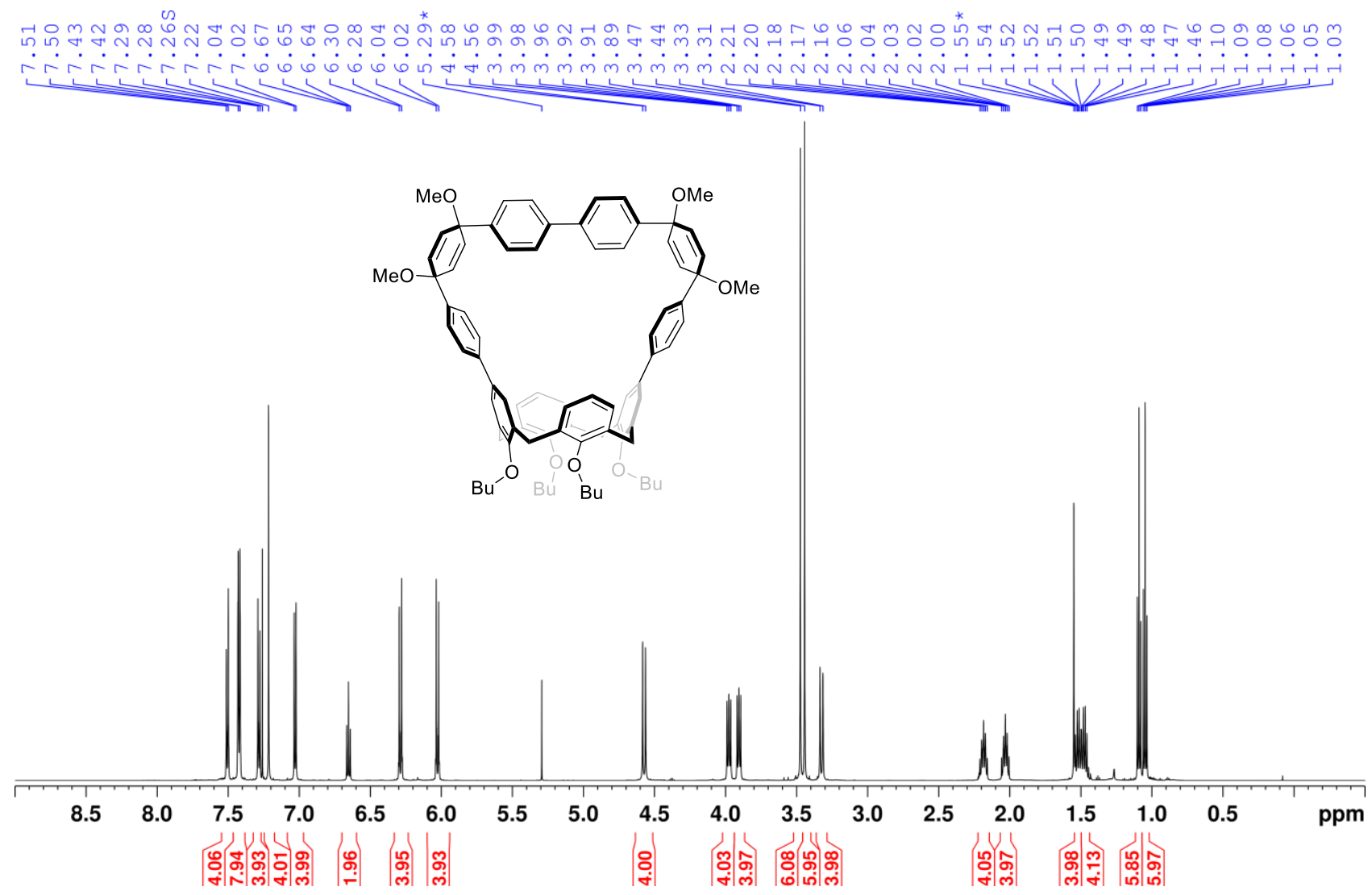

Figure S46. ${ }^{1} \mathrm{H}$ NMR spectrum of 5 (600 MHz, chloroform-d , $\left.300 \mathrm{~K}\right)$.

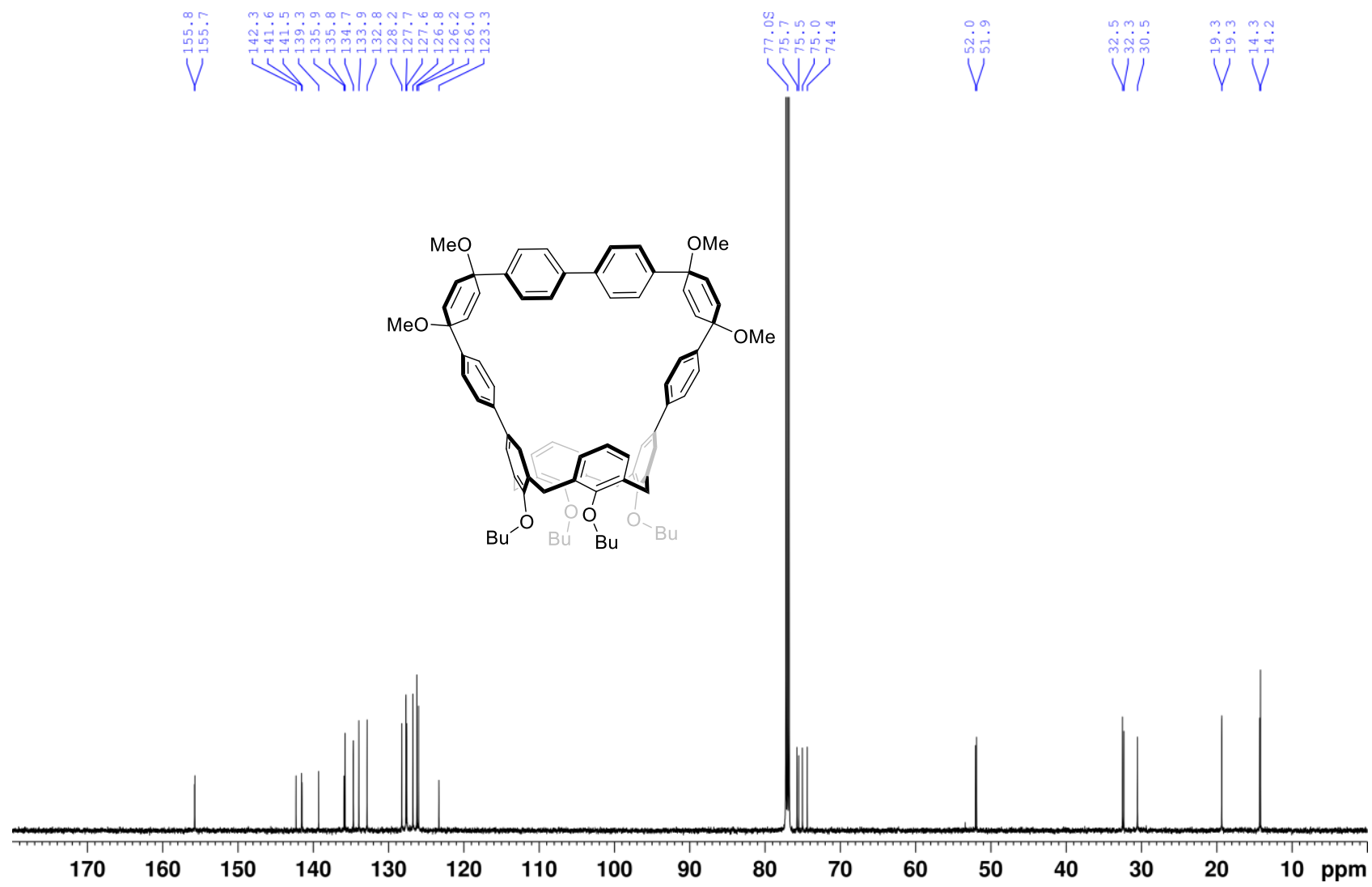

Figure S47. ${ }^{13} \mathrm{C}$ NMR spectrum of 5 (151 MHz, chloroform-d , $300 \mathrm{~K}$ ). 


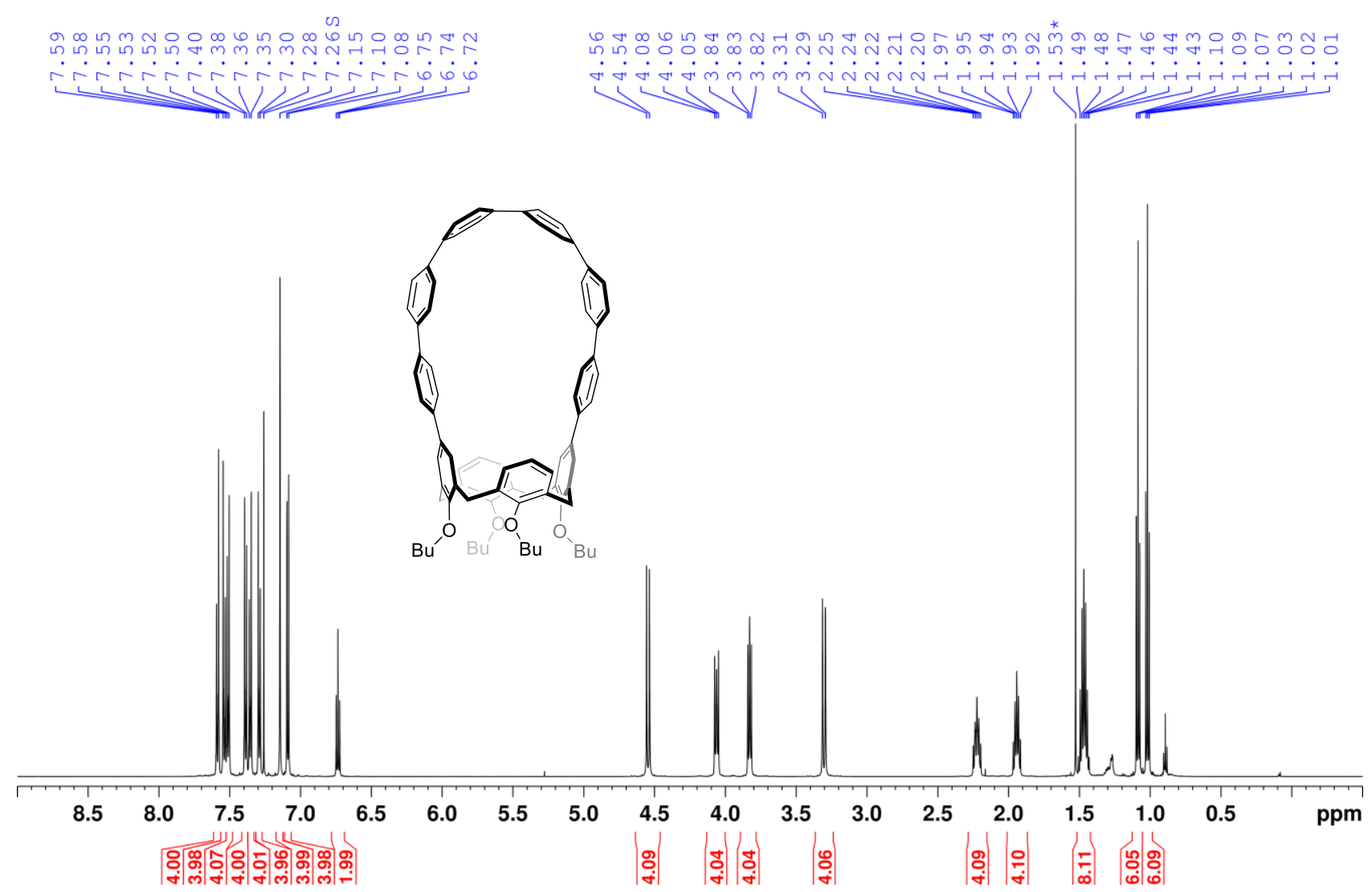

Figure S48. ${ }^{1} \mathrm{H}$ NMR spectrum of 1 (600 MHz, chloroform- $d$, $300 \mathrm{~K}$ ).

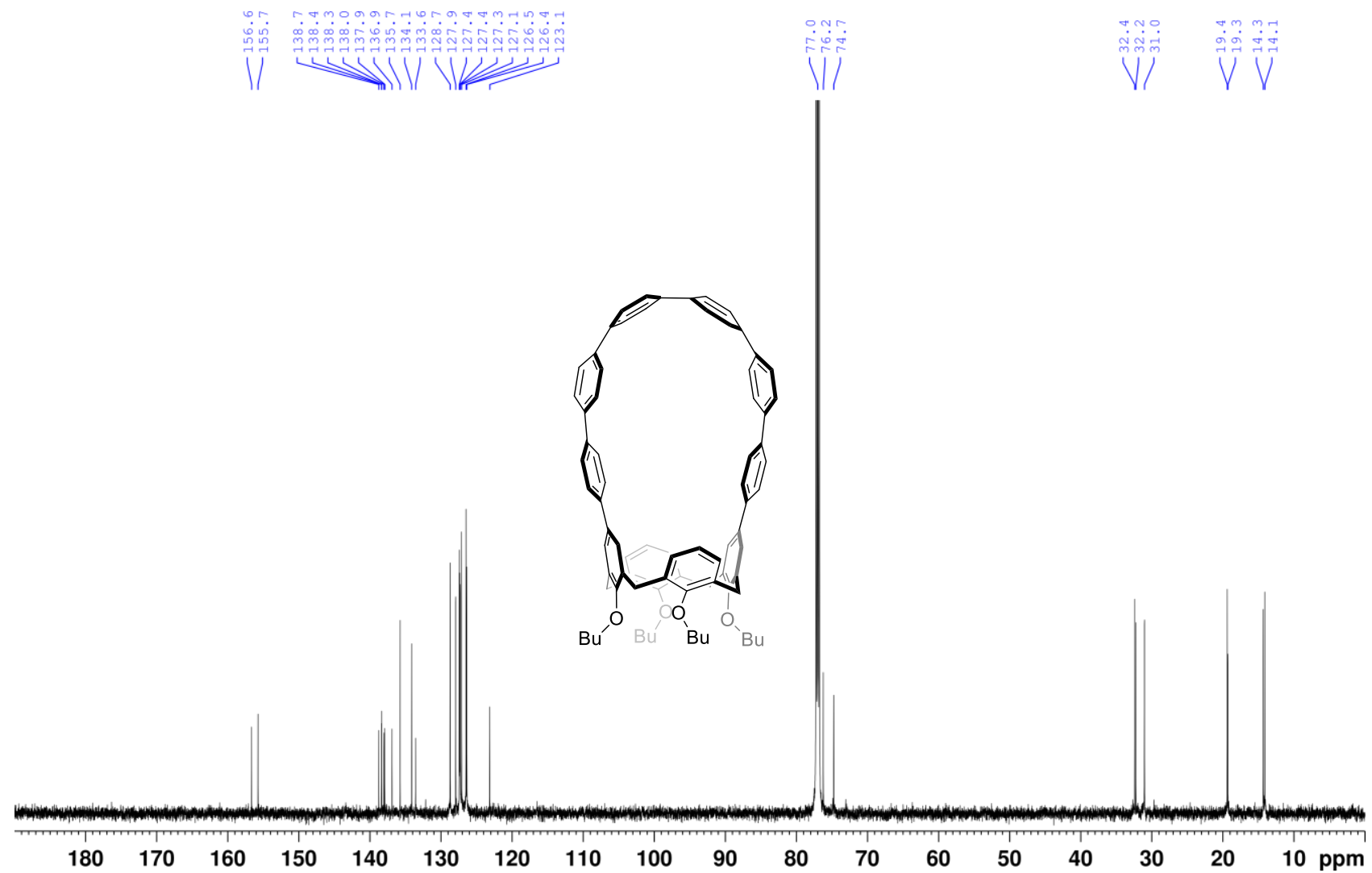

Figure S49. ${ }^{13} \mathrm{C}$ NMR spectrum of 1 (151 MHz, chloroform- $d, 300 \mathrm{~K}$ ). 
Mass Spectra 


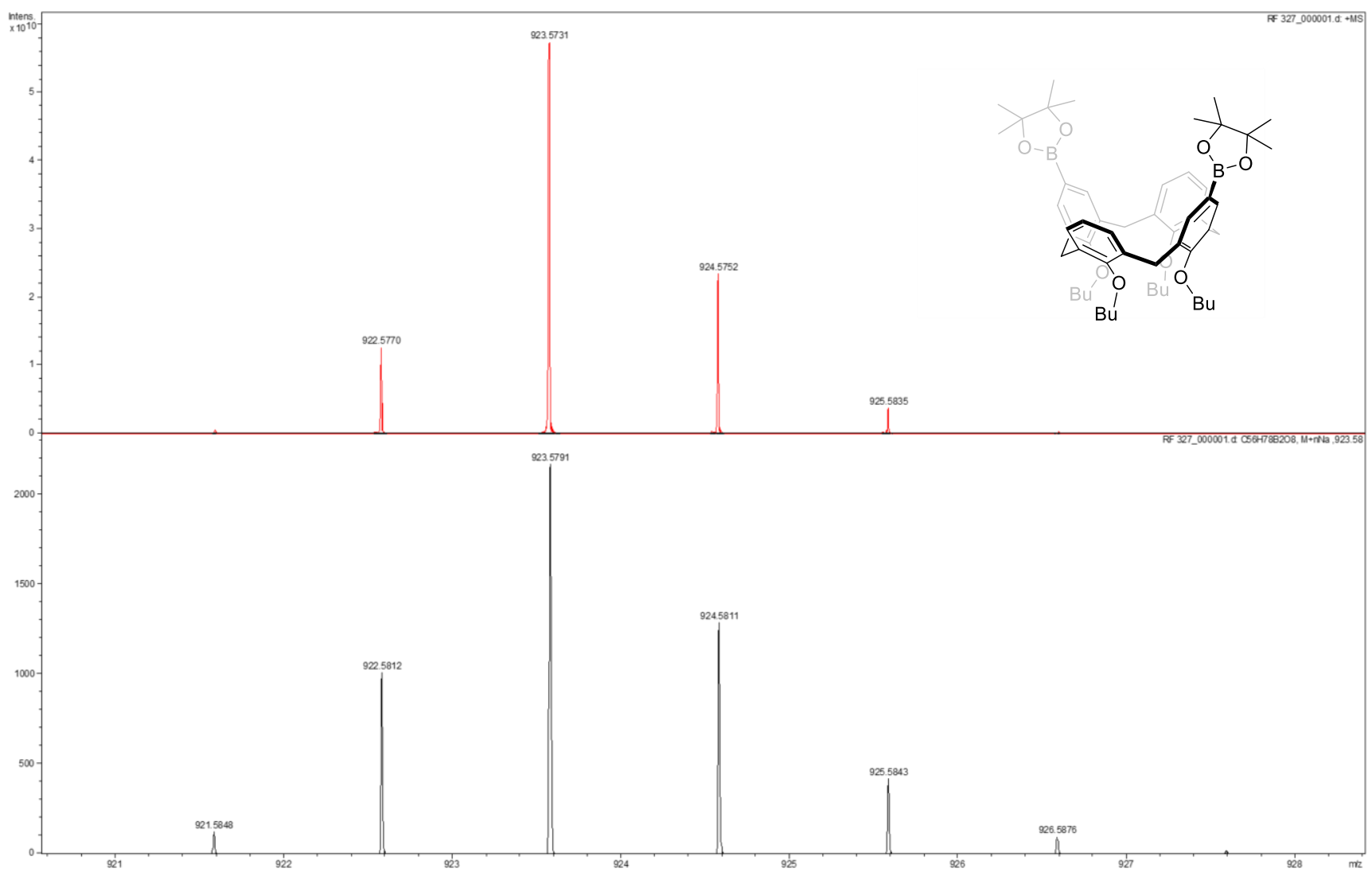

Figure S50. High resolution mass spectrum of ab (ESI-TOF, top: experimental, bottom: simulated).

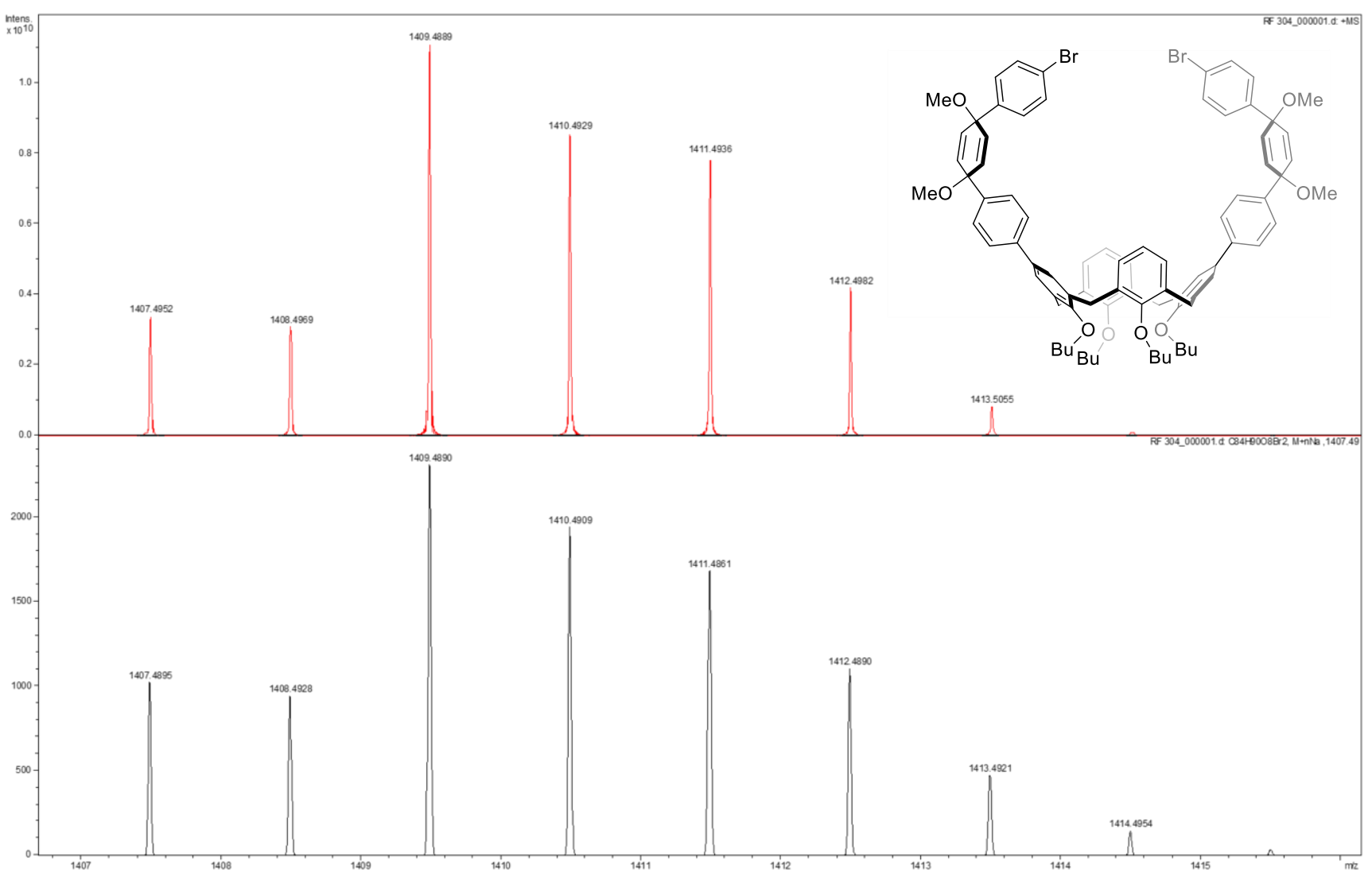

Figure S51. High resolution mass spectrum of 4 (ESI-TOF, top: experimental, bottom: simulated).

S72 


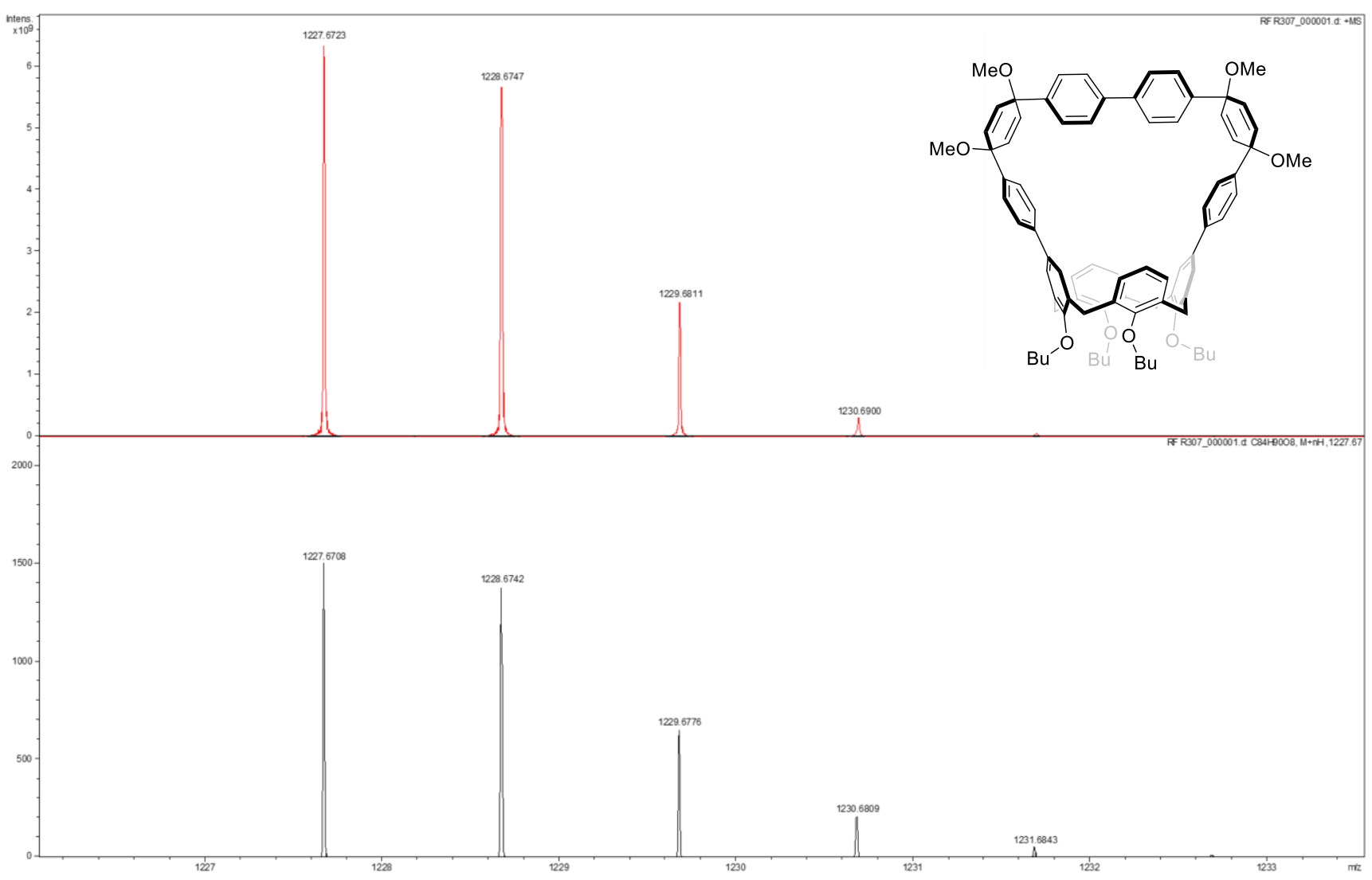

Figure S52. High resolution mass spectrum of 4 (ESI-TOF, top: experimental, bottom: simulated).

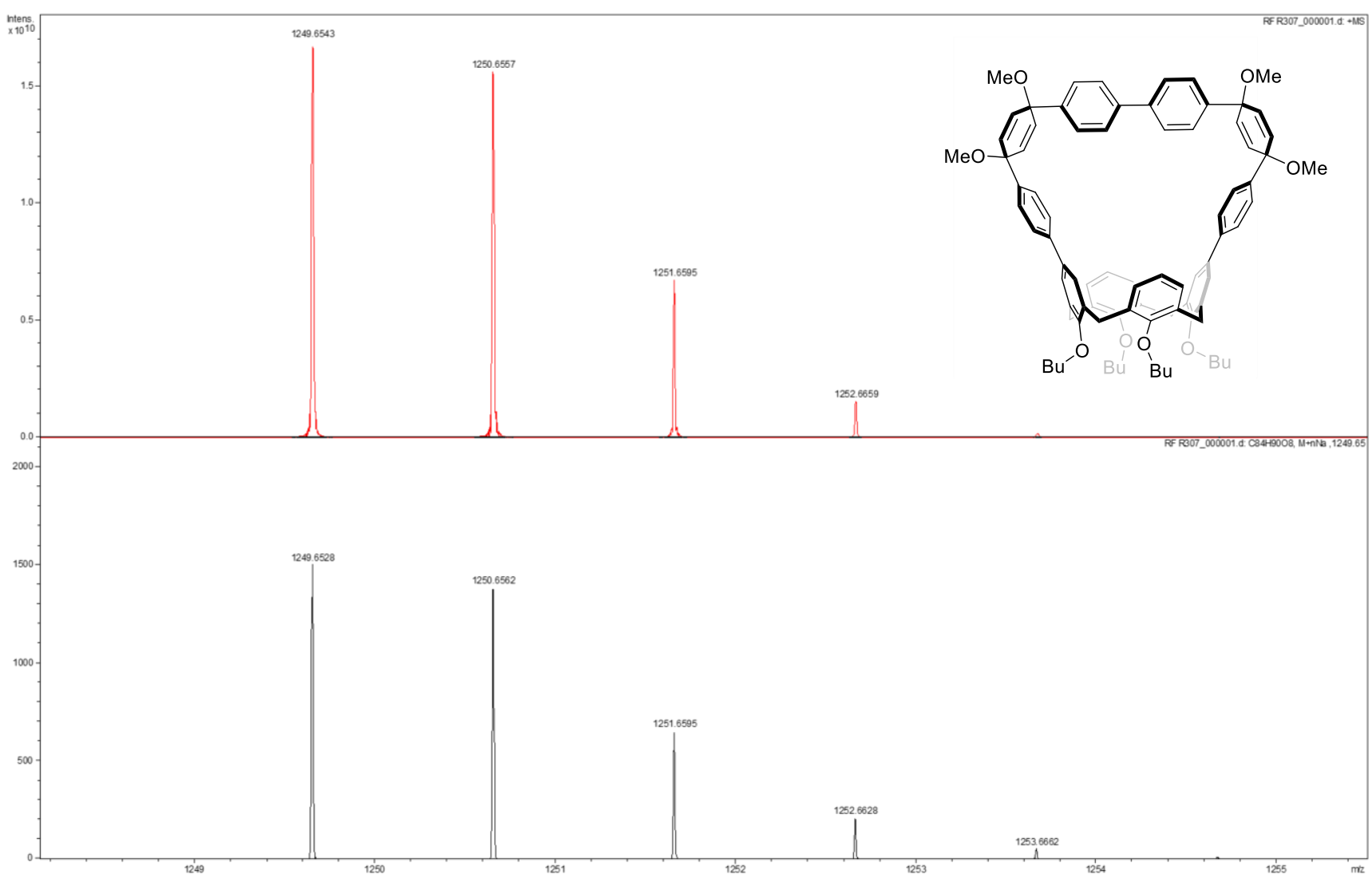

Figure S53. High resolution mass spectrum of 4 (ESI-TOF, top: experimental, bottom: simulated). 


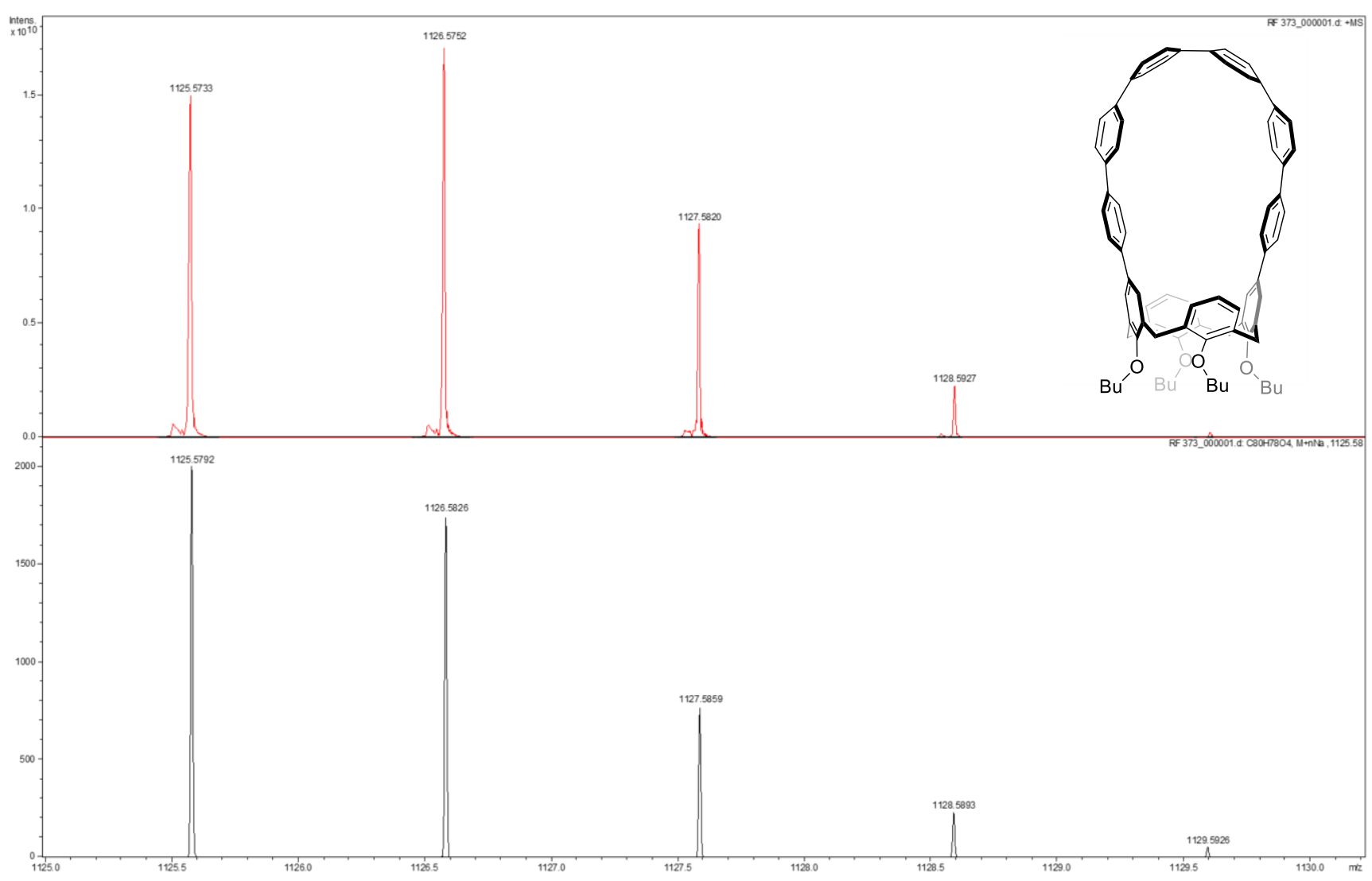

Figure S54. High resolution mass spectrum of 1 (ESI-TOF, top: experimental, bottom: simulated). 
References 
(1) Iqbal, M.; Gutsche, C. D. P-Tert-BUTYLCALIX[4]ARENE. Org. Synth. 1990, 68, 234. https://doi.org/10.15227/orgsyn.068.0234.

(2) Lee, J. H.; Kim, C.; Jung, J. H. Control of the Rheological Properties of Clay Nanosheet Hydrogels with a Guanidinium-Attached Calix[4]Arene Binder. Chem. Commun. 2015, 51 (82), 1518415187. https://doi.org/10.1039/C5CC06024A.

(3) Bonini, C.; Chiummiento, L.; Funicello, M.; Lopardo, M. T.; Lupattelli, P.; Laurita, A.; Cornia, A. Novel Chiral Calix[4]Arenes by Direct Asymmetric Epoxidation Reaction. J. Org. Chem. 2008, 73 (11), 4233-4236. https://doi.org/10.1021/jo800301m.

(4) Guillon, J.; Leger, J.-M.; Dapremont, C.; Apollonia Denis, L.; Sonnet, P.; Massip, S.; Jarry, C. First Synthesis of 1,3-Alternate 25,27-Dialkyloxy-5,17-Diarylcalix[4]Arenes-Crown-6 as New Cesium Selective Extractants by Suzuki Cross-Coupling Reaction. Supramolecular Chemistry 2004, 16 (5), 319-329. https://doi.org/10.1080/1061027042000213038.

(5) Elaieb, F.; Sameni, S.; Awada, M.; Jeunesse, C.; Matt, D.; Toupet, L.; Harrowfield, J.; Takeuchi, D.; Takano, S. Metallated Container Molecules: A Capsular Nickel Catalyst for Enhanced Butadiene Polymerisation. Eur. J. Inorg. Chem. 2019, 2019 (43), 4690-4694. https://doi.org/10.1002/ejic.201901074.

(6) Thordarson, P. Determining Association Constants from Titration Experiments in Supramolecular Chemistry. Chem. Soc. Rev. 2011, 40 (3), 1305-1323. https://doi.org/10.1039/C0CS00062K.

(7) Hibbert, D. B.; Thordarson, P. The Death of the Job Plot, Transparency, Open Science and Online Tools, Uncertainty Estimation Methods and Other Developments in Supramolecular Chemistry Data Analysis. Chem. Commun. 2016, 52 (87), 12792-12805. https://doi.org/10.1039/C6CC03888C.

(8) Xiao, Y.; Chu, L.; Sanakis, Y.; Liu, P. Revisiting the IspH Catalytic System in the Deoxyxylulose Phosphate Pathway: Achieving High Activity. J. Am. Chem. Soc. 2009, 131 (29), 9931-9933. https://doi.org/10.1021/ja903778d.

(9) Ischay, M. A.; Lu, Z.; Yoon, T. P. [2+2] Cycloadditions by Oxidative Visible Light Photocatalysis. J. Am. Chem. Soc. 2010, 132 (25), 8572-8574. https://doi.org/10.1021/ja103934y.

(10) Feinberg, A. M.; Davydovich, O.; Lloyd, E. M.; Ivanoff, D. G.; Shiang, B.; Sottos, N. R.; Moore, J. S. Triggered Transience of Plastic Materials by a Single Electron Transfer Mechanism. ACS Cent. Sci. 2020, 6 (2), 266-273. https://doi.org/10.1021/acscentsci.9b01237.

(11) Bindfit Http://Supramolecular.Org.

(12) Pracht, P.; Bohle, F.; Grimme, S. Automated Exploration of the Low-Energy Chemical Space with Fast Quantum Chemical Methods. Phys. Chem. Chem. Phys. 2020. https://doi.org/10.1039/C9CP06869D.

(13) Grimme, S.; Bannwarth, C.; Shushkov, P. A Robust and Accurate Tight-Binding Quantum Chemical Method for Structures, Vibrational Frequencies, and Noncovalent Interactions of Large Molecular Systems Parametrized for All Spd-Block Elements $(Z=1-86)$. J. Chem. Theory Comput. 2017, 13 (5), 1989-2009. https://doi.org/10.1021/acs.jctc.7b00118.

(14) Bannwarth, C.; Ehlert, S.; Grimme, S. GFN2-XTB-An Accurate and Broadly Parametrized SelfConsistent Tight-Binding Quantum Chemical Method with Multipole Electrostatics and DensityDependent Dispersion Contributions. Journal of Chemical Theory and Computation 2019, 15 (3), 1652-1671. https://doi.org/10.1021/acs.jctc.8b01176.

(15) Frisch, M. J.; Trucks, G. W.; Schlegel, H. B.; Scuseria, G. E.; Robb, M. A.; Cheeseman, J. R.; Scalmani, G.; Barone, V.; Petersson, G. A.; Nakatsuji, H.; Li, X.; Caricato, M.; Izmaylov, A. F.; Zheng, G.; Sonnenberg, J. L.; Hada, M.; Ehara, M.; Toyota, K.; Fukuda, R.; Hasegawa, J.; Ishida, M.; Nakajima, T.; Honda, Y.; Kitao, O.; Nakai, H.; Vreven, T.; Montgomery, Jr., J. A.; Peralta, J. E.; Ogliaro, F.; Bearpark, M.; Heyd, J. J.; Brothers, E.; Kudin, K. N.; Staroverov, V. N.; Kobayashi, R.; Normand, J.; Raghavachari, K.; Rendell, A.; Burant, J. C.; Iyengar, S. S.; Tomasi, J.; Cossi, M.; Millam, J. M.; Klene, M.; Adamo, C.; Gomperts, R.; Stratmann, R. E.; Yazyev, O.; Austin, A. J.; Cammi, R.; Pomelli, C.; Ochterski, J. W.; Martin, R. L.; Morokuma, K.; Zakrzewski, V. G.; Voth, G. 
A.; Salvador, P.; Dannenberg, J. J.; Dapprich, S.; Daniels, A. D.; Farkas, O.; Foresman, J. B.; Fox, D. J. Gaussian 16, Revision B.01; Wallingford CT, 2016.

(16) Becke, A. D. Density-Functional Exchange-Energy Approximation with Correct Asymptotic Behavior. Phys. Rev., A 1988, 38 (6), 3098-3100.

(17) Becke, A. D. Density-functional Thermochemistry. III. The Role of Exact Exchange. J. Chem. Phys. 1993, 98 (7), 5648-5652. https://doi.org/10.1063/1.464913.

(18) Lee, C.; Yang, W.; Parr, R. G. Development of the Colle-Salvetti Correlation-Energy Formula into a Functional of the Electron Density. Phys. Rev. B 1988, 37 (2), 785-789. https://doi.org/10.1103/PhysRevB.37.785.

(19) Grimme, S.; Ehrlich, S.; Goerigk, L. Effect of the Damping Function in Dispersion Corrected Density Functional Theory. Journal of Computational Chemistry 2011, 32 (7), 1456-1465. https://doi.org/10.1002/jcc.21759. 